Historic, Archive Document

Do not assume content reflects current scientific knowledge, policies, or practices. 



\section{QUALTIY SEDDS}
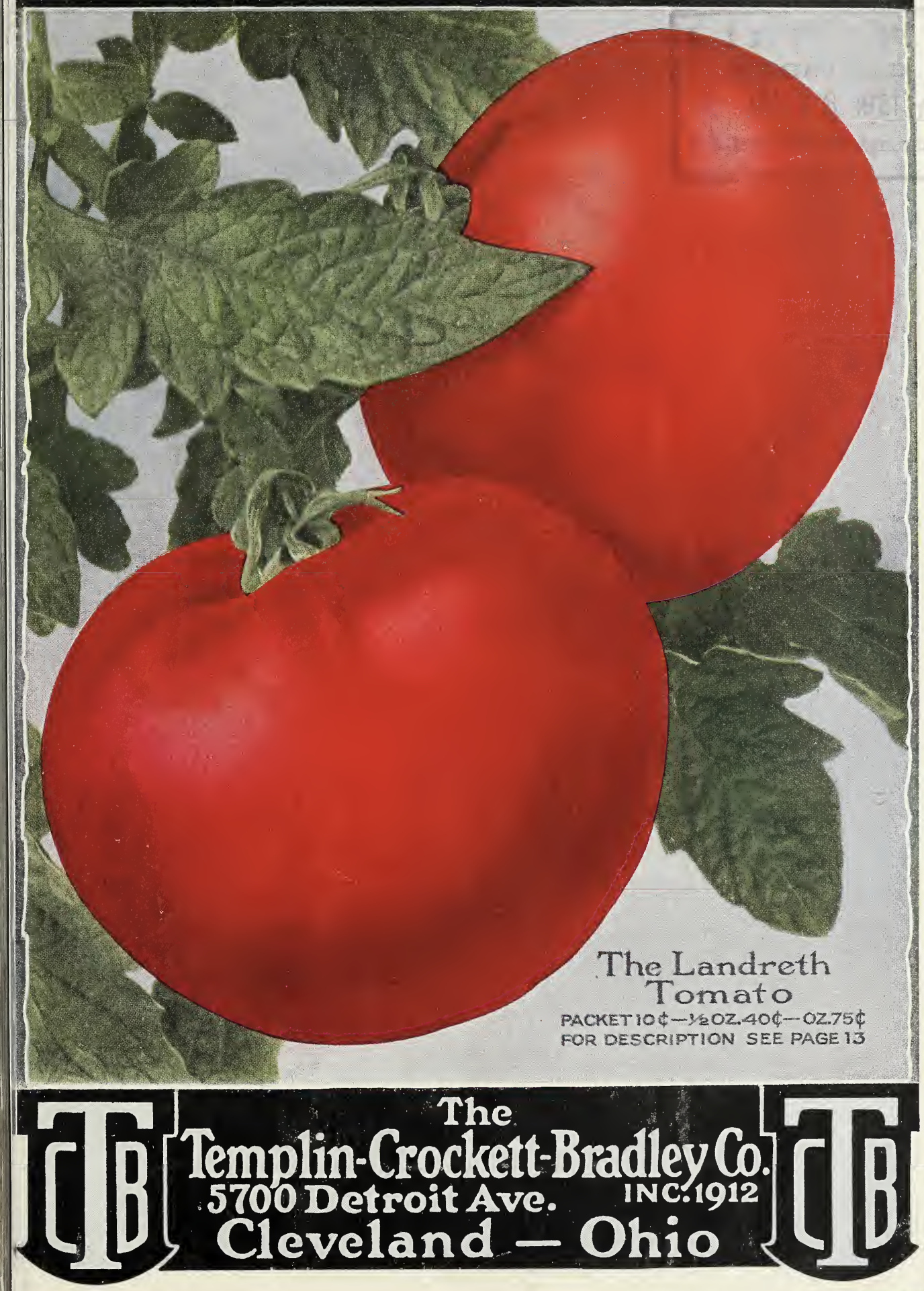


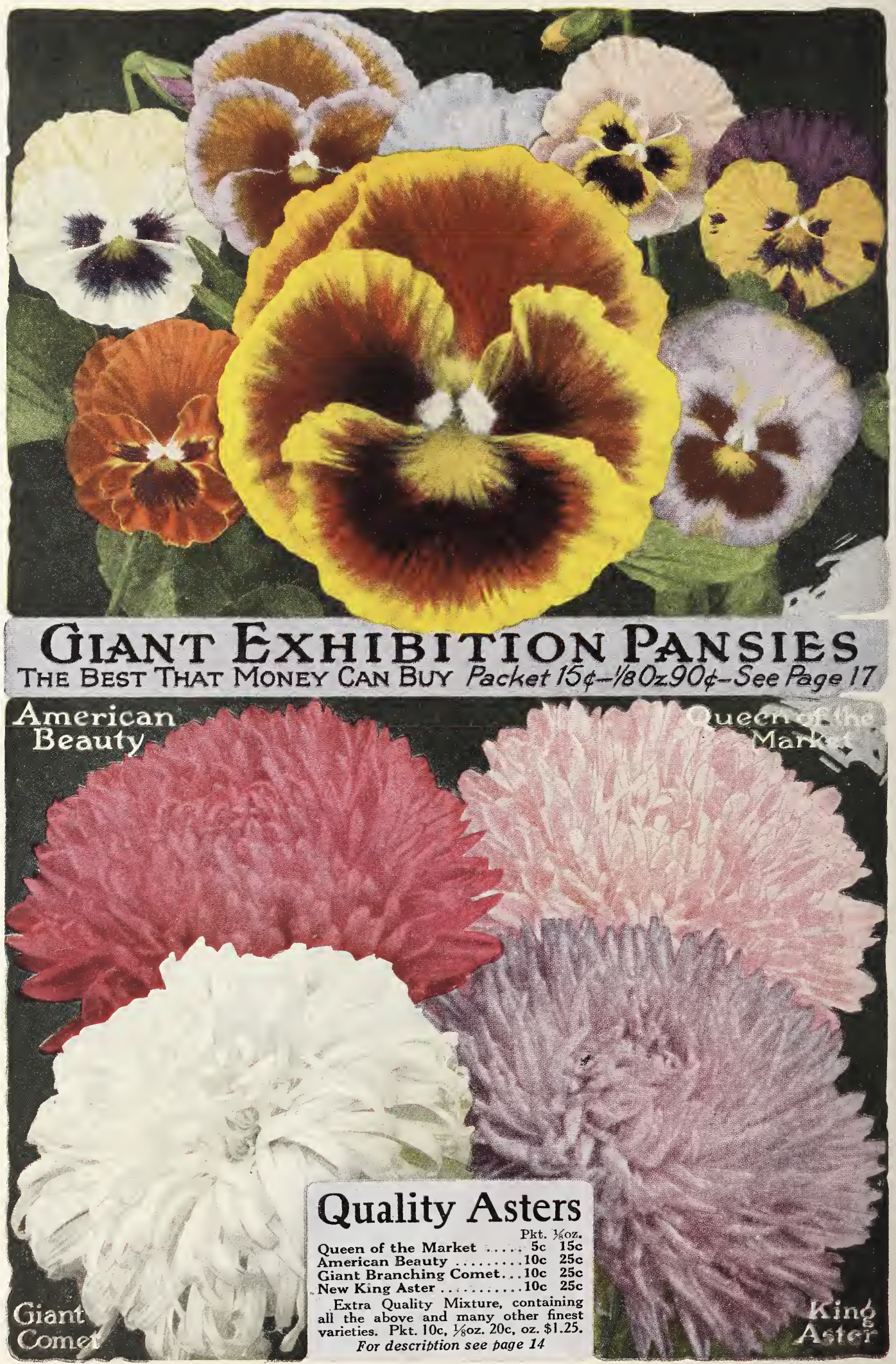




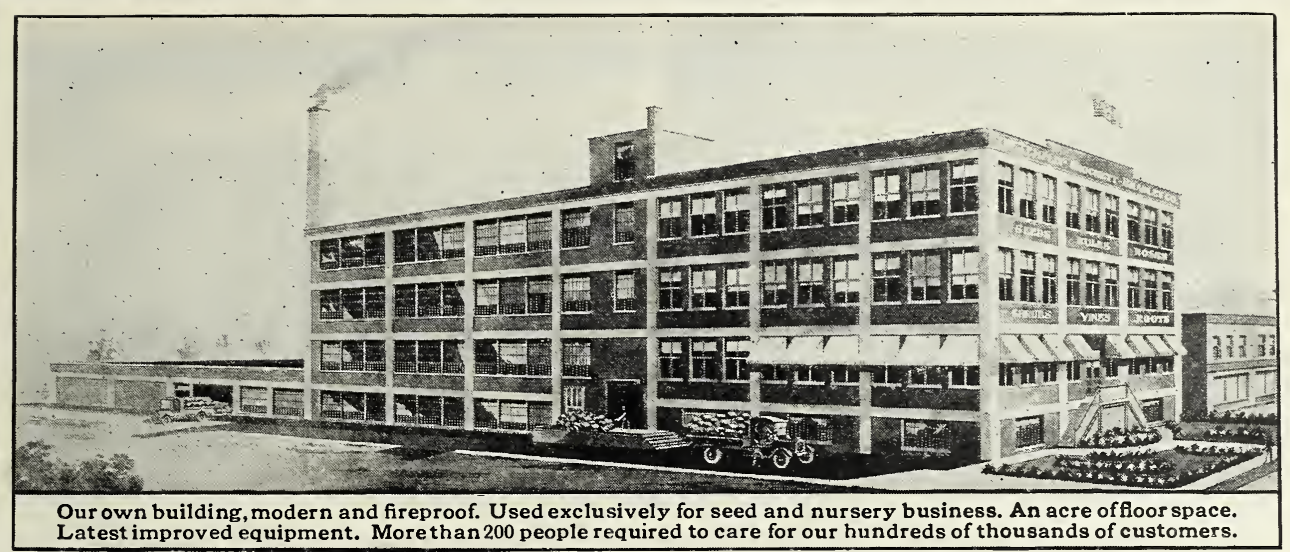

\section{$\mathscr{M r}$. and $\mathscr{M r s .}$ Gardener, Anywhere, U.S.A.}

Season of 1921.

If we were to name this catalog, probably no better name could be given than, "Seed Buying Made Easy." In the lifetime of experience put into this little volume, there are many things of value to you. Do you recognize them? Let us mention a few.

A Complete List Either by name or description, you will find here the best varieties of lesser value have been omitted. Therefore, this catalog lists only recognized standard varieties.

Type, Maturity, Quality Every requirement you may have for these three important points are carefully thought of in our selection of the varieties offered you here. We know what you will ask for and have listed only such kinds. And the Quality is right.

A Real Order Blank The order blank which goes with this catalog is almost a catalog A Real Order Blank in itself. Every variety bears the same number as in the catalog and in the same rotation. No difficult horticultural and botanical names for you to spell. Just fill in the figures to tell us how many packets you wish and fill in the value so that you will know how much money to send with your order. You will see how simple it is when you try it.

Seed Knowledge Mr. Templin's knowledge of seeds, bulbs and shrubs, gained in more than growers with whom we have contracted for our seeds for years and years, are located in 28 of the 48 states and in 11 for eign countries. They are all experts, having selected their location carefully, with the one idea of being able to supply us with seeds which will give our customers absolute satisfaction. This combined knowledge is important to you because neither growing or handling of seeds is an experiment with us or our grcwers.

Prices Include Delivery When you send us your order, you do not have to figure out tra money you will have to send with your order to pay carrying charges. Every price quoted in this catalog includes delivery to your nearest express or post office.

Order Early There is an advantage to you in sending us your order early. Then you will " $B e$ Order Early Ready When the Nice Days Come." If you will send in your order now while you think of it, we will ship the seeds at once. Any bulbs, shrubs or roots will be kept here until danger of freezing has passed and then that part of your order will be shipped in plenty of time for planting. We suggest doing this because we have very good facilities for keeping the stock here. And it will be in better condition when planting time does come.

Use our seeds this season and we will guarantee you satisfaction or the return of the money you paid us for any item which you think is not satisfactory.

Yours for a better garden,

The Templin-Crockett-Bradley Company 

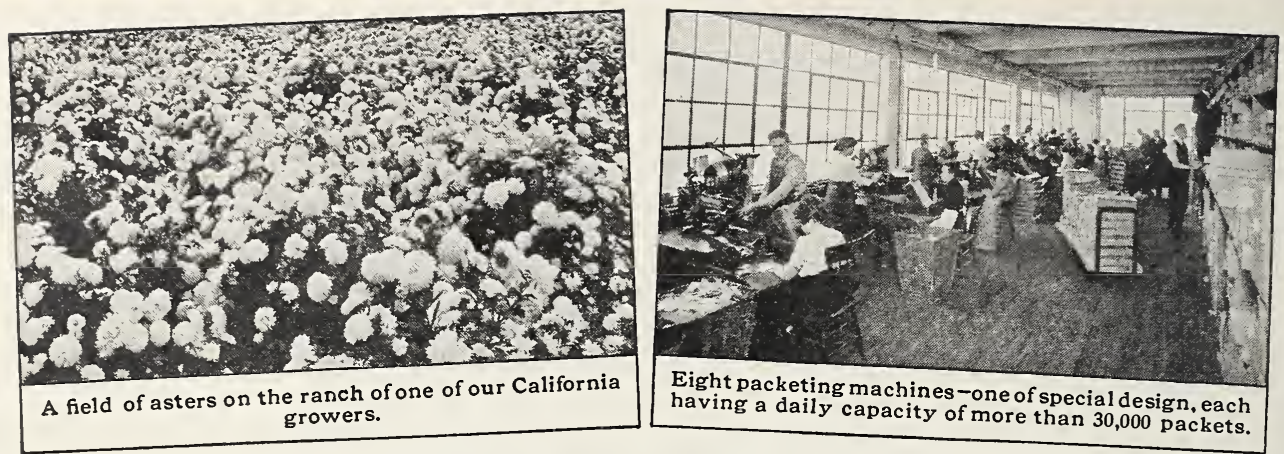

\section{Visitors Are Welcome}

$V$ isitors show such a keen interest in the methods we use in filling seed, bulb and shrub orders that we naturally believe you, who have not had the opportunity of seeing for yourself, would like to know how your orders will be handled.

I

$\mathrm{N}$ a seed incubator, designed by Mr. Templin, tests of all varieties are made as rapidly as the seeds come in from our growers. These germination tests in this electrical device are made to prove to our satisfaction that the seeds are up to the standard.

Immediately following the tests in October, the seed packeting machines are put into operation. The machine opens the packet, pours in a definite measure of seed, applies hot glue, folds the flap and holds it just long enough to insure sealing. Right here it will be interesting to note that in the fifteen years we have been using these machines, we have never received a single complaint that the quantity of seed in any packet was less than we stated in our catalog. As soon as a full assortment of all varieties has been packeted, the order filling cases are stocked, ready for orders.

A definite system is followed in the handling of all orders from the time they arrive in the daily mail until the goods have been shipped. This is necessary as during the busy season we receive each day an average of more than seven thousand individual orders. A specially designed auditing machine gives each order a separate number, prints the form of remittance and amount and date. Card records are then made, following which a force of thirty trained

examiners check over all orders for mistakes. Right here is a good place to tell you that last season more than one hundred orders were received which bore neither name nor address of customer. So please remember to write your name and address on the order blank.

From the office, seed orders are sent to the seed order filling department and are filled within a very few days of arrival. The shrubbery order is held for filling in the spring after danger of freezing has passed, so that the more perishable bulbs and shrubs will arive at your home in good condition. All single items and collections in this latter department are carefully labeled and are packed to stand several days travel between our office and your home.

The mailing department handles from four to five tons of parcel post packages each day. Government Postal Clerks are provided in our building to cancel stamps and route packages. The great mail sacks are sent direct to the mail trains as they do not have to be rehandled in the Cleve-

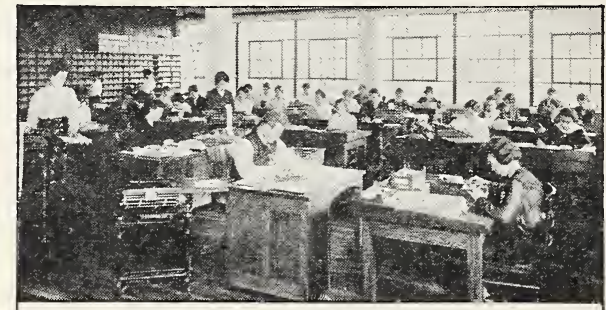

Our auditing department handles an average of 7000 individual orders every day. land Post Office. This often means a gain of several days.

There is much more that we could tell if space permitted. All of it would point still more clearly to you why and how we are equipped to handle your orders to your entire satisfaction. If you are ever in Cleveland, you will be welcome to visit our plant.
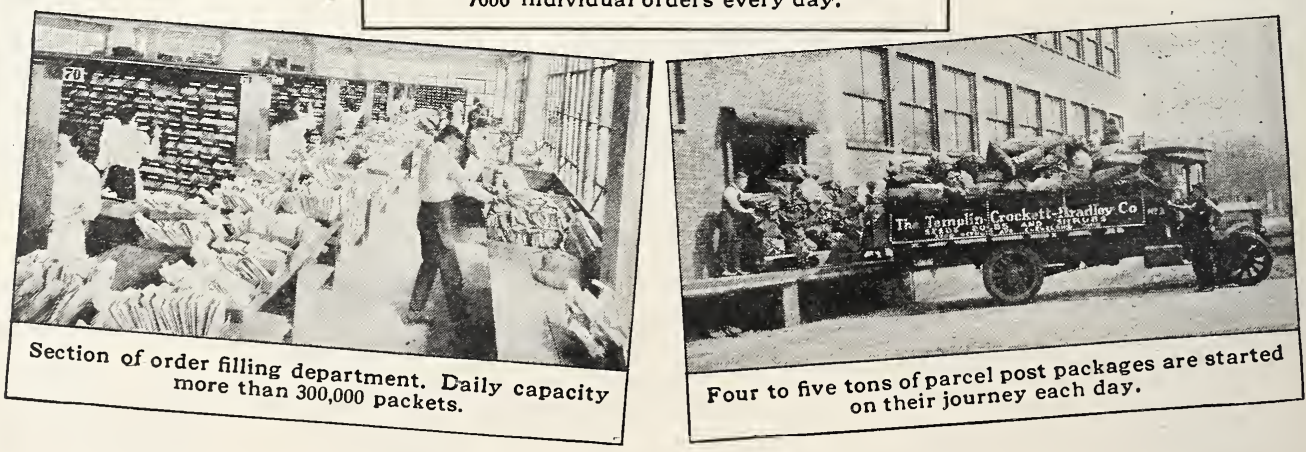
Four to five tons of parcel post packages 


\section{\$1 - Home Garden Collection - \$1 Big Values for Your $\mathscr{M}$ Money}

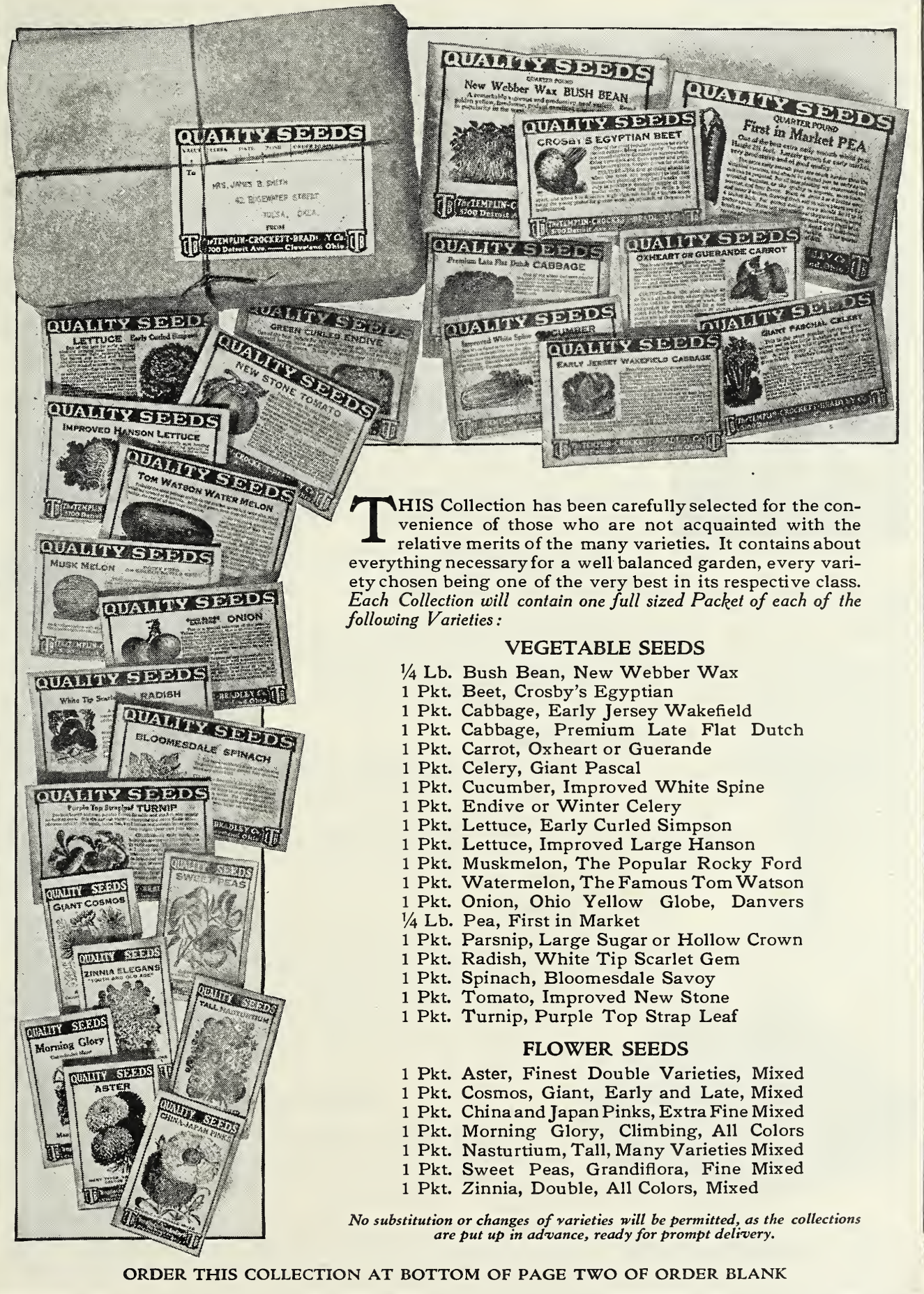




\section{QUALITY VEGETABLE SEEDS}

We have always made it a matter of house policy to list only a few of the most worthy varieties which are in the greatest general demand. These are all certain to give uniform satisfaction. The wisdom of this action has been proven beyond a doubt as we are able not only to greatly reduce the cost of catalogs but also to sell larger quantities of each variety listed, at less expense. This saving is passed on to you in greater values for your money.

Columbian Mammoth White. A very strong-growing variety, producing very large, white,
Asparagus tender stalks, equal in flavor to the green varieties. Pkt. (250 seeds) 3 cts., ounce 10 cts. For
Asparagus Roots, see page 24 .

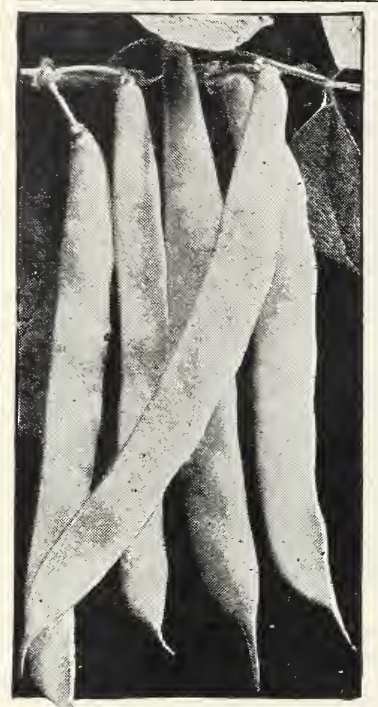

New Webber Wax Beans

\section{Green Pod Bush "Snap" Beans}

Each packet of Beans will contain a full quarter pound. Sufficient to plant 40 to 50 feet of row.

2 Burpee's Stringless Green-Pod One of the most popular of the productive, and always free from strings. Whether for home or market, we know of no variety combining more good qualities. $1 / 4 \mathrm{lb}$. pkg. $12 \mathrm{cts}$., $1 \mathrm{~b} .40 \mathrm{cts}$.

3 Bountiful Best of the flat-podded stringless varieties. Pods $61 / 2$ to 7 inches long, green. Very early, vigorous, hardy and productive. $1 / 41 \mathbf{l b}$. pkg. 12 cts., $1 \mathrm{~b} .40 \mathrm{cts}$. 4 Giant Stringless Green-Pod An exceedingly productive and very nearly round, free from strings. Excellent quality. $1 / 4$ 1b. pkg. 12c, lb. 40 c.

5 Thousand-to-One The popular old Refugee. Wonderfully productive. Main quality. Sure to please. $1 / 4 \mathbf{1 b}$. pkg. $10 \mathrm{cts}$., 1 b. 35 cts.

\section{Wax-Pod or "Butter" Bush Beans}

6 Improved Golden Wax Probably the most popular of the wax varieties. less pods of best quality. Seed white, mottled brown. $1 / 4$ 1b. pkg. 10c, 1 b. $35 \mathrm{c}$.

7 Stringless Refugee Wax A splendid new Wax Bean. Vigorous habit. long, thick, fleshy, round, clear yellow and absolutely stringless. 1/4 1 lb. pkg. 12 cts., 1b. 40 cts.

8 Sure Crop Wax $\begin{gathered}\text { A splendid new Wax } \\ \text { Bean, having black }\end{gathered}$ seed and large, flat, thick, stringless pods, 5 to 6 inches long. Vigorous, rust-resisting. Very productive plant. Very desirable. $1 / 4 \mathbf{l b}^{\mathrm{b}}$. pkg. 12 cts., lb. 40 cts.

9 New Webber Wax $\begin{aligned} & \text { We asked our Bean Grower to name what he con- } \\ & \text { sidered the best Wax Bean. His reply was, "Webber }\end{aligned}$ Wax." It is very vigorous, healthy, and wonderfully productive. In our experience it invariably produced fully fifty per cent more than any other Wax variety. Broad, flat. golden yellow pods absolutely free from strings. $1 / 4 \mathrm{lb}$. pkg. $12 \mathrm{cts}$., 1 b. $40 \mathrm{cts}$.

\section{Pole Beans}

10 Kentucky Wonder of old Homestead. The most useful and satisfactory fully prolific; pods very long, in clusters. May be planted with corn. $1 / 4 \mathbf{~ l b . ~ p k g . ~} 12$ cts., 1b. 40 cts.

11 Golden Cluster Wax Probably the best of all the Wax Pod Pole Beans. thick, fleshy and stringless. Shelled Beans pure white. $1 / 4$ lb. pkg. 15 cts., lb. 50 cts.

\section{Lima Beans}

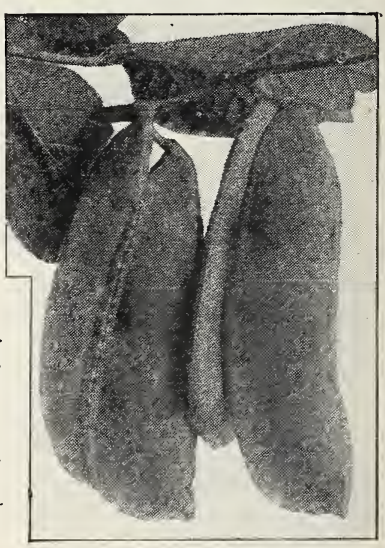

Wonder Bush Lima Bean

12 New Wonder Bush Lima The recognized standard of bush Lima Bean quality - so considered by large, produced in clusters, and maturing in midseason. $1 / 4 \mathrm{lb}$. pkg. 15 cts., 1 b. 50 cts.

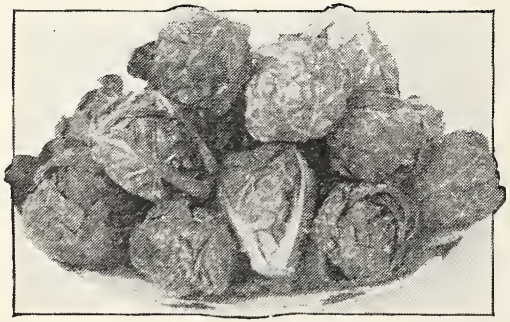

Brussels Sprouts 13 King of the Garden Pole Lima $\begin{gathered}\text { This popular old } \\ \text { standard variety is }\end{gathered}$ one of the best for main crop. The vines produce continually until killed by frost. Pods and beans quite large and of best quality. $1 / 4 \mathbf{l b}$. pkg. 12 cts., 1b. 40 cts.

\section{Shell Beans}

14 Boston White Baking Beans The best white field Commonly called "Pea Bean." Extra early and very prolific, ripening in 80 to 90 days. Grows upright, holding the pods well up from the ground. No other variety equals it in productiveness and quality. $1 / 4 \mathbf{~} \mathbf{l b}$. pkg. 10 cts., 1b. 30 cts.

${ }^{15}$ Brussels Sprouts

Perfection. Belongs to the cabbage family. Small heads of delicious quality are abundantly produced along the stem, the plants growing about two feet high. Cultivate same as late cabbage. Produces its tender little heads from October to December in the North, and throughout the winter in the South. Pkt. 3 cts., $1 / 2$ ounce pkg. 10 cts. 


\section{Beets}

Each packet of Beet seed will plant 20 to 25 feet of row.

16 Crosby's Egyptian One of the earliest and most popular. Roots slightly flattened globe shape; skin blood red; flesh slightly zoned; tons small. A universal favorite. Pkt. 5 cts., large ounce pkg. 10 cts., $1 / 41$ b. 35 cts. 17 Crimson Globe This splendid variety is largely planted for main ways smooth without rootlets tender, and never stringy. Pkt. 5 cts., ounce pkg. 10 cts., $1 / 41$ b. 35 cts.

18 Detroit Dark Red Very popular throughout the West. A big upright tops. Skin dark blood-red; flesh bright crimson, sweet, tender and delicious. Pkt. 5 cts., large ounce pkg. $10 \mathrm{cts.,} 1 / 4$ 1b. $35 \mathrm{cts}$.

19 Eclipse One of the best known. Extra-early, round, smooth, bloodred roots. We offer best imported French-grown seed, a guarMellow 20 Mangel-Wurzel Goshed Mangels. Grows more than half above ground. Easy to harvest. An immense cropper, yielding 30 to 40 ton per acre. Splendid for feeding to poultry and live stock. Keeps well throughout the winter. Ounce pkt. 10 cts., $1 / 4$ 1b. pkg. 25 cts., $1 b .90$ cts.

For Spinach Beet see Swiss Chard, Page 12, Number 125.

It is generally conceded that the best Beet Seed comes from France. As the war is now over we are again using only the best French-grown. The besi is never too good for our trade.

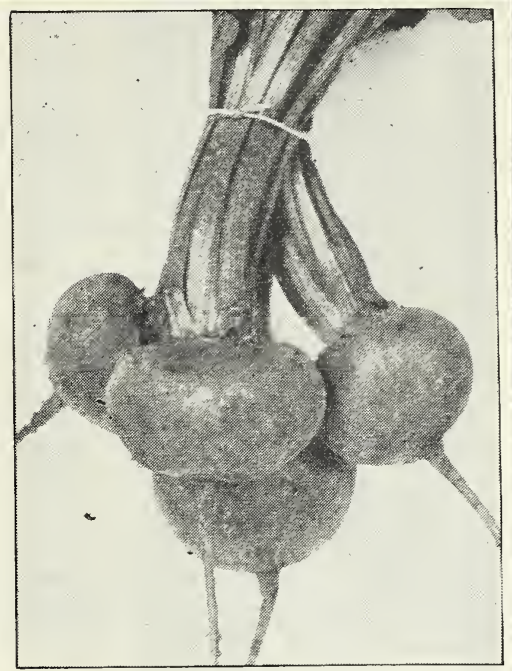

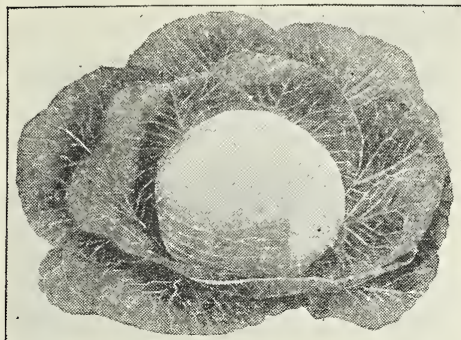

Copenhagen Market

\section{Cabbage Seed}

Each packet of Cabbage seed will grow 300 to 400 plants.

\section{EARLY SUMMER VARIETIES}

21 Early Jersey Wakefield The best-known and most popular solid heads. More largely grown for early market than any other variety. The only variety we would advise planting for extra early, either for home use or market. Pkt. 5 cts., $1 / 2$ ounce pkg. 15 cts., $1 / 41$ b. 90 cts.

22 Copenhagen Market The most popular early Cabbage in larity in America. It is the earliest of the large solid, round head ty pe. Heads average 8 to 10 lbs. each. Very compact in habit, with few outer leaves, which permits closer planting. Earliness, compact growth, large heads and superior quality have made this new cabbage the most popular early variety Our seed is absolutely the best
Danish grown. The illustration is from a photograph. Pkt. 10 cts., $1 / 2$ oz. pkg. 25 cts., $\mathbf{1} / \mathbf{1} \mathbf{1 b}$. $\mathbf{1 . 2 5}$. 23 Glory of Enkhuizen A splendid new medium early variety from Holland, closely the best early round head variety. Some of the finest early cabbage we have ever seen was of this variety. Sure to please the most critical grower. Pkt. 8 cts., $1 / 2$ ounce pkg. 20 cts.

24 Fottler's Brunswick Matures between the early and late main crop varieties. for early winter. An old favorite that is always satisfactory. Pkt. 3 cts., 1/2 oz. pkg. 10 cts.

\section{LATE OR MAIN CROP VARIETIES}

25 Burpee's Surehead Uniformly large, round, flattened heads of the drumhead and of finest quality. Rightly named Surehead, as every plant is sure to produce a nice head. You will make no mistake if you plant Surehead. Pkt. 5 cts., $1 / 2$ oz. pkg. 15 cts., $1 / 41$ b. 90 cts. 26 Premium Late Flat Dutch Probably more largely grown than any other ways reliable. Uniform large flattened heads of excellent quality and a good keeper. Largely grown to supply kraut factories. Pkt. 5 cts., $1 / 2$ ounce pkg. 15 cts., $1 / 41$ b. 90 cts.

27 Danish Ballhead The illustration from a photo taken in Denmark is a good repreter Cabbage equals Danish Bathentation of the kind of seed we offer. For quality no other win-

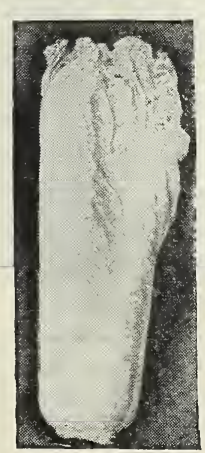
ways brings the highest market prices. One of the best keepers, coming out of the pit in March or April fresh and solid. The heads are not as large as

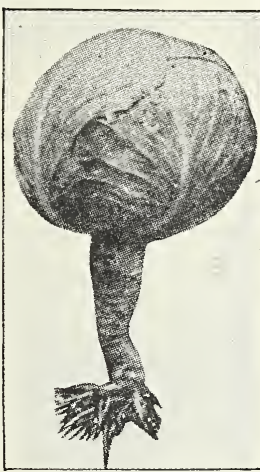

Danish Ballhead the American Drumhead varieties, but very much more solid. Pkt. 10c., 1/2 oz. pkg. 25c., 1/4 1b. \$1.25. 28 Drumhead Savoy Many consider the Savoys of the finest quality of all Cabbages. Savoy Cabbage, try it this year. You will be pleased with it. Pkt. 3 cts., $1 / 2$ ounce pkg. 10 cts. 29 Red Dutch Pickling The most popular of the red pickling varieties. Large round, very for slaw and pickling. There is always a market for red cabbage. Pkt. 5 cts., $1 / 4$ ounce pkg. 10 cts. 30 Pe-Tsai Chinese or Celery Cabbage. A new vegetable from China, that is attracting much the finest lettuce, or cooked like cabbage or spinach, it makes splendid greens. For main crop sow the seed last of August, aird transplant a fowt apart when large enough. Pkt. 5 cts., 1/4 oz. pkgs. 10 cts.

\section{Where the Best Cabbage Seed is Produced}

Cabbage Seed is largely grown on Long Island, in Washington near Puget Sound, in Holland and in Denmark. It is generally conceded that the most reliable seed comes from Denmark, and it is always the highest in price. We want our patrons to have the best, and therefore contract with reliable Danish growers for our entire requirements. 


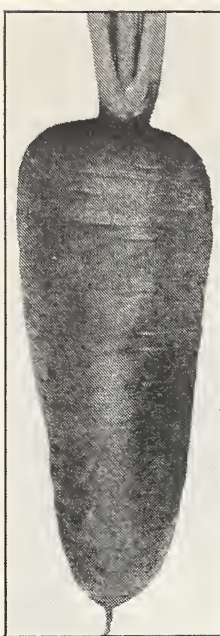

Danvers Carrot

\section{Carrots}

Each packet of Carrot seed will plant 30 to 40 feet of row.

31 Danvers Half-Iong. The most popular Carrot in cultivation. Originated at Danvers A favorite with market gardeners for bunching, making a fine appearance. In size, shape, color and sweetness, it is ideal. A first-class carrot for all soils. Pkt. 5 cts., ounce pkg. 10 cts., $1 / 41$ b. 30 cts.

32 Orbert or Guerande. Of very rapid growth. Short, thick roots, 2 Oxheart to 3 inches or more in diameter. Abrupt blunt point easily gathered. Finest quality for table use; also desirable for winter poultry food. Oxheart is often grown for stock feeding, yielding 15 to 20 tons per acre. Pkt. 3 cts., ounce pkg. 10 cts., $1 / 4$ lb. 30 cts.

33 Mastodon Giant White. Best and largest stock Carrot grown. O1 Nearly half its length grows above ground, making it easy to harvest. A wonderfully heavy yielder. Unsurpassed for feeding poultry and stock. Ounce Pkt. 10 cts., 1/4 1b. pkg. 25 cts., 1b. 80 cts.

We sold 140,000 Packets of Carrot Seed in 1920.

DELIVERY CHARGES PAID BY US on every item in this catalog. No parcel post, express or freight rates for you to figure out. Worth something to you, isn't it?

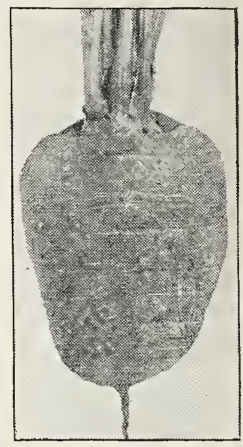

Oxheart

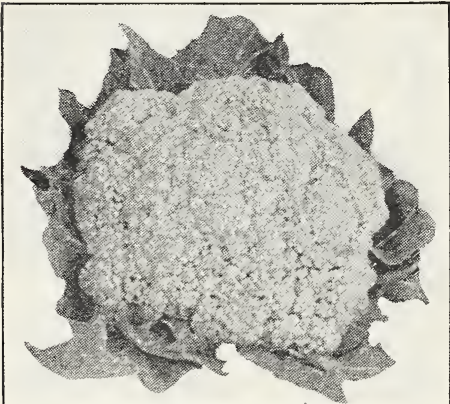

Cauliflower

34 Early Snowball We believe this to be the very best variety in existThen why should we list other varieties to do produce handle what we believe to be of the very best quality. Grown by one of the best known and most reputable growers in Denmark. We do not hesitate to recommend it, feeling sure that it will please the most critical grower. Pkt. 300 to 400 seeds, 10 cts., $1 / 8$ ounce pkg. 25 cts., ounce $\$ 1.50$.

Cauliflower requires an early start, and should therefore be sown early in boxes or hotbed and transplanted when large enough. Culture same as Cabbage. When the heads begin to form gather the outer leaves and tie together to protect from the hot sun. Cauliflower is one of the most delicious vegetables grown, and by planting our "Quality" Seed in rich, deep, moist soil the crop is almost as sure as cabbage. If you have not been successful heretofore, try again.

Snowball Cauliflower

\section{Celery}

Each packet of Celery seed should grow 400 to 600 plants.

35 Golden Self-Blanching The best of all early self-blanching varieties. It is of home and market than any other variety. Pkt. 8 cts., $1 / 4$ oz. pkg. 15 cts.

36 New Easy Blanching A new variety of great merit. The habit is dwarf and yellowish hue. It is very easily blanched, and might be termed a second-early variety, as it is

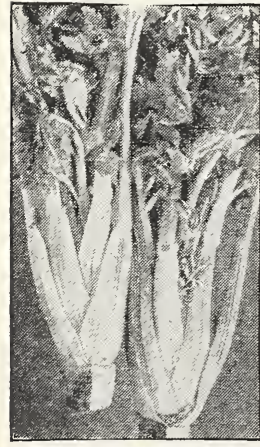

Golden Self-Blanching ready for use to follow Golden Self-Blanching. Due to the solidity of the stalks it is a first-rate keeper. and may therefore be grown for winter and spring use. The flavor is first class, while the stalks are pure white, heavy, and crisp. Pkt. 10 cts., $1 / 4$ ounce pkg. 20 cts.

37 Giant Pascal A standard fall and winter variety of vigA stous, compact growth. Stalks short, One of the best for winter use, excellent quality for home use, but too tender to stand shipping. Golden yellow heart, and fine nutty flavor. Pkt. 3 cts., $1 / 4$ oz. pkg. 10 cts.

38 Celeriac Turnip-rooted Celery. The large, solid, turnip-like Celeriac roots are highly esteemed for boiling or flavoring soups, etc. For winter and spring use, store same as turnips or beets Pkt. 3 cts., $1 / 4$ ounce pkg. 10 cts.

\section{Georgia Collards}

These belong to the cabbage family, and are largely grown in the South to use as boiling greens during the winter months. Also valuable for furnishing green forage for poultry, as it continues to grow all winter in the South. Pkt., about 1,000 seeds, 3 cts., $1 / 2$ ounce pkg. 10 cts.

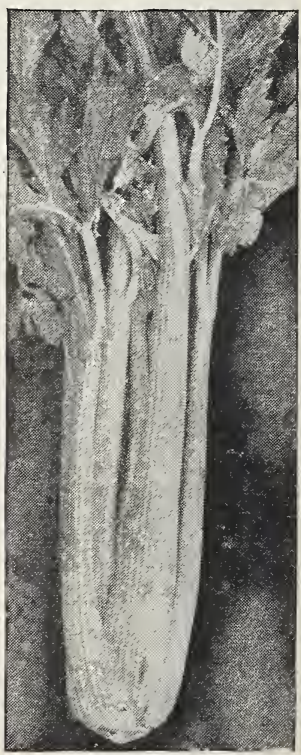

Easy-Blanching

We did not decide upon the phrase, "2uality Seeds," as a description of our seeds until we had been in this business for twelve years. By that time so many thousands of letters commenting on the quality had been received that we decided it was the only suitable phrase to use. And we are more zealous than ever in our efforts to maintain the quality, so that our seeds be not misbranded. 


\section{Sweet Corn}

Each quarter-pound of Sweet Corn will plant about 150 hills. 40 Extra Early White Cory The earliest and best of Corn. Ears 10 to 12 rowed, 7 to 8 inches long, fairly sweet, tender and white. Stalks about 4 feet high, usually producing two large handsome ears on each stalk. $1 / 4$ lb. pkg. 10 cts., 1 b. 30 cts.

11 Golden Bantam A very early Sweet Corn with goldenow grains. Generally considered existence. Probably more extensively grown than any other early variety. Ears 6 to 7 inches long. $1 / 4$ lb. pkg. 10 cts., 1 b. 35 cts.

42 De Lue's Golden Giant This valuable new Sweet Dr. DeLue of Boston, Mass. It has attracted so much attention, and was in such great demand last spring, that we were obliged to pay Dr. DeLue the unprecedented price of $\$ 1.25$ per pound for our stock seed. It is a cross between Golden. Bantam and Howling Mob, producing dwarf heavy stalks, usually carrying two large 12 to 14 rowed ears. Claimed to be fully equal to Golden Bantam in quality, and produces a

half more per acre. Give it a trial. Large $1 / 4 \mathbf{~ l b . ~ p k g . ~} 15$ cts., lb. 50 cts. 43 Black Mexican By many considered while young and tender, turning to bluish-black when ripe. Try it this year; you will be pleased. 1/4 1 b. pkg. 10 cts., 1 b. 35 cts.

44 New Golden Cream A golden yellow type of the popular Country pointed, placed irregularly on slender cob. The flavor is remarkably sweet and delicious. Give it a trial; you will be delighted. $1 / 4$ 1b. pkg. 10 cts., 1 b. 30 cts.

45 Country Gentleman or Shoe-Peg. A well-known, medium-early sired. Very productive. Market-gardeners who supply hotels and high-class restaurants depend on this for main crop. $1 / 41$. pkg. 10 cts., 1 b. 30 cts.

46 Stowell's Evergreen The standard main-crop variety, excelling all other most popular canning variety. Our stock was grown for us by one of the most careful growers. $1 / 4$ lb. pkg. 10 cts., 1 b. 30 cts.

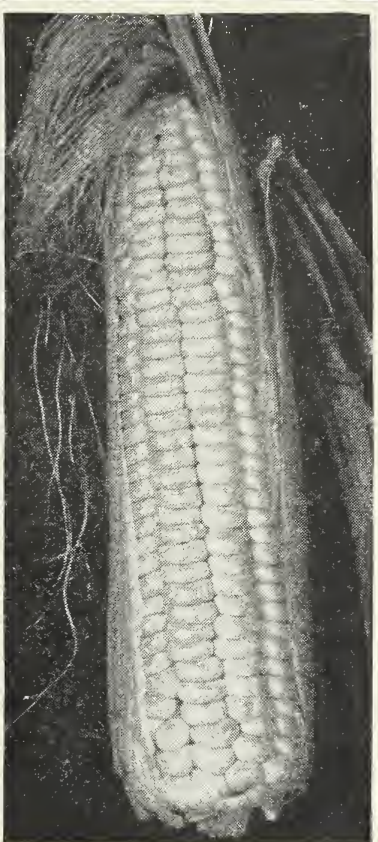

De Lue's Golden Giant

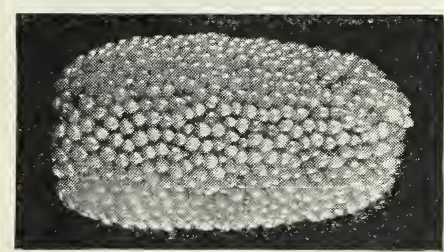

Japanese Hulless Pop Corn

\section{Pop Corn}

47 Improved White Rice Every boy likes to grow Pop Corn, and tory excelled. $1 / 4$ lb. pkg. 10 cts., 1 b. 35 cts.

48 Tapanese or Australian Hulless. A dwarf-growing corn, a heavy tese yielder of attractive ears, peculiar in form, being nearly as thick as long. The kernels are similar to the best strains of White Rice, only longer and slimmer and pearly white in color, but its crowning merit lies in its popping quality, fine flavor and absence of hull or shell. You will be delighted with this fine new variety. Ounce pkt. 5 cts., $1 / 4$ lb. pkg. 15 cts.

\section{Cucumbers}

Each packet of Cucumber seed will plant 12 to 15 hills.

49 Early Klondyke An extra-early strain of White Spine, remarkable for its shapely fruit and for the early northern markets, and equally desirable for the home-garden. Pkt. 5 cts., oz. pkg. 12 cts. 50 Davis Perfect This splendid Cucumber is a cross between White Spine and a large English Davis Priety. Fruit 7 to 9 inches long. Uniformly smooth and regular. The handsome dark green fruit always brings the highest market price. Flesh thick and solid with few seeds; of superb slicing quality. Pkt. 5 cts., ounce pkg. 15 cts.

51 Improved White Spine The best-known and universally satisfactory variety, more it in productiveness, and in color, form, and quality it is all that can be desired. Normal size 5 to 6 inches long and 2 inches in diameter. Pkt. 5 cts., ounce pkg. 12 cts., $1 / 416.35$ cts.

52 Extra Long Green A model in size, form, and color. Uniformly long and smooth, deep versal favorite for home use. Fruit 12 to 15 inches long, flesh solid and crisp with few seeds. Vines vigorous and productive. Pkt. 8 cts., $1 / 2$ ounce pkg. 10 cts., $1 / 41 \mathrm{lb} .50 \mathrm{cts}$.

53 Westerfield's Chicago Pickle This variety is preDavis Perfect others by many of the largest pickling establishments, as it meets the most exacting requirements of critical pickle makers. It is the right size, shape and color, and is considered to be one of the heaviest yielders and most dependable varieties grown. Pkt. 5 cts., ounce pkg. 12 cts., $1 / 4$ lb. 35 cts.

54 Jersey Pickle Very prolific and exceedingly chlar. Largely planted for pickles. The fruits are short, smooth, bright green and
of excellent quality. We recommend Jersey Pickle for the home garden. Pkt. 3 cts., ounce pkg. $10 \mathrm{cts}$.

We sold more than two hundred thousand packets of Cucumber seed in 1920.

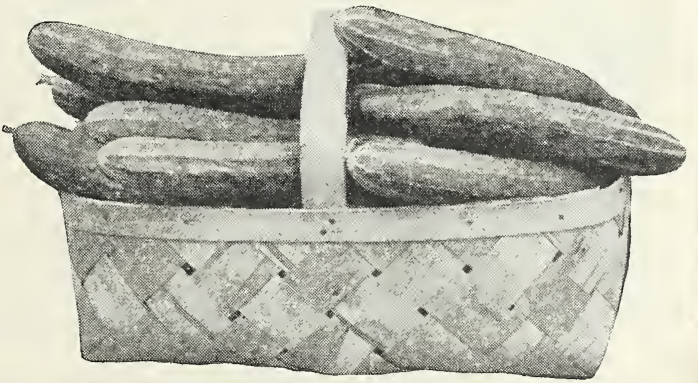

Extra Long Green Cucumber 


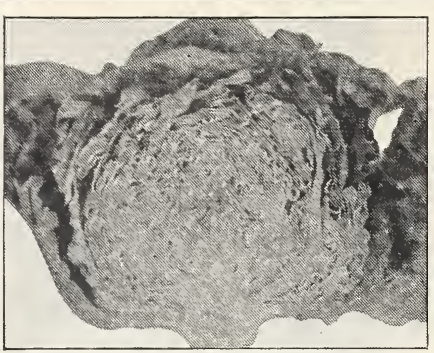

Improved Hanson

57 Improved Hanson In table qualson is perfection itself, being free from bitter taste. Forms immense, tender, crisp heads that remain long in good table condition. The outer leaves are large and broad, blistered and crumpled with frilled edges. Probably more largely grown than any other variety. Pkt. 3c, oz. pkg. 10c. 58 Big Boston A fine big, crisp, tender. Sure to please the most critical grower. Largely grown in the South to supply the Northern winter and early spring market, and equally good for growing in the home garden, both for early spring and autumn planting. Pkt. 5c, oz. pkg. 15c.

\section{Lettuce}

Each packet of Lettuce seed will contain about a quarter ounce.

55 Early Curled Simpson One of the most satisfactory varieties for heads of an attractive light yellowish green. The leaves are ruffled and curled, and alwaysvery tender. Resists heat and remains in edible condition a long time. The

Early Prize Head This popular old standard variety is still one of The leaves are very large, curled or crimped, bright-green tinged with brownish-red at the edges, and are exceedingly tender, crisp and sweet, forming large oose heads. Pkt. 5 cts., $1 / 2$ ounce pkg. 10 cts.

61 New York Cabbage or Wonderful. The best main summer crop hot grown, forming inmense heat-resisting heads, during the hot summer months. The outer color is dark green, but the heart blanches white, crisp and tender. Pkt. 8 cts., $1 / 2$ ou nce pkg. 15 cts.

62 Cos Romaine, or Celery. - An entirely distinct type of Lettuce that should 62 COS be more largely grown. By many considered superior in quality to all others. Forms oblong heads of large size, the main rib of each leaf curving inward, and blanching white and tender. Whecher grown in early spring, midsummer, or autumn, the leaves are always crisp and tender. Pkt. 5 cts., $1 / 2$ ounce pkg. 10 cts.

63 Mixed Tettuce An interesting packet, containing a mixture of all the or two high transplant a foot apart in rows, and watch the characteristics of the different varieties as they develop. Pkt. 3 cts., ounce pkg. 10 cts.

We sold more than 300,000 packets of Lettuce seed last year.

59 Burpee's Wayahead An extraLettuce producing medium-sized heads which are tightly folded, the inner leaves blanching to a rich, buttery yellow. Always crisp and tender. is remarkable how quickly this new lettuce has come into popular favor. We sold more than cts., ounce pkg. 15 cts.

60 California Cream Butter Also called Royal Summer Cabbage and German Butter. A reliable heading variety. The heads are a rich, creamy yellow inside and of a tender buttery flavor. Outer leaves green, spotted brown. Medium early and withstands the summer heat. Pkt. 5 cts., $1 / 2$ ounce pkg. 10 cts.

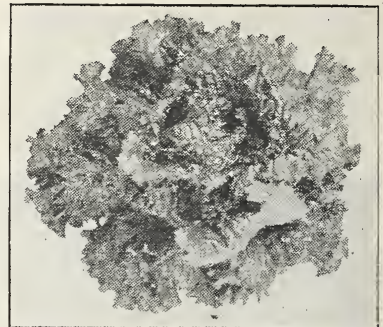

Early Curled Simpson

IT WOULD BE EASY to offer you more varieties of Lettuce than this, for there are hundreds of kinds. BUT, all of them are so nearly the same as one or another of these 8 that even an expert could not distinguish them. These are real leaders in each class. This policy is appreciated by our customers.

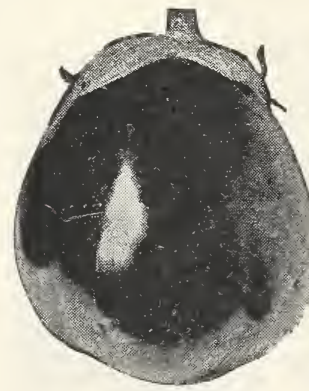

Egg Plant

\section{Egg Plant}

64 New York Spineless This variety is so far superior to all others that we believe doing our patrons a favor by refusing to list any be more extensively" grown. Detailed cultural instructions printed on each packet. Pkt. 5 cts., $1 / 8$ ounce pkg. 10 cts., 1 ounce $50 \mathrm{cts}$.

\section{Endive or Winter Lettuce}

65 Green Curled This is the best known and most desirable variety. Highly prized as ach. Seeds should be sown in July and transplanted in rows last of August. Blanching may be done by tying up the outer leaves or by covering with straw. Pkt. 3 cts., ounce pkg. 10 cts. 66 Kohlrabi ed "Turnip Rooted Cabbage". Forms large turnip-like bulbs on the stem above the ground. Should be used while young and tender, when they are sweet and nutritious. Culture same as for early cabbage. Very much sweeter than Turnips. Packet 3 cts., 1/4 ounce pkg. 10 cts.

67 T 10 or Borecole. Popular boiling-greens for fall, winter, and spring. Very popular in the South. Quite hardy and deserves more general cultivation in the North. Pkt. 3 cts., $1 / 2$ ounce pkg. 10c.

$68 \mathrm{~T}$ Broad London Flag. Belongs to the onion family, but does not 8 LeK form bulbs. The long thick neck of the plant is blanched in the fall and used same as young onions, having a sweet onion-like flavor. Popular in the South, but little known in the North. Pkt. 3c, oz. pkg. 20c. ${ }^{6}$ Mustard Chinese Curled. Very large, curled leaves, of very rapid growth. Much used in the South for salad and boiling-
greens, same as spiriach. Claimed to be very healthful. Pkt. (1000 seeds) 3 cts., ounce pkg. 10 cts.

Our Guarantee: You Must Be Satisfied or Your Money Back.

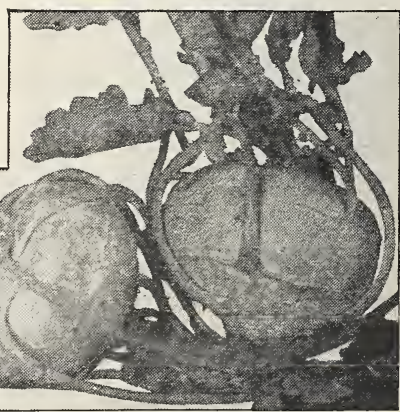

Kohlrabi 


\section{Muskmelon}

Each packet will plant 15 to 20 hills.

70 Extra Early Knight This we believe to be the earliest high quality Melon in existence today. It is ideal in size for dessert. Very sweet and melting. The fruit is of medium size, slightly oval; skin dark green, turning to golden yellow. Well covered with netting and distinctly ribbed. Flesh thick; color medium-green, blending to pink. Very popular in Manitoba and other Canadian Provinces, where other varieties will not mature. We do not hesitate to recommend this splendid melon for general home planting, as its extreme earliness, productiveness and excellent quality is sure to make it very popular. Pkt. 10 cts., ounce pkg. 20 cts., $1 / 4$ lb. 75 cts.

71 The Famous Honey Dew $\begin{gathered}\text { An entirely distinct } \\ \text { melon that created a }\end{gathered}$

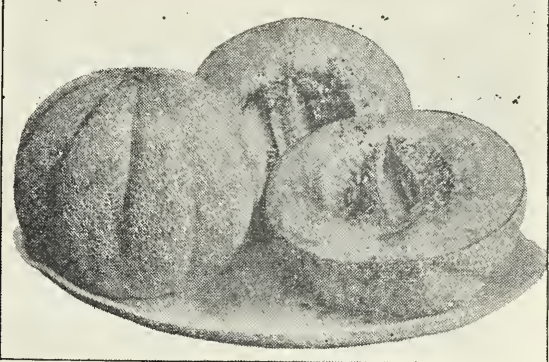

Extra Early Knight

sensation when first placed on the market. The fruit is quite large, 8 to $10 \mathrm{lbs}$, nearly round, perfectly smooth skin. Color

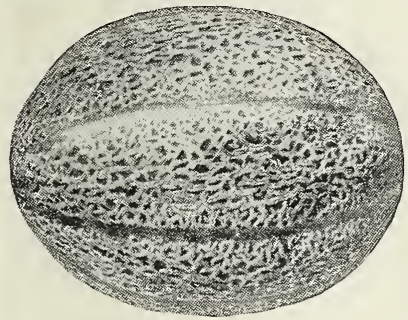

Rocky Ford Muskmelon nearly white turning to a light lemon yellow when fully ripe. When cut open revealing the crisp green flesh, it makes a beautiful contrast. In quality it is indescribably sweet with a distinctive delightful flavor. The name well describes it quality. Pkt. 10 cts., ounce pkg. 20 cts.

72 Banana A splendid home garden variety. The fruit grows 18 to 24 inches Banana in length. Flesh very thick, almost solid, rich salmon in color, and of superb quality when fully ripe. Pkt. 5 cts., ounce pkg. 15 cts.

73 Osage or Miller's Cream, sometimes called the Queen of Melons. One large, almost round, deeply ribbed. Color dark green melons to plant. Size medium the ribs. Flesh very thick, rich orange salmon, and of superb quality, sweet and melting. Pkt. 5 cts., ounce pkg. 15 cts.

74 Rocky Ford The best known variety and more largely grown than any Our seed is grown for us at Rocky Ford, Colo., which guarantees its quality flavor. cts., ounce pkg. 10 cts.

The United Banking \& Savings Co., of Cleveland, says: "For about ten years we have distributed free to our customers, seeds which we have purchased from The Templin-Crockett-Bradley Co. That we have continued this from year to year is indication that the quality has been entirely satisfactory."

(Signed) A. H. SEIBIG, President.

\section{${ }_{75}$ Vegetable Orange or Vine Peach}

Grows on vine similar to Muskmelon, requiring the same cultivation. The fruit is about the size and shape of a large peach, or orange. Color golden yellow. Recommended for sweet pickles, preserves or pies. A glass jar of these cut in halves and cooked in syrup presents an attractive and tempting appearance. Packet 5 cts.

\section{Watermelon}

Each Packet will plant 12 to 15 hills.

76 Cole's Extra Early Decidedly the finest variety for the home garden medium size and nearly round. Skin the North. Very hardy and productive, of granulated sparkling appearance, very sweet. Pkt. 5 cts., ounce pkg. 10 cts.

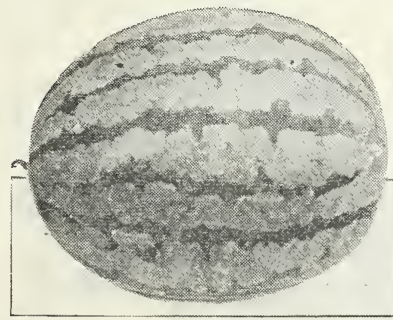

Cole's Early Watermelon

77 Golden Honey If you are prejudiced against golden fleshed watermelon, you will forget it after tasting Golden large, oblong, dark green. Try a packet. Pkt. 5 cts., ounce pkg. 10 cts. 78 Halbert's Honey Mne of the finest melons for the home garden, of superb luscious quality der and sweet. Pkt. 5 cts., ounce pkg. 10 cts., $1 / 4$ ib. 30 cts.

79 Tom Watson The most popular of all melons. Very largely grown for market. A long

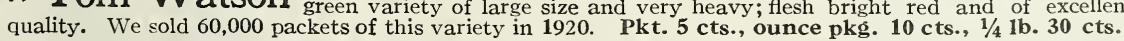
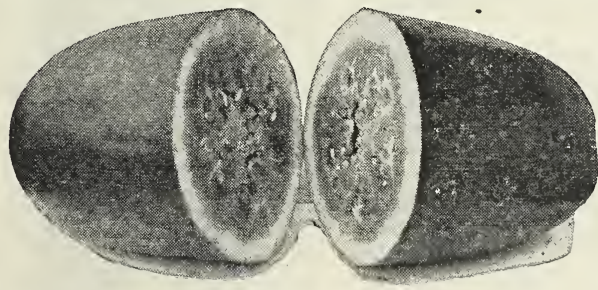

Tom Watson

80 Sweet Heart Large, heavy, oval mot fruit. Dark green, and sweet. Fruit vigorous and productive. Pkt. 3 cts., ounce pkg. 8 cts.

\section{Okra or Gumbo}

81 White Velvet Largely used in the arate dish and for soups. The tender seed-pods are cooked like asparagus. Should be more largely grown in the North. Pkt. (100 to 125 large seeds) 3 cts., ounce pkg. 10 cts.

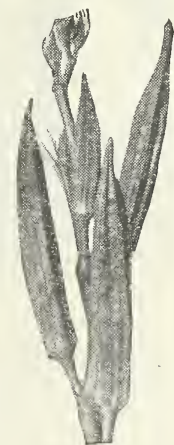

Okra

WE SOLD MORE THAN 200,000 PACKETS OF MELON SEED IN 1920, 


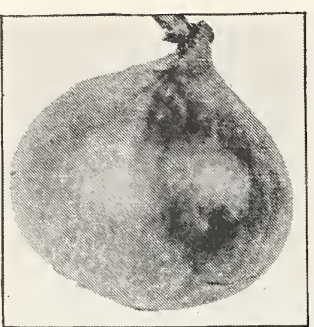

Prizetaker

\section{Onions}

Each packet of Onion seed will produce 400 to 500 Onions.

82 Ohio Yellow Globe Danvers A special selection of the popular Yellow grown for market in the great Onion growing sections of Ohio than all other varieties combined. The bulbs are uniformly globe-shaped, of good size, and bright straw-yellow in color. Also one of the best for growing sets. Pkt. 5 cts., ounce pkg. 15 cts., 1/4 lb. 50 cts.

83 Large Red Wethersfield This is a popular variety for winter markets, beexcellent keeper. With proper soil and cul-

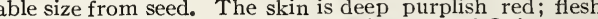

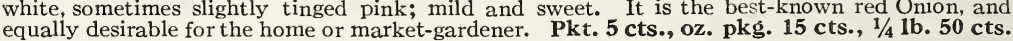

84 Mammoth Silver King This mammoth white variety is one of formly large size and fine shape, being flattened but thick. The skin is of a beautiful silvery white, flesh snowy and tender, of a mild, sweet flavor. Its large size and handsome appearance recommend it for exhibition at fairs, for the fancy market, as well as for the home table. Pkt. 8 cts., ounce pkg. 20 cts.

85 Prizetaker A splendid large-growing variety to grow for fall markets or from seed to weigh home use. With favorable conditions they may be grown Handsome, straw-yellow skin, resembeen grown to the acre. Pkt. 5 cts., ounce pkg. 20 cts., $1 / 4$ lb. 65 cts.

86 Southport White Globe The most attractive white Onion grown, prices. Perfect globe-shape, and clear, transparent skin; flesh crisp, fine-grained, and mild in flavor. Pkt. 5 cts., ounce pkg. 20 cts., 1/4 1b. 70 cts.

87 Southport Red Globe A beautiful, large, globe-shaped red Onion. fall and winter markets. The seed we offer was specially grown for us from perfect, globe-shaped stock. Pkt. 3 cts., ounce pkg. 15 cts., $1 / 41$ 1b. 60 cts.

\section{Pickling Onion}

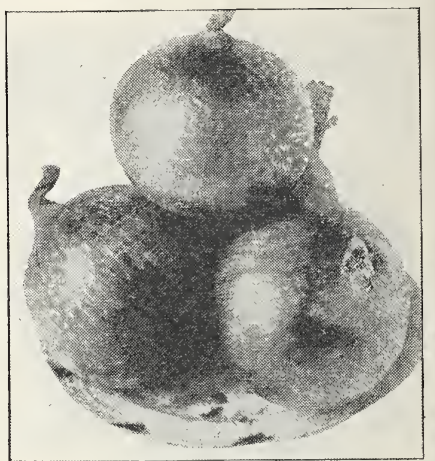

Ohio Yellow Globe Danvers 88 Extra Early Silver Bell The earliest Onion in cultivation, being a selected strain of the Italian Berletta The skin is pure transparent, waxy, silver-white; very mild flavor. Pkt. 8 cts., ounce pkg. 25 cts.

Our Onion Seed is all grown for us under contract, by the most careful growers, and we believe it to be of the very highest quality. The fact that we sold more than 225,000 packets in 1920 is pretty good evidence that the quality is right. Special price for seed to plant for Sets, Red or Yellow, Ib. \$1.25.

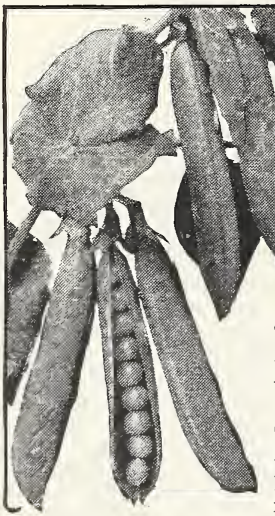

Alaska Peas

\section{Garden Peas}

Each packet of Peas will contain a quarter-pound.

89 Extra Early Alaska or Earliest of All. The hardiest of the smooth bluish green very any other variety. Also very largel grown to supply canning factories. For first planting always plant Alaska. Height 2 feet. $1 / 4$ lb. pkt. 10 cts., 1 lb. 35 cts.

90 First-in-Market Extra-early, smooth, white-seeded. Wonderfully profilled pods $21 / 2$ to 3 inches long. Largely grown for early markets. Also known under the name of "First and Best". $1 / 4$ lb. pkt. 10 cts., 1 b. 35 cts.

1 Nott's Excelsior A very fine, highly bred variety of sturdy, compact, dwarf growth. to 20 inches high. Large pods chock-full of large luscious peas of unusually sweet flavor. One of the earliest of the large wrinkled varieties, and one that is sure to please you. Large $1 / 4 \mathrm{lb}$. packet 12 cts., $1 \mathrm{~b}$. $40 \mathrm{cts}$.

92 Thomas Laxton The vine grows about $2 \frac{1}{2}$ feet high. Very vigorous and produclarge, fine colored and unsurpassed in splendid quality. Will sat-
late isfy the most critical. Large $1 / 4$ lb. pkt. 12 cts., lb. 40 cts.

93 Peter Pan One of the very finest of the large podded, ton, but much more dwarf. Height only 15 to 18 inches, requiring no brush. Vines and foliage very stout, heavy, and dark green. Pods 4 inches long, very broad, with 7 or 8 very large, dark green peas of superb quality. We do not hesitate to recommend this as one of the very best. Large $1 / 41$ lb. pkt. 15 cts., lb. 45 cts.

94 Alderman Height $4 \frac{1}{2} \mathrm{ft}$. Of the well known Telephone type, but of a darker Alderm color. Very robust and productive. Peas of large size and un surpassed in quality. Best of the large main-crop varieties. 1/4 1b. pkt. 12 cts., lb. 40 cts,

\section{Edible Podded Peas}

95 Mammoth Melting Sugar Height 5 feet. Well deserves its name the same as wax beans. Pods are stringless and Should be cooked and eaten pods and all, Should be in every home garden. Large $1 / 4 \mathrm{lb}$. pkt. $12 \mathrm{cts}$., lb. 40 cts.

96 Dwarf Gray Sugar Height 18 inches. Similar to Melting Sugar, but of pods about 3 inches in length. $1 / 4 \mathbf{~ l b}$. pkt. 10 cts., lb. 35 cts

Our Guarantee:-You Must Be Satisfied or Your Money Refunded.

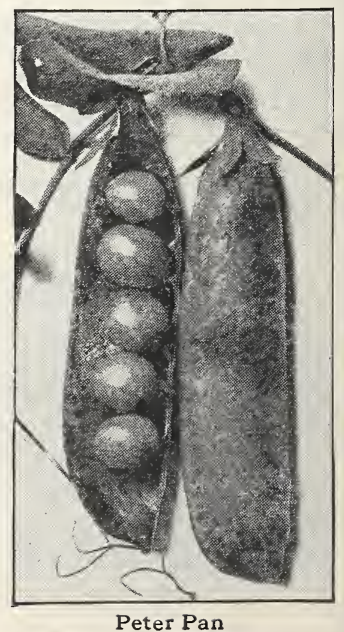




\section{Parsnip}

97 Large Sugar Improved Hollow Crown or Guernsey low Crown Roots ductive. Large white roots, tender and sweet. Generally considered the best. Then why should we confuse the buyer by listing 3 or 4 other varieties? Pkt. 5 cts., Large ounce pkg. $10 \mathrm{cts}$.

\section{Parsley}

98 Champion Moss Curled Very useful for flavoring garnishing. Use the tender green leaves. The leaves may also be dried, pulverized to a powder, and kept in bottles for winter use. Pkt. 3 cts., $1 / 2$ ounce pkg. 10 cts.

99 Hamburg Turnip-Rooted The roots which resemble a small parsnip, are used instead of the leaves, and Turnips. Pkt. 3 cts

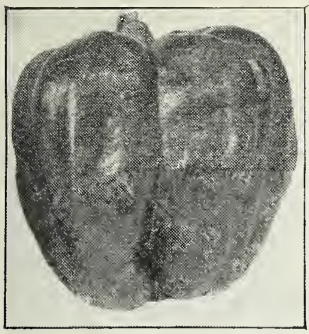

Royal King Pepper

\section{Pumpkins}

Each packet will plant 10 to 15 hills.

102 Small Sugar Pie Is so well known as the best pie pumpkin it requires little fine grained flesh, and such a sweet, sugary, delicious flavor they all call for "more." pkt. 5 cts., ounce pkg. $15 \mathrm{cts}$.

103 Tennessee Sweet Potato Excellent sort which resembles a Sweet Potato The color is a creamy-white, sometimes striped in flavor. It is pear-shaped and slightly ribbed. colored, fine grained and very dry and of superior flavor. Pkt. 5 cts., ounce pkg. 15 cts. 104 Tumbo or King of Mammoths. Fruit grows to enormous size -often 150 to 200 $104 \mathrm{Jumbo}$ pounds. Orange skin and yellow flesh of good quality for pies. Plant singly in rich soil, and beat your neighbors at the county fair next fall. Pkt. 8 cts., ounce pkg. 20 cts.

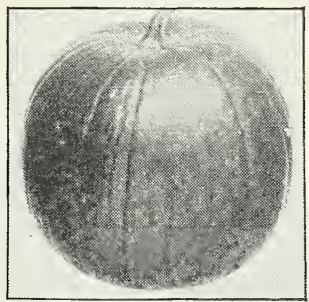

Sugar Pie

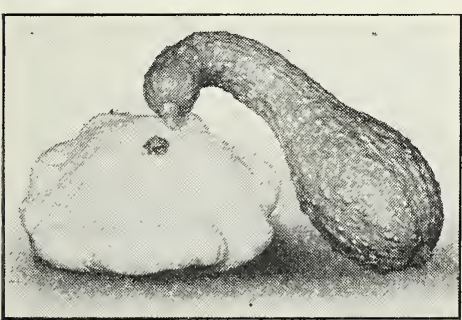

Custard and Crookneck Squashes

\section{Squashes}

Each packet will plant 10 to 15 hills.

105 Golden Custard Yellow Bush Scallop or Patty-Pan. The earliest tender. Pkt. 3 cts., ounce pkg. 12 cts.

106 Early Summer Crookneck The best known early Bush golden yellow. Very productive and fine quality. A general favorite. Pkt. 5 cts., ounce pkg. 15 cts.

107 Prolific Orange Marrow size and shape similar to Huborange yellow. Thick yellow flesh that is rich and sweet. Excellent for pies. Popular fall and early winter variety. Pkt. 3 cts.,

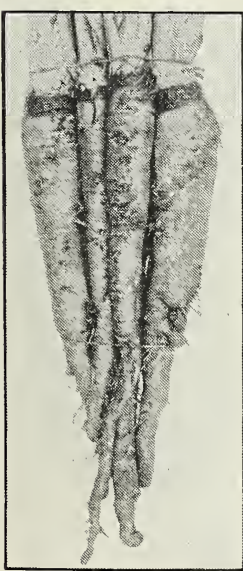

Salsify ounce pkg. $10 \mathrm{cts}$. 108 Delicious A most desirable new winter the originator of squash introduced by Gregory well known Hubbard. About dark orange in color. Very dry, sweet, and of rich flavor. A squash of exceptional merit for table use. Usual weight 5 to $10 \mathrm{lbs}$. It is fine during the fall, but its best quality is not attained until winter. Pkt. 5 cts., ounce pkg. 20 cts., 1/4 1b. 50 cts.

109 Genuine Hubbard The well-known so largely grown throughout the country. Large size, dark green in color, hard shell, thick deep orange flesh of the highest quality. An excellent winter keeper, none better. Pkt. 5 cts., ounce pkg. 20 cts., $1 / 4$ lb. 45 cts.

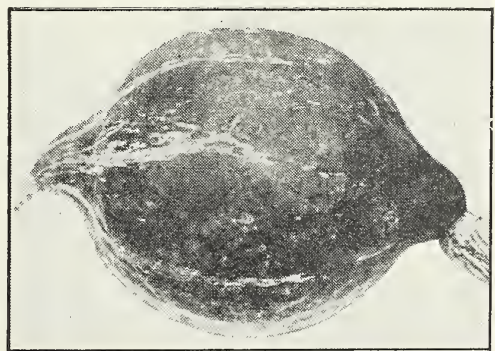

Hubbard Squash 110 Mammoth Chili A mammoth exhibition Squash. Has been grown to weigh more quality. Pkt. (15 to 20 seeds) 5 cts., ounce pkg. 20 cts.

\section{${ }^{11}$ Salsify or Vegetable Oyster}

Why don't you grow Salsify? It is one of the most delicious and nutritious of vegetables. In soup it has a delicious oyster flavor. Also fine if fried in butter, or boiled and made into fritters. It is perfectly hardy and should remain in the garden for spring use. Pkt. 5 cts., ounce pkg. 15 cts. 


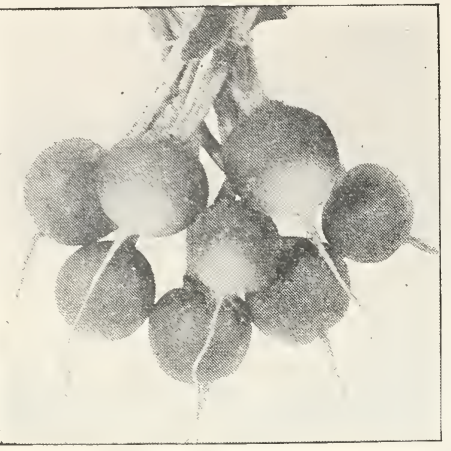

Round Radishes

\section{Radishes}

Each packet will contain $1 / 4$ ounce, 500 or more seeds.

112 Earliest Scarlet Globe This is one of the most popular of the eties. It is of rapid growth, brilliant scarlet in color. Has small tops, and is probably more largely grown for home and market than any other variety. We have a very fine strain. Pkt. 5 cts., ounce pkg. $10 \mathrm{cts} ., 1 / 4$ b. $35 \mathrm{cts}$.

113 White Tip Scarlet Gem or Sparkler. A very early and turnip shaped class: Bright scarlet with a distinct scarlet variety of the globe or home and market. Pkt. 3 cts., ounce pko. 10 cts., $1 / 4$ lb. 30 cts.

114 Crimson Giant Also called Giant Butter Radish. This is a new in-shaped type, and equally suitabl radish, double the size of any of the early turIt is a rapid growing sort, developing roots of a beautiful deep crimson color, which vary in shape from round to almost oval, and often measure 5 inches in circumference. The flesh is the purest white, mild in flavor, firm and crisp, remaining in edible condition longer than other early sorts. We recommend this radish very highly. Pkt. 5 cts., ounce pks. 12 cts., 1/4 1 b. 40 cts.

There are two kinds of Radish Seed. One will produce good, crisp roots; the other will run to tops. Our seed has been carefully selected for its root forming quality.

115 Philadelphia White Box An early variety, very popular with market inches in diameter, with pure paper-white skin; crisp mild flesh. Has a small top and matures quickly. Pkt. 3 cts., ounce pkg. 10 cts., $1 / 4$ ib. 25 cts.

116 French Breakfast A most beautiful radish of true olive shape. Color bright Breakfast is an exceedingly early variety and must be eaten as soon as fully developed, to have it firm and crisp. Very tender and mild. Pkt. 3 cts., ounce pkg. $10 \mathrm{cts}$., 1/4 1b. 35 cts.

117 Earliest Long Scarlet The finest strain of the most popular Radish.

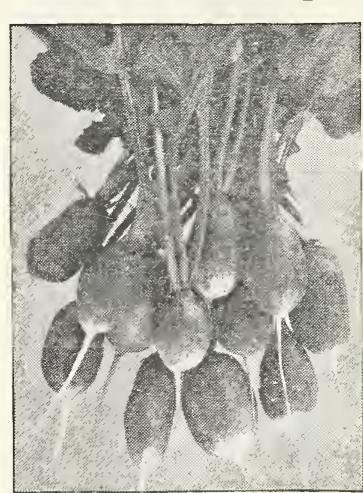

French Breakfast attractive. brittle and of choicest quality. Length 5 to 6 inches. Best for mid-summer use. Pkt. 5 cts., ounce pkg. 10 cts., 1/4 1b. $25 \mathrm{c}$.

118 Long White Icicle The finest White Radslender root which remains tender and crisp until grown. Matures early, has small top which permits close planting. Considered by many to be the finest radish. Plant every 10 days for succession. Pkt. 5 cts., ounce pkg. 10 cts., $1 / 41$ lb. 30 cts.

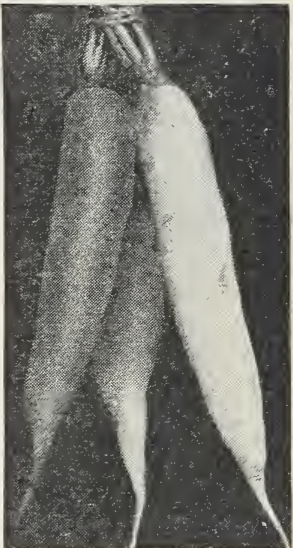

No. 117 No. 119

No. 118

119 Chartier or Shepherd. Well known, .popular variety, entirely distinct. Long regular tapering roots, a clear rose color shading into pure waxywhite at the tip. Crisp and tender. Pkt. 3 cts., ounce pkg. 10 cts.

120 All Seasons Radish Mixture Each packet contains a mixture of An interesting packet for small gardens. If you all the above described varieties. this is the one to order. Pkt. 3 cts., ounce pkg. 10 cts.

121 Winter Radishes Winter Radishes should be planted in August. If 121 inter Radishes planted in early spring, they will run to seed without forming root. Each packet will contain a mixture of several varieties, including China Rose, Celestial or Mammoth White China, Round and Long, Black Spanish, etc. Store the same as turnips for Winter use. Pkt. 3 cts., ounce pkg. 10 cts.

122 Tapanese Radishes An interesting packet, containing a mixture of the following: Bottle Radish, Long 122 Japanese Radishes String Radish, Mjyashige, Nerima, Mammoth Shogoin, and Giant Sakurijima, that grows to weigh $30 \mathrm{lbs}$. Try a packet for Fair Exhibition. Pkt. (150 seeds) 5 cts.

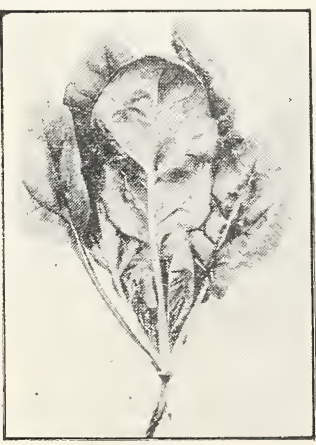

Spinach

\section{Spinach}

123 Bloomesdale Savoy A most valuable variety. is wrinkled in the same way as that of the Savoy Cabbage, hence the name. It produces nearly twice the bulk of crop as the ordinary sort, is fully as hardy and in all other respects equal. Pkt. 3 cts., ounce pkg. 10 cts., $1 / 4$ 1b. 25 cts.

\section{New Zealand Spinach}

124 Tetragonia This is an entirely distinct species, forming low spreading plants 4 to 5 feet across, producing an abundance of thick, juicy, tender branches to be served same as Spinach. Of fine quality, producing its tender branches throughout the hottest Summer weather. Well worthy a trial. Pkt. 5 cts., ounce pkg. 15 cts.

\section{Swiss Chard}

125 Spinach Beet No other vegetabl will produce more nutritious food from a small iful strongly recommend it. Pkt. 5 cts., Large ounce pkg. 10 cts.

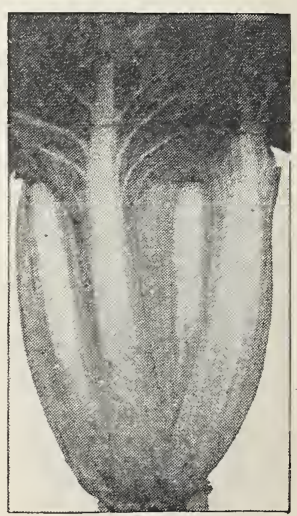

Swiss Chard 


\section{Tomatoes}

Each packet will contain 200 to 300 seeds.

126 Spark's Earliana There are a number of Tomatoes that are found any earlier than Spark's. The fruit is of medium size, always smooth, bright scarlet and of excellent quality. Pkt. 5 cts., $1 / 2$ ounce pkg. 15 cts.

127 The Landreth In carefully comparing the relative merits of the 127 The Landreth many varieties of Tomatoes, we have selected the compelled to grow but one variety of Tomato it would be the Landreth. It begins to ripen extra early, 2 or 3 days after Earliana. The fruit is medium large, not quite as large as The Stone, but just the size the housewife likes. Color brilliant blood red. Always smooth, solid and meaty. Vines short-stemmed, sturdy, and very productive. While it is extra early its productiveness and long fruiting period qualify it as a splendid main crop variety. Pkt. 10 cts., 1/2 ounce pkg. $40 \mathrm{cts}$., ounce pkg. 75 cts.

128 New John Baer Claimed to be extra-early. iant red, solid excellent quality, Medium large, beautiful brilWe believe it worthy a trial by and enormously productive. cts., $1 / 2$ ounce pkg. 25 cts.

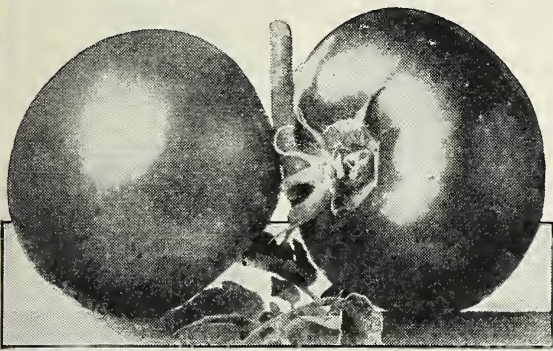

130 Red Rock An extraordinarily solid, smooth, bright red To129 Early Acme The best known of all the Purple ple will plant no other. Medium varieties. Many peoy solid and smooth. Very productive; quality very fine. Pkt. 5 cts., 1/2 oz. pkg. 15 cts.

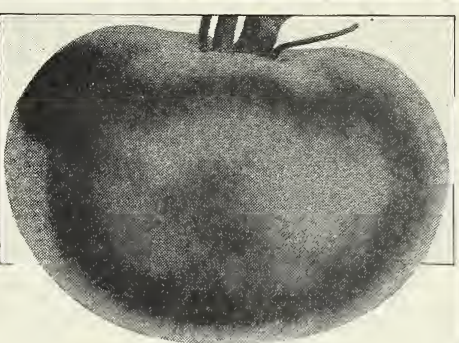

The Landreth quality. Very popular with canners and truckers pkt. 3 cts ounce pkg. 15 cts.

131 New Stone The standard main-crop variety. The fruit is of best table quality. dependable for main crop. Pkt. 3 cts., $1 / 2$ oz, pkg. 15 cts.

132 Ponderosa This is not only the largest but also the heaviest Comato grown. Color glowing purple-crimson. Considered by many the best table variety in existence, especially by those who prefer a tomato quite free from acid. Being very solid, with few seeds, it is very desirable for slicing. Pkt. 10c., 1/2 oz. pkg. 25c. 133 Small Preserving Tomatoes An interesting packture of small preserving varieties, including Red and Yellow C merryPeach, Plum, Pear and Currant. Also yellow and purple husk Tomatoes. These varieties are not only desirable for preserves, but dried in New Stone and Acme Tomatoes sun, packed down with sugar make splendid substitute for figs. Pkt. 5c.

\section{Turnips}

Each packet will contain $1 / 4$ ounce, about 2,500 seeds.

134 Extra Early Milan Earliest Turnip in cultivation; a week sooner with bright purple top and few leaves. Flesh white and choice. Adapted to Spring or Fall. A good keeper. Pkt. 5 cts., ounce pkg. 15 cts., 1/4 1b. 40 cts.

135 Purple Top Strap-Leaf The standard for this part of the country. fat ounce pkg. 10 cts., $1 / 4$ lb. 25 cts.

136 Purple Top White Globe This is one of the handsomestand most

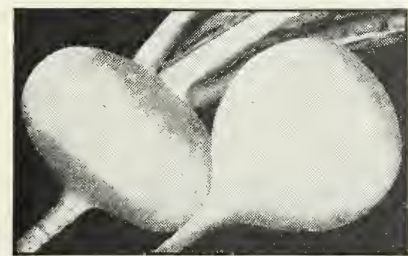

No. 135 Turnips No. 137

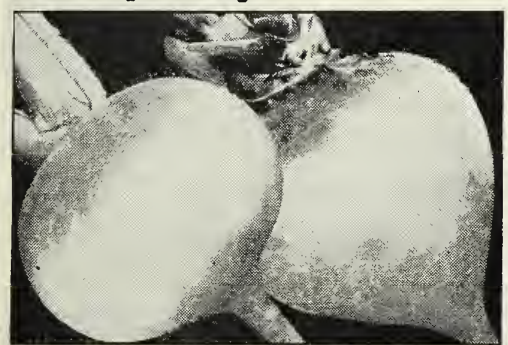

Turnip No. 136 and Rutabaga No. 139 desirable varieties grown. Very similar to the above variety, except in
shape, being a perfect globe-shape. Fot home and market. Pkt. 3 cts., ounce pkg. 10 cts., $1 / 4$ lb. 25 cts.

137 White Egg Forms a beautiful, egg-shaped root with thin white 3 cts., ounce pkg. 10 cts., $1 / 4$ 1b. 25 cts.

138 Golden Ball or Orange Jelly. One of the most delicate and Medium in size. Uniformlyeetest of yellow-fleshed Turnips yet introduced. table variety. Pkt. 3 cts., ounce pkg. 10 cts., 1/4 lb. 25 cts.

139 Rutabaga American Swede. Produces uniformly large, globebelow. Flesh very solid, rich yellow, fine-grained, and very sweet. Largely grown for market and stock. Always solid, and will keep until late spring. Pkt. 3 cts., ounce pkg. 10 cts., $1 / 4$ lb. 25 cts.

\section{Miscellaneous}

140 Lawn Grass Success depends on a well balproper preparation of the soil. The time to sow the seed is just as early in spring as the soil can be properly prepared. The seed we offer is absolutely pure, clean seed and should not be compared with the chaffy stuff so often sold. Our mixture comprises mostly Kentucky Blue Grass, Canada Blue Grass, Red Top and White Clover, a combination that insures a fine velvety lawn. Large package for mending bare spots, $10 \mathrm{cts}$., 1 pound (will sow 500 square feet) $45 \mathrm{cts}$., $5 \mathrm{lbs}$. $\$ 2.00$.

141 Pure White Clover It is often advisable to portion of White Clover, especially in poor clay soil. Also for renovating old lawns the Clover will often take hold where other grasses fail. $1 / 4$ lb. 25 cts., 1 b. 85 cts.
142 Extra Early Spanish Peanuts $\begin{gathered}\text { It is } \\ \text { not }\end{gathered}$ generally known that Peanuts can be successfully grown in the North. By planting the extra early Spanish, they mature a nice crop if planted on light, sandy soil in full sunshine. The nuts are not quite so large as the ones usually sold, but are very solid and sweet. Just what the boys will want to plant. Plant just like beans, after the soil is quite warm, usually last of May. Large pkt. 5 cts.

143 Mammoth Russian Sunflower ${ }_{\text {best }}^{\text {The }}$ egg-producing food known for poultry. Every farmer should plant some of the seed in any out-of-the-way place at any time in May or June. Single heads will often measure 12 to 15 inches across and contain an immense quantity of seed. Hang the heads in the poultry-house, where the hens can reach them, and they willdo the rest. Oz. pkg. 5c, $1 / 41 \mathbf{l b} .10 \mathrm{c}, 1 \mathrm{~b} .30 \mathrm{c}$. 


\section{QUALITY FLOWER SEEDS}

In selecting the following list of Flower Seed, we have been very careful to include only varieties of comparatively easy culture, that with reasonable care will be certain to give general satisfaction. In the "Thousand and One" kinds of flower seeds we might offer, there are many varieties that require special care, which are almost certain to disappoint the purchaser. All such varieties have been omitted.

EVERY PACKET OF FLOWER SEED CARRIES OUR REFUND GUARANTEE.

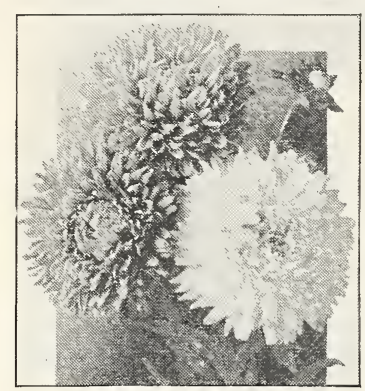

Queen of the Market

\section{Quality Aster Seeds}

Our Aster Seed has gained a Nation-wide reputation for quality. Almost 300,000 packets were sold in 1920 and not a single complaint received. Our seeds are grown under contract by the most careful and trustworthy growers in America. It required almost 400 pounds to supply the demand. No better Aster Seed is obtainable, no matter what prices are asked for them.

Each Packet will contain 200 to 250 seeds.

151 Queen of the Market The hest of the ties, fully two weeks ahead of all others. Flowers quite large and perfectly double. Mixed colors. Pkt. 5 cts., $1 / 8$ oz. pkg. 15 cts.

152 American Branching Very popular. 2 to $21 / 2$ feet in height. Large, perfectly double flowers on long stems.

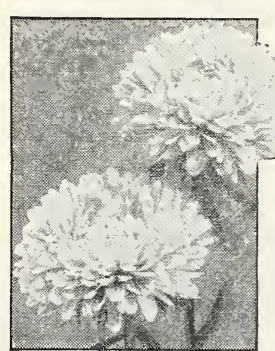

American Beauty

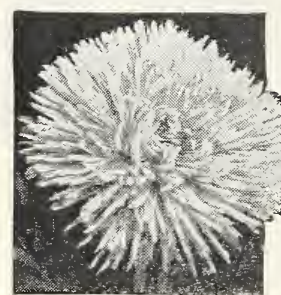

New King All colors mixed. Pkt. 5 cts., $1 / 8$ ounce pkg. 15 cts.

153 American Beauty One of the most beautiful Asters of Dery vigorous perfectly double flowers on long stems. The color carmine rose color. Pkt. 10 154 Giant Branching Comet rhape differs from allothers, $_{\text {resemb the Ja pa nese }}^{\text {Shang }}$ Chrysanthemum. The flowers are from 3 to $4 \frac{1 / 2}{2}$ inches in diameter, perfectly double, on long stems. One of the very best. Pkt. 10 cts., 1/8 ounce pkg. 25 cts.

155 New Giant Crego Strong, well branched plants, two long stems, petals irregularly curled and twisted. Very fine. Pkt. 10 cts., $1 / 8$ ounce pkg. 20 cts.

156 New King Aster A distinct new type. Very large, double needle-like petals. Very attractive, all colors. Pkt. 10 cts., $1 / 8$ ounce pkg. 25 cts.

157 Ostrich Plume A fine ty pe of Giant Comet, having very ing a plume-like effect. Flowers very large, on long stems; fine for cut flowers. All colors mixed. Pkt. 10 cts., $1 / 8$ ounce pkg. 20 cts. $<$ 158 One packet each of above 7 varieties for 45 cts.

159 Extra Quality Mixed A mixture of all theabove and 10 cts., $1 / 8$ ounce pkg. 20 cts., ounce pkg. $\$ 1.25$.

Asters in Separate Colors desirable varieties, having long stems. Suitable for Cut Flowers. 160 Pure White Varieties, mixed. Pkt. 250 seeds, 10 cts.

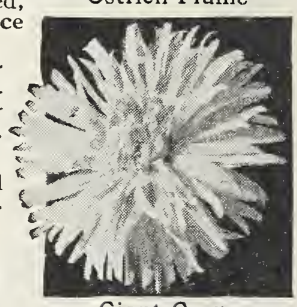

Giant Crego 161 Delicate Flesh Pink Varieties. Pkt. 250 seeds, 10 cts. 162 Light Blue and Lavender, mixed. Pkt. 250 seeds, 10 cts.

\section{Sweet Alyssum Little Gem.} compact habit. Blooms from early spring to frost. Excellent for bordering bedsorwalks; also desirable for hanging-baskets or vases. Flowers pure white, fragrant, completely covering the plants. Pkt. (600 to 800 seeds) 3 cts., $1 / 4 \mathrm{Oz} .10 \mathrm{c}$.

164 Amaranthus Love-Lies-Bleeding. als; ornamental foliage; long, drooping panicles of flowers. Of very easy culture. pkt. (500 or

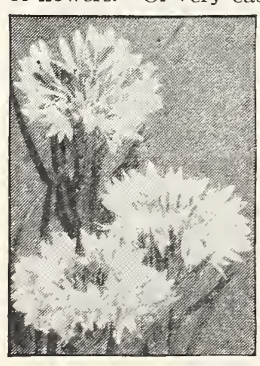

Bachelor's Button pkg. $20 \mathrm{cts}$.

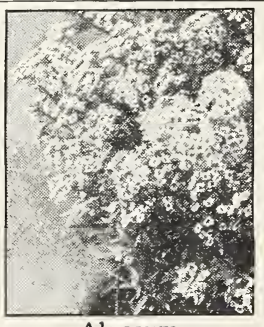

Alyssum

\section{Bachelor's Button}

Ragged Robin, Cornflower, or Blue Bottle. One of the most popular and desirable of old-fashioned garden annuals. Bachelor's Button and Baby's Breath make a most beautiful bouquet. Quite hardy, coming up each spring. Pkt. (about 200 seeds) 3 cts.

\section{Double Balsam}

A most beautiful annual, commonly called "Ladies Slipper" and "TouchMe-Not", forming neat symmetrical tree-like plant, and a prof usion of double and semi-double wax-like flowers, in the most brilliant colors. A fine mixture of Camellia and Rose flowered varieties. Pkt. 5 cts., $1 / 4$ ounce

165 Baby's Breath Gypsophila. Very als, 12 to 15 inches high. The flowers are pure white, very small, star-like, and produced in 166 Blanket Flower Gaillardia. Very Blank annuals of Flowers on long stems in orange, brown, bronze, maroon, and crimson. Mixed varieties, including the Lorenziana double type. Pkt. (about 200 eeds) 3 cts.

Giant Comet

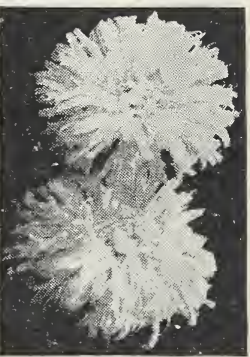

Ostrich Plume 


\section{\begin{tabular}{ll}
\hline$x y$ & Carnations
\end{tabular}}

169 Double Marguerite These lovely, fragrant Carnations produce garden early in the spring. The plants begin to bloom in about four months. When well started, the young plants should be transplanted to stand twelve inches apart. They are quite hardy, flowering the first season until late in the fall and can be potted for winter blooming. Mixed colors. Pkt. (250 seeds) 10 cts.

\section{Calendula}

170 Scotch Marigold Calendulas are becomorange and yellow flowers are very attractive. Of very easy culture, blooming continually from June to October. Pkt. (100 seeds) 3 cts.

\section{California Poppy}

171 Eschscholtzia Extremely handsome, low and quick growing annuals, with finely cut bluish foliage and cheerful, bright colored, poppy-like blossoms. Nothing can excel it in brightness. Bloom continually rom June to October. Colors orange, yellow, crimson and maroon. This is the State flower of Cali-

Marguerite Carnation fornia. Everybody should grow it. Pkt. (600 to 800 seeds) $3 \mathrm{cts}$. $1 / 4$ ounce pkg. $15 \mathrm{cts}$.

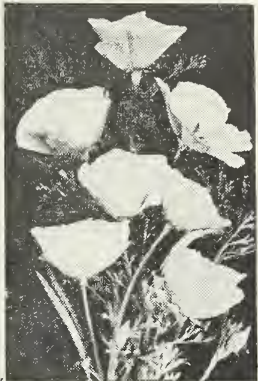

California Prsppy

172 Candytuft One of our most useful and popular annuals. Completely covered with clusters of flowers that are pared. Many colors, mixed, including the Giant Hyacinth-flowered type. Pkt. (about 500 seeds) 3 cts.

\section{Chinese Wool Flower}

173 Celosia Childsii a distinct form sia, each stem bearing beautiful ba!l-shaped flower heads of brilliant purplish crimson. The curled petals give the appearance of wool. Very attractive. Pkt. (250 seeds) 10 cts.

\section{Calliopsis}

174 Coreopsis One of the leading plants making a very showy border plant, producing flowers in nearly every shade of yellow, orange, crimson, red and brown. Pkt. (500 seeds)

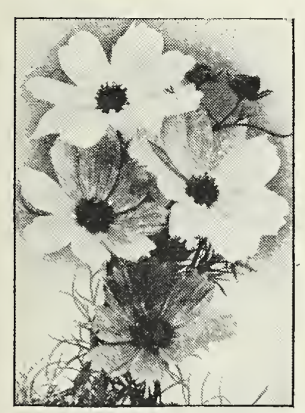

Cosmos

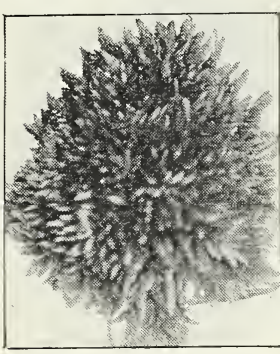

Chinese Wool Flower

\section{Ostrich Plume Celosia} 175 Magnifica A very beautiful type of feet high, with magnificent feathery like plumes in brilliant colors. Always attracts attention. Very easy culture. Pkt。(300 to 400 sás.) 5 c.

\section{Cockscomb}

176 Celosia Cristata Very showy extra large, velvety flower-heads or combs. Of very easy culture. Cut when partially open, and hang in a dark closet to dry, for winter decorations. Dwarf, large-flowering type. Pkt. (300 to 400 seeds) $3 \mathrm{cts}$.

\section{China and Japan Pinks}

177 Dianthus One of the most popular and satisfactory annuals grown. They are of are deeply fringed. They are quite hardy and with protection will winter over and bloom very freely in early spring. Our mixture contains many varieties of Chinese and Japanese sorts. We sold more than 200,000 packets in 1920 . Pkt. (300 to 400 seeds) $5 \mathrm{c}, 1 / 8 \mathrm{oz}$. pkg. $15 \mathrm{c}$.

\section{Cosmos}

178 Giant Flowering Very desirable, tall, graceful annuals, 5 to 6 feet high, with Wering large, single, showy flowers from August to October. To provide a succession of flowers, we include both the new early giant-flowering and late giant-flowering varieties in each packet. They should producean abundance of flowers from August until killed by frost. Colors, white, pink and crimson. Pkt. (150 seeds) 5 cts., $1 / 4$ ounce pkg. 15 cts.

\section{Everlasting or Straw Flowers}

Also called Immortelles. An interesting class of annuals, producing an abundance of straw-like flowers. When dried they retain their bright colors indefinitely. Largely grown for winter bouquets. Large packets containing a mixture of Ammobium Helichrysum, Globe Amaranth or Gomphrenia Rhodanthe, Xeranthemum, etc. Large Pkt. 10 cts.

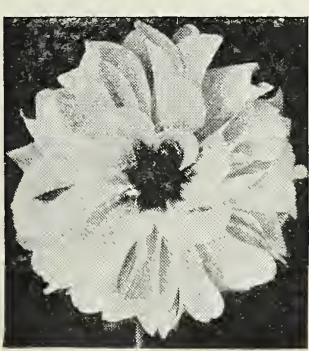

Single Dahlias
180 Dahlia New Single. These beautiful new single Dahlias are very easily grown from seed, and will produce an abundance of flowers in many colors the first year. After the frost kills the tops, dig up the roots and store them in the cellar. Pkt. (50 to 75 seeds) 3 cts.

181 Ice Plant Mesembryanthemum. of low, trailing habit. The foliage and stems are covered with crystal-like formations that glisten in the sun. Useful for hanging baskets and vases. Of easy culture. Pkt. (500 or more seeds) 3 cts.

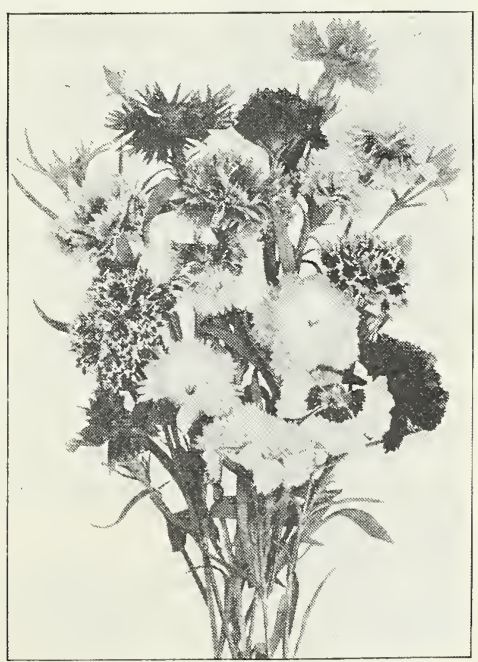

China and Japar Pinks 


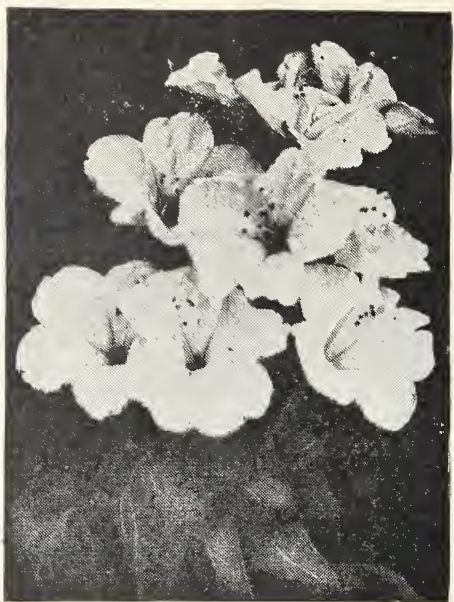

Four O'Clocks

\section{Four O'Clock}

182 Marvel of Peru One of the most popular and desirable annuals, of the easiest culture. Fine for hedges between seeds) 3 cts., ounce pkg. 20 cts.

We sold 57,000 packets of Four O'Clock seed in 1920.

\section{Forget-Me-Not}

Dainty, elegant little flowers, that bloom the first Season, living over winter and blooming profusely the second year. They love a shady moist place. Once at home in the garden they establish themselves by self-seeding. Every garden should contain a clump of these pretty flowers. Pkt. $(500$ seeds) 3 cts.

\section{Larkspur}

184 Annual Quick-growing, free-flowering anflowers in great abundance. A mixture of various types and colors including Emperor, Hyacinth-flowered Dwarf Rocket, Candelabra, etc. Pkt. (300 to 400 seeds) 5 cts.

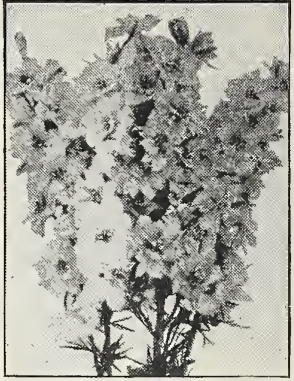

Larkspurs
185 Love-in-a-Mist $\begin{gathered}\text { Nigella. } \\ \text { Compact. }\end{gathered}$ free-flowering annuals with pretty, white and light blue flowers nestled among the feathery foliage, and curious seed-pods. Pkt. 3 cts.

186 Mourning Bride $\begin{gathered}\text { Scabiosa. } \\ \text { Alsocalled }\end{gathered}$ "Pin-Cushion Flower." Easily grown, desirable annuals, blooming until cut down by frost. Many colors. Pkt. 3 cts.

\section{Mignonette}

No garden is complete without at least a small bed of Mignonette. It is a well known fragrant annual of easiest culture. Successive sowing should be made to keep up a supply of flowers from Spring until frost.

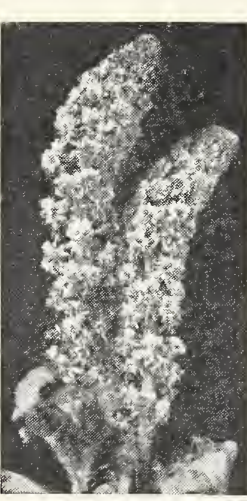

Mignonette

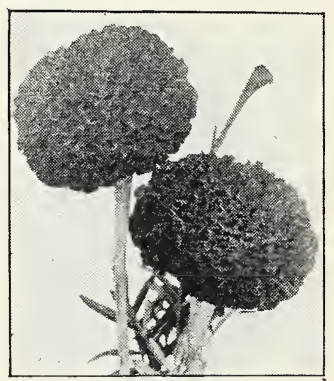

African Marigolds

\section{Marigold}

\section{African and French}

The African has very large double, yellow and orange flowers. The French type is more dwarf, with smaller flowers. Each packet contains both varieties, which may be separated when transplanting. Pkt. (150 or more seeds) 3 cts.

189 Dwarf Marigold Legion of Quite dwarf in habit; fine for borders. Pretty single brown and yellow flowers all summer. Pkt. (about 150 seeds) 3 cts. ture of several best varieties. Pkt. (about 500 seeds) 3 cts., 1/2 ounce pkg. 15 cts.

\section{Nasturtiums}

For summer display in large or small beds, nothing can surpass Nasturtiums. They start to bloom early and keep up a continuous display of bright colored flowers until hard frost in fall. Nasturtiums are much used for table decoration. Of the easiest culture, succeeding practically anywhere, blooming most freely on lighter soil. If we were compelled to grow but one variety of annual flowers, it would be NASTURTIUMS.

We do not have the room, or desire to offer a long list of named varieties. We list only the various types, finest mixture in each type as follows:

190 Dwarf Nasturtiums Specially desirable for or driveways, forming bordering beds, walks Always in bloom from June to October. A splendid mixture comprising many varieties and colors. Pkt. 5 cts., large ounce pkg. 20 cts.

191 Tall or Climbing For trailing over porch lattice or arbors, or for covering old fences or unsightly places, also for vases, we consider the tall varieties most desirable. There is also a greater variety in colors, including the brilliant Lobbianum type. Mixture, including all types. Pkt. (40 to 50 seeds) 3 cts., large ounce pkg. 15 cts.

192 New Ivy Leaved A desirable new type of Climbing Nasturtiums, white and distinct brilliant colored frin bright green Ivy-like foliage, veined with ounce pkg. $15 \mathrm{cts}$.

193 New Tall Variegated Each leaf is irregularly variegated and marplant a varied aspect. A mixture of several varieties. Pkt. (25 to 30 seeds) 5 cts. $1 / 2$ ounce pkg. 10 cts.

194 Lilliput or Baby Dwarf Miniature compact little plants of the a few inches high and comprising many beautiful varieties. Unsurpassed for borders. Pkt. ( 25 to 30 seeds) 8 cts., $1 / 2$ ounce pkg. 15 cts.

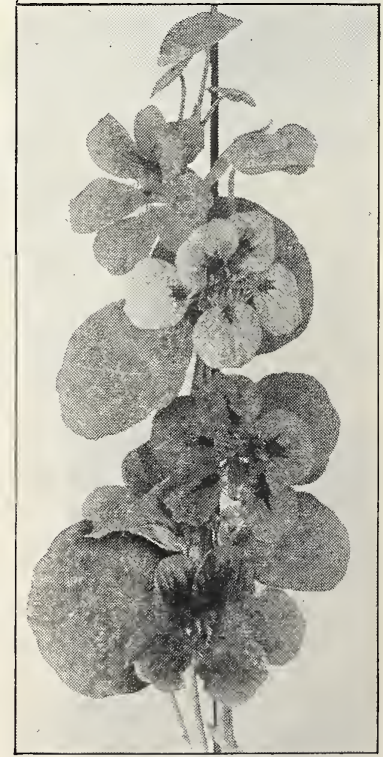

Tall Nasturtium 


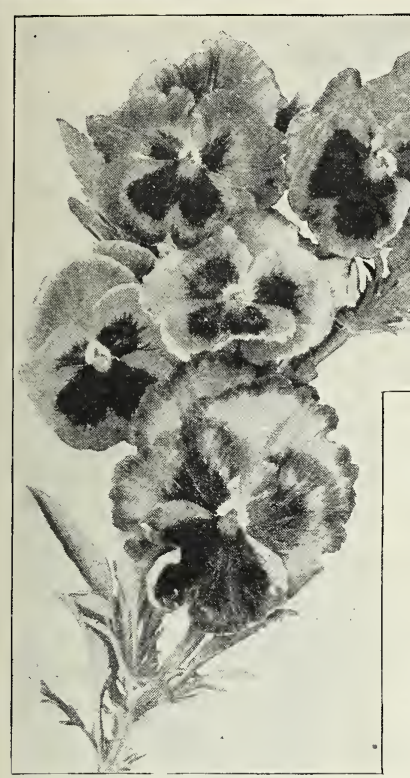

Pansies

\section{Pansies}

Pansies are general favorites, too well-known to require any description. We believe we can best serve our patrons by offering the seeds in only three grades, rather than to list them in separate named varieties. The following are the three grades or types.

195 Bedding Mixture These are the popular saucyloves, comprising about fifty varieties of English and German Pansies of the medium sized free flowering type. Just what you want for a pretty bed. We buy the named varieties and mix them ourselves. You will be delighted with this mixture. Pkt. about 250 seeds, 5 cts., $1 / 8$ ounce pkg. 30 cts.

196 Giant Trimardeau This is the popular medium priced large flowerand are grown in 25 or more named varieties. The flowers are much larger than our Bedding Mixture but not quite as free flowering. A splendid mixture, comprising many beautiful varieties. Pkt. about 150 seeds, 5 cts., 1/8 ounce pkg. 40 cts.

\section{7 \\ Giant Exhibition Pansies}

\section{"THE BEST THAT MONEY CAN BUY"}

In order that our patrons may have the pleasure of growing some of the very best Pansies in existence at a nominal expense, we contracted a year ago with the best known Pansy Specialists in Europe to grow us a quantity of each of the following Bugnot's Superb Giant Blotched, Giant Bridesmaid, Giant Bronze Colored, Cassiers 3 and 5 Blotched Giants, Giant Cardinal, Giant Daybreak, Emperor Franz Joseph. Giant Fire King, Giant Hortensia Red, Madam Perret or Phenomenal, Masterpiece or Ruffled Giants, Giant Mauve Queen, Odier Five Blotched, Giant Orchid Flowered, Parisian Giant Stained, Giant President McKinley, President Carnot, Giant Striped and Mottled, etc. We are not going to ask you to buy a packed of each variety, but have included all of the above varieties in a well-balanced mixture, so that you may enjoy all of these beautiful varieties by ordering only one packet. Price Pkt. 125 or more seeds, 15 cts., 2 pkts. 25 cts., 5 pk ts. 50 cts.

$198 \mathrm{Y} / 8 \mathrm{OZ}$. package of the above mixture $90 \mathrm{cts}$.

\section{Petunias}

199 Petunia Hybrida For an abundance of large showy flowthroughout the entire summer and tions are, they are always in bloom. We list them in choicest mixture, comprising many colors. Pkt. 5 cts., $1 / 8$ ounce pkg. 25 cts.

200 Rosy Morn Compact bushy plants, flowers medium size. the entire summer. Color a most pleasing clear pink with large pure white throat. Fine for porch boxes, etc. Pkt. 10 cts.

201 Howard Star A beautiful type, having crimson maroon white. Fine for vases, baskets, bedding, etc. Pkt. 10 cts.

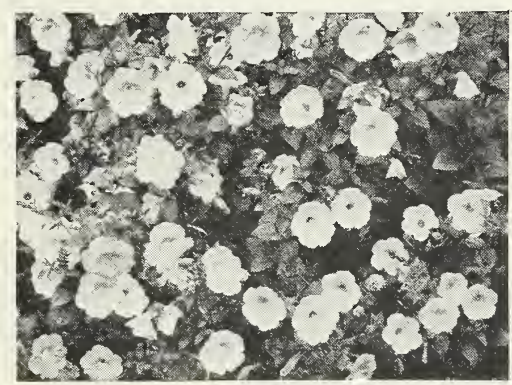

Petunia Hybrida

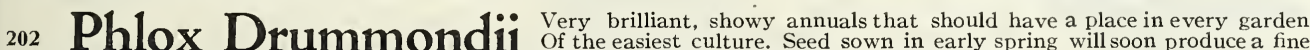
display of many bright colors. Pkt. 5 cts.

\section{Poppies}

203 Double and Single For a brilliant dazzling effect nothing early in the spring, where they are to bloom, as they cannot be transplanted. We offer them only in our grand mixture of many types and colors. We order the various types and named varieties separately and mix them ourselves. You will be delighted with them. Pkt. 5 cts., $1 / 4$ ounce pkg. 10 cts.

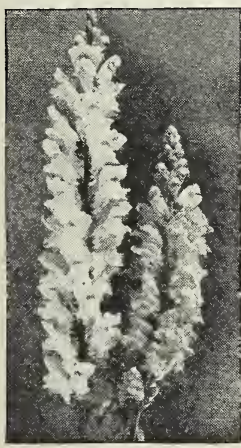

Snapdragon 204 Painted Daisy an the mum. annuals, forming large bushy plants, with a prof usion of showy flowers. The single varieties have daisylike flowers, the petals beautifully painted or stained. Very attractive. Pkt. 5 cts.

\section{Portulaca (Rose-Moss)}

205 Single Mixed of very easy culture, requiring bright sunshine and producing a dazzling carpet-like effect all summer. Pkt. 3 cts.

206 Finest Double A beautiful type hav. flowers in greatest profusion. Many colors mixed. Pkt. 10 cts.

\section{${ }_{207}$ Snapdragon (Antirrhinum)}

spikes of flowers throughout the summer and autumn. If carefully lifted and potted in September, they will bloom in the house during the early winter months Finest mixed colors. Pkt. 5 cts.

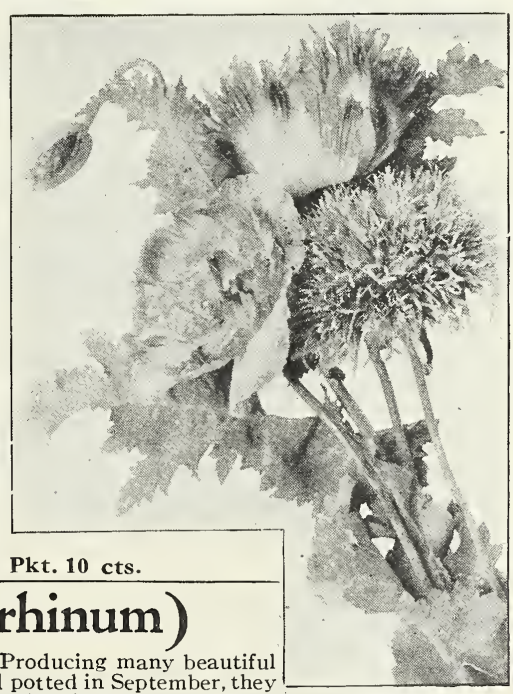


Sweet Peas

For distinctive beauty and exquisite fragrance the Sweet Pea has no rival. We sell more packets of Sweet Peas annually than any other flower. Last season more than a quarter million packets were ordered, requiring about three thousand pounds of seed. We have five thousand pounds ready to fill orders this year. We do not offer them in distinct named varieties; only in mixtures of the various types as follows:

208 Grandiflora or Large Flowering. An extra fine, well-balthat is so popular anced mixture of the popular large-flowering type (1) insure a more complete mixture connumber of varieties, we combine the best from several different growers. Sure to please you. Pkt. 5 ets., ounce pkg. 15 cts., $1 / 41$ 1b. 35 cts.

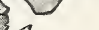

209 Spencer or Orchid Flowering. This is the new ruffled or larger than the Grandiflora class, the petals beautifully ruffled or frilled. A good mixture containing many varieties. Pkt. (100 seeds) 8 cts., $1 / 2$ oz. pkg. 15 cts. 210 Extra Quality Giant Spencer Sweet Peas ${ }_{\text {that our }}^{\text {In order }}$ patrons may enjoy growing the very finest there is in ruffled or frilled Sweet Peas, we have made up a mixture including many of the very best up-to-date named varieties, representing the highest achievements in both size and equisite colors. This mixture will give a magnificent display. Pkt. ( 75 seeds) 15 cts., $1 / 2$ oz. pkg. 25 cts. 211 "Baby" Cupid Sweet Peas An entirely distinct type, growSuitable for borders. Flowers large and fragrant. Choice mixture. Pkt. (about 50 seeds) 3 cts.

\section{${ }^{212}$ Ten Week Stocks}

Sweet Peas

One of the best known and most popular annuals, of easy culture, and suitable for pots as well as garden culture. Beautiful spikes of flowers in many distinct colors. Several varieties including the perpetual "Cut and Come Again" type. Packet (200 or more seeds) 5 cts.

\section{${ }^{213}$ New Annual Sweet William}

A valuable new annual blooming type of the popular Sweet William, originated by crossing the common Perennial variety with the Annual Japan Heddiwigii Pink. The flowers are much larger and are produced in clusters throughout the Summer and Autumn. Many beautiful colors mixed. Pkt. 10 cts.

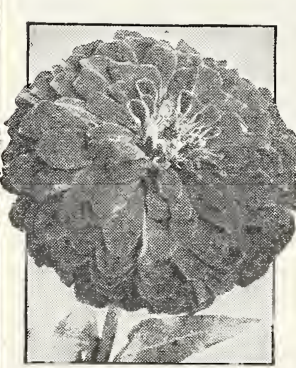

Giant Zinnia

\section{Verbenas}

214 Mammoth Flowering Very free-flowering annuals of a carpet of bright colors when in bloom. Begin to bloom in July, and continue until killed by frost. Choice mixture, including the Mammoth, or largeflowering type. Pkt. (about 200 seeds) 3 cts.

\section{Zinnias}

215 Giant Zinnia The popular Zinnia or "Youth and Old Age"

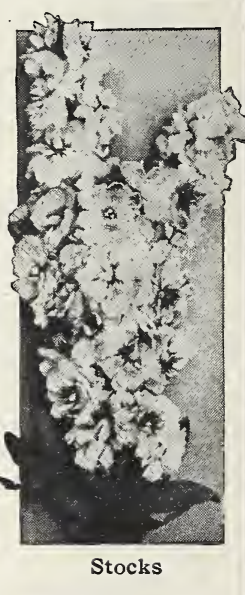
marvels of size and perfection in form and colors. Finest mixture that will produce very large flowers. Pkt. 10 cts.

216 Zinnia Elegans $\begin{gathered}\text { Double smaller flowering varieties in many colors. Very profuse } \\ \text { bloomers and perfectly double flowers. Pkt. } 3 \text { cts. }\end{gathered}$

\section{Climbing Vines}

217 Balloon Vine "Love-in-a-Puff". Pretty climblike seed-pods. Pkt. (40 to 50 seeds) 5 cts.

218 Cardinal Climber New Hybrid Cypress Vine. large brilliant cardinal red flowers. Pkt. 10 cts.

219 Cypress Vine Delicate, fern-like foliage and 8 feet. Pkt. (about 40 seeds) 3 cts.

22 Hyacinth Bean Strong, rapid climber, with resembling the Hyacinth. Pkt. (40 to 50 seeds) 3 cts.

221 Ipomoea Japanese Morning Glory. Very rapid flowers of rare beauty. Pkt. (50 to 75 seeds) 5 cts.

222 Morning Glory Too well known to need decovering old fences, arbors, etc. Splendid mixture. Pkt. (200 seeds) 3 cts., ounce pkg. 12 cts.

\section{Hardy Perennials}

223 Canterbury Bells or Campanula. Wellin known old garden favorite. Showy, large "bellfiowers" in greatest p.
and July. Pkt. (500 or more seeds) 3 cts.

224 Foxglove or Digitalis. Tall spikes of very showy Pkt. (about 600 seeds) 3 cts.

225 Hollyhock Old-fashioned, tall, stately, dignified  Extra large flowering. Single, many colors. Pkt. (50 sds.) 5 cts. 226 Shasta Daisy like flower. 3 inches across on long stems. Very desirable. Pkt. 5 cts.

227 Sweet May Pinks "Clove or Scotch Pinks". Sinks "Every garden should have a few clumps of these popular flowers. Single and double, all colors, mixed. Pkt. (200 seeds) 5 cts.

228 Sweet William Needs no description. Very little attention. Mixed colors. Pkt. (about 250 seeds) 3 cts. 


\section{A MILLION GLADIOLI BULBS}

\section{AT PRICES WITHIN REACH OF EVERYBODY}

Gladioli are the most useful of all Summer flowering bulbs, and are becoming more and more popular each year as new varieties are being introduced. They are so easily grown, and at our prices so inexpensive, that every home garden should contain an assortment. Gladioli are one of our specialties. We now have in stock a million or more blooming size bulbs, all clean, healthy stock, ready to fill orders. All named bulbs will be $1 \frac{1}{8}$ to $1 \frac{1}{2}$ inches and up in diameter and guaranteed to produce beautiful large spikes of flowers this year. We grew all the bulbs offered on this page.

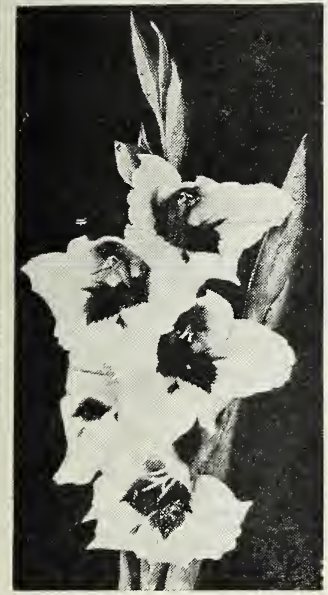

Mrs. Frank Pendleton

\section{Best Six New Gladioli} 301 Mrs. Frank Pendleton One of the most and finest formed Gladioli in exquisitely colored, Color delicate blush pink, with large, brilliant crimson blotches on lower petals. Extra fine. Each 8 cts., 4 for 30 cts. 302 Niagara $\begin{aligned} & \text { A charming variety. Flowers very large, } \\ & \text { delicate cream-yellow, splashed with car- }\end{aligned}$ mine-rose in the throat. Each 8 cts., 4 for 30 cts.

303 Panama A grand new variety, which evokes words inerer exhibited. Flower and 304 Peace A grand white flower, of large size, with deli304 Peace cate lilac feathering on lower petals. Splendid tall, graceful spikes. Each 7 cts., 4 for 25 cts.

305 Schwaben Very vigorous, producing tall spikes bet fifteen to twentylarge flowers. The low. Each 8 cts., 4 for 30 cts.

306 War The largest and best of the dark reds. ExtraW large spikes. Deep blood-red, shaded maroon. Sure to please. Each 8 cts., 4 for 30 cts.

307 Set of Six Best Gladioli for 40 cts. 3 Sets for $\$ 1.10$.

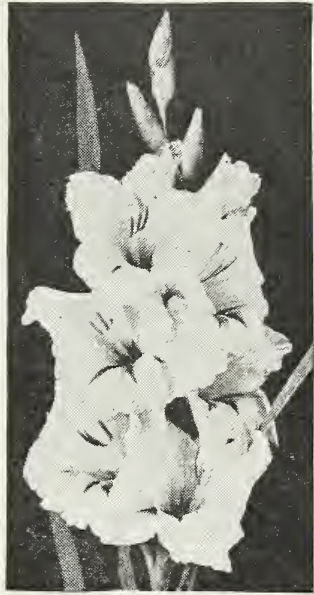

Schwaben

\section{Twelve of the Most Popular Named Gladioli}

308 America Unquestionably the most Popmense spikes, color delicate peach-blossom pink. Each 5 cts., 6 for 25 cts.

309 Anna Wigman $\begin{aligned} & \text { Large spikes. Color } \\ & \text { canary yellow, with }\end{aligned}$ crimson blotches on lower petals. Very desirable. Each 6 cts., 5 for 25 cts.

310 Augusta Early flowering and very vigbluish shadings. Large well-formed spikes. Each 5 cts., 6 for 25 cts.

311 Baron Hulot Very dark violet blue. on tall spikes. Entirely distinct in color. Each 7 cts., 4 for 25 cts.

312 Brenchleyensis Deep vermilionmarkings on lower petals. One of the finest for the garden. 5 cts., 6 for 25 cts.

313 Halley Extra early. Delicate salmonblotched creamy white. Each 6 cts., 5 for 25 cts.

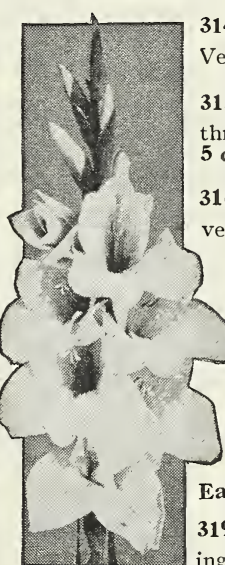

Panama

314 Ida Van Brilliant cardinal red, deeper in the Very desirable. 6 cts., 5 for 25 cts.

315 Independence Rich begonia-pink with throat. Tall spikes of wax-like flowers. One of the best. 5 cts., 6 for 25 cts.

316 Mrs. Francis $\mathbb{K}$ ing A most beautifu ermilion shadings. Immense flowers on spikes, 3 to . 25 cts.

317 Primulinus Hybrids A distinct South Africa crossed with our popular varieties. Extra early, delicate shades of yellow, buff, fawn, primrose, etc., heretofore unknown in Gladioli. Each 5 cts., 6 for 25 cts. 318 Princepine A beautiful, distinct variEach 5 cts., 6 for 25 cts.

319 Sulphur Queen Pure canary-yellow with ings on lower petals. One of the best yellow varieties. Each 6 cts., 5 for 25 cts.

320 Set of 12 Most Popular Varieties, Not Labeled, for 50 cts.

\section{Superfine Mixed Gladioli Bulbs}

To those who want a choice assortment of Gladioli, at a nominal expense, and do not care for the named varieties, we recommend our Superfine Mixture, which we sell by the hundred thousands. This mixture is made up from the above and many other varieties which we grow under name. Also Groff's Hybrids, Childs' Lemoineii, Naucianus, Primulinus Hybrids, etc., which we grow in separate mixtures, and include in our Superfine Mixture. A combined mixture that we do not hesitate to recommend. We offer them in two sizes as follows:

321 Ist Size In size from $1 \frac{1}{8}$ to $1 \frac{1}{2}$ inch and up in duce a fine large spike of flowers this year. 12 for 30 cts. 50 for $\$ 1.10$.
322 2nd Size Size about $7 / 8$ to 1 inch in diameter. teed to produce a nice spike, but not quite as large as the 1st size. 12 for 20 cts., 50 for 75 cts. 


\section{QUALITY DAHLIAS}

It is useless to attempt to keep pace with the development of the hundreds of new varieties that are being introduced by Dahlia Specialists. In accordance with our established policy we have again selected just a few of the most distinctly beautiful varieties in the various types. In the Summer of 1919 we went carefully over several acres containing more than one hundred varieties then in bloom, and selected the following varieties, placing our order then for delivery in 1921, giving the grower time to produce these varieties in sufficient quantities to supply our growing demand. We are prepared to supply up to one hundred thousand or more.

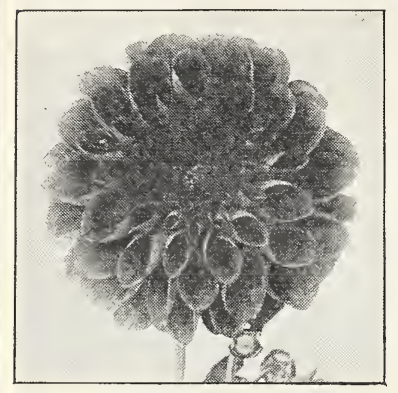

Decorative Dahlia

\section{Decorative Dahlias}

333 Mirs. J.G. Cassatt $\mathrm{traw}_{\text {tralare }}^{\mathrm{Nex}}$ perfect double. Color soft pink with lavender shadings. Very profuse bloomer. 20 cts.

334 JackRose Medium large and unitense brilliantcrimson. Anoldstandby. Noth ing better has yet been invented. 15 cts. 335 Princess Juliana Holland Finest white decorative for cut flowers. Received Holland first Class Certificate. 20 cts.

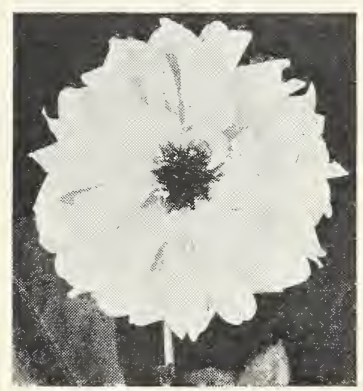

New Peony Dah!ia

\section{Cactus Dahlias}

330 Cockatoo A distinct novelty. Pure white variegated flowers often on the same plant. Always attracts attention. 20 cts.

riemhilde Delicate sort rosy-pink shadDistinct Cactus type. Very desirable. 15 cts.

32 Harbor Light vivid, velvety, orangeFlowers large and freely produced on long tems. One of the best Cactus. 15 cts.

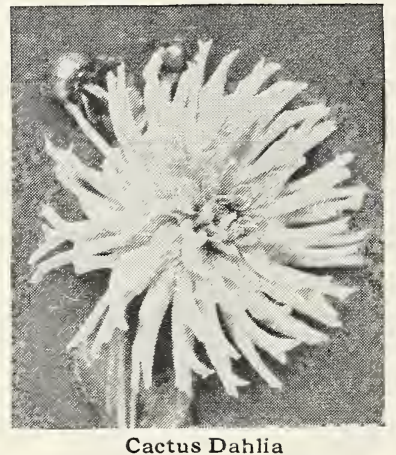

\section{Pompon Dahlias}

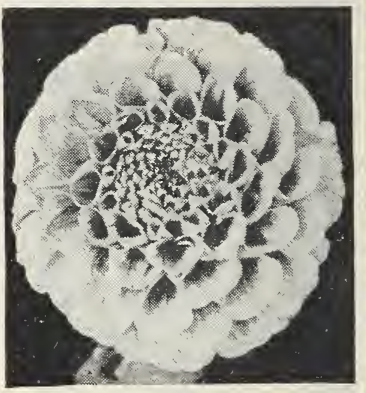

Show Dahlia

\section{Show Dahlias}

336 A. D. Livoni Extrafine. Very Largely grown for cut flowers. Color clear light cerise-pink. 15 cts.

337 Cuban Giant One of the largperfectly double Dahlias in existence. Color dark velvety crimson. Always attracts attention. 20 cts.

338 White Swan Medium-large, Very double. Color pure snow white. Free bloomer. Fine for cut flowers. 15 cts.

339 Bride Pure white perfectly double little balls, on 339 Bride long stems. A very profuse bloomer. Fine for cut flowers. $15 \mathrm{cts}$.

340 Fairy Oueen Perfectly double little flowers, edged and tipped coppery-red. Very free bloomer. 15 cts. 341 Prince Charming Creamy white, very heavlight purple-rrimson. Perfect little balls in abundance. 20 cts.

\section{New Peony Dahlia}

342 Mrs. Keeling Semi-double, large irregular petand striped with old gold. A distinct new type. $20 \mathrm{cts}$. each. 343 Above Set of 13 Dahlias for $\$ 1.75$

${ }_{344}$ Choice Mixed Dahlias

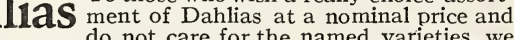

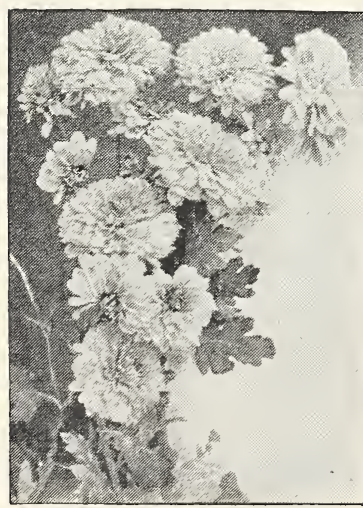
Pompon, etc. They will be carefully mixed in a manner to insure the greatest possible variety in types and colors, but

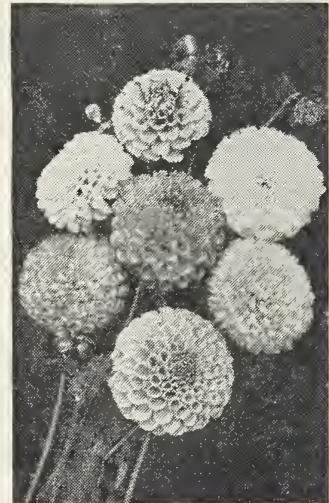

Pompon Dahlia 50 cts. 12 for 90 cts. prepaid.

\section{Old Fashioned Hardy Garden Chrysanthemums}

The well-known Autumn flowers of our Grandmothers gardens that produce such an abundance of flowers at a time when they are so much appreciated. Last season we sold seventyfive thousand plants in four varieties. This season we have added a new everblooming variety and have told our grower we would want one hundred thousand, as follows:

345 Glory of Seven Oalzs The Ever-blooming Hardy "Mum". Commence to Pretty double bright-yellow flowers. Very desirable. 15 cts.

346 Golden Climax Vigorous compact growth and a profusion of golden yellow

347 Indian Chief Coppery red, shaded brilliant crimson. Very double and a pro-

348 Old Homestead Beautiful, free flowering, bright rose-pink. Large double.

349 Victory Popular, hardy, large, double, pure snow-white. Fine for cemetery 350 Set of Five Hardy "Mums" not Labeled for $50 \mathrm{cts}$. 


\section{LARGE FLOWERING CANNAS}

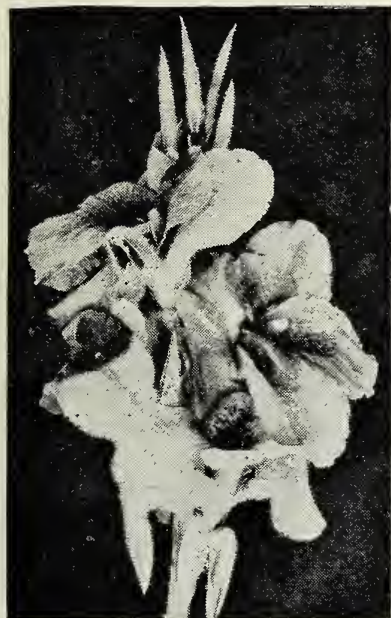

King Humbert

For beds on the lawn, where a tropical effect is desired, we know of no plant so satisfactory. There are a hundred or more varieties in cultivation. We have selected just a few of the best and most distinct types and colors. We handle them only in dormant roots, which may easily be started in a box in a warm room, or in a hot bed.

\section{The Two Best Cannas}

The following two Cannas are generally considered the best in existence

360 King Humbert "Ghis wonderful Canna has been the attraction wherever grown. Dark bronze foliage and immense, bright orangescarlet flowers and very large trusses. Height 4 feet. 15 cts., 12 for $\$ 1.50$. 361 Queen Helen Yellow HumKing Humbert, having plain green foliage and enormous flowers 5 to 6 inches across. Color Golden Yellow, dotted and blotched bright-red. An occasional scarlet flower will sometimes appear. 15 cts., 12 for $\$ 1.50$.

362 Two Best Cannas for 25c.

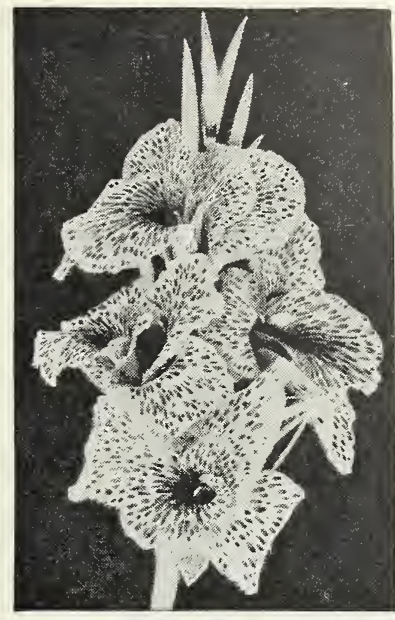

\section{Large Flowering Bedding Cannas}

363 Buttercup The best Dwarf Yellow. Flowers pure cts. each, 12 for $\$ 1.25$,

364 Crimson Bedder Height $31 / 2 \mathrm{ft}$. Green foltrusses of intense crimson flowers. One of the best. 12 cts. each, 12 for $\$ 1.25$.

365 Gladiator Height $4 \frac{1}{2} \mathrm{ft}$. An excellent bedder, and large golden yellow flowers, freely dotted with crimson. $12 \mathrm{cts}$. each, 12 for $\$ 1.25$.
366 Madam Crozy ${ }_{31 / 2} \mathrm{ft}$. Immense trusses of brilliant vermilion scarlet with narrow edge of golden yellow. 12 cts. each, 12 for $\$ 1.25$.

367 Venus an exceedingly beautiful Canna. Color Large trusses of well formed flowers, green foliage, height $4 \mathrm{ft}$. 12 cts. each, 12 for $\$ 1.25$.

368 Austria $4 \frac{1}{2} \mathrm{ft}$. (Orchid Flowering). Large broad 5 inches across. Color bright lemon yellow, base of petals dotted with crimson. $12 \mathrm{cts}$. each, 12 for $\$ 1.25$.

369 Set of 6 Bedding Cannas, labeled, for 65 cts. 12 for $\$ 1.25$. 370 Set of 6 Bedding Cannas, not labeled, for $50 \mathrm{cts}$., 12 for 90 cts.

\section{Miscellaneous Summer Flowering Bulbs}

371 Caladium Elephant's Ear. Immense tropical-like foliage. Very effective as single plant or 372 Caladium, Elephant's Ear, Large Bulbs $25 \mathrm{cts}$.

373 Cinnamon Vine Rapid climbing hardy vine, glossy green foliage and a profusion of small 374 Hyacinth Candicans Yucca-like foliage and tall spikes of pure white pendant, fragrant 375 Madeira Vine One of the best climbing vines for foliage effect, glossy green foliage. Rapid 1 Madeira 1 ine climber to height of $20 \mathrm{ft}$. $10 \mathrm{cts}$., 4 for 25 cts.

376 Oxalis Summer Flowering. Sometimes called "Shamrock." Useful for edging beds, blooming - continually, mixed colors, white, red and pink. 12 for 20 cts., 50 for 50 cts.

\section{Tuberoses Double and Single}

377 Double Dwarf Pearl No flower is more fragrant than the Tuberose. It is of very easy and September. Extra large first size bulbs 8 cts., 2 for 15 cts., 6 for 40 cts., 12 for 75 cts. 378 Mexican Tuberose $\begin{aligned} & \text { Pure waxy white single fragrant flowers on tall stiff stems. Very } \\ & \text { perpetual bloomer of very easy culture. } 8 \text { cts., } 4 \text { for } 25 \text { cts. }\end{aligned}$
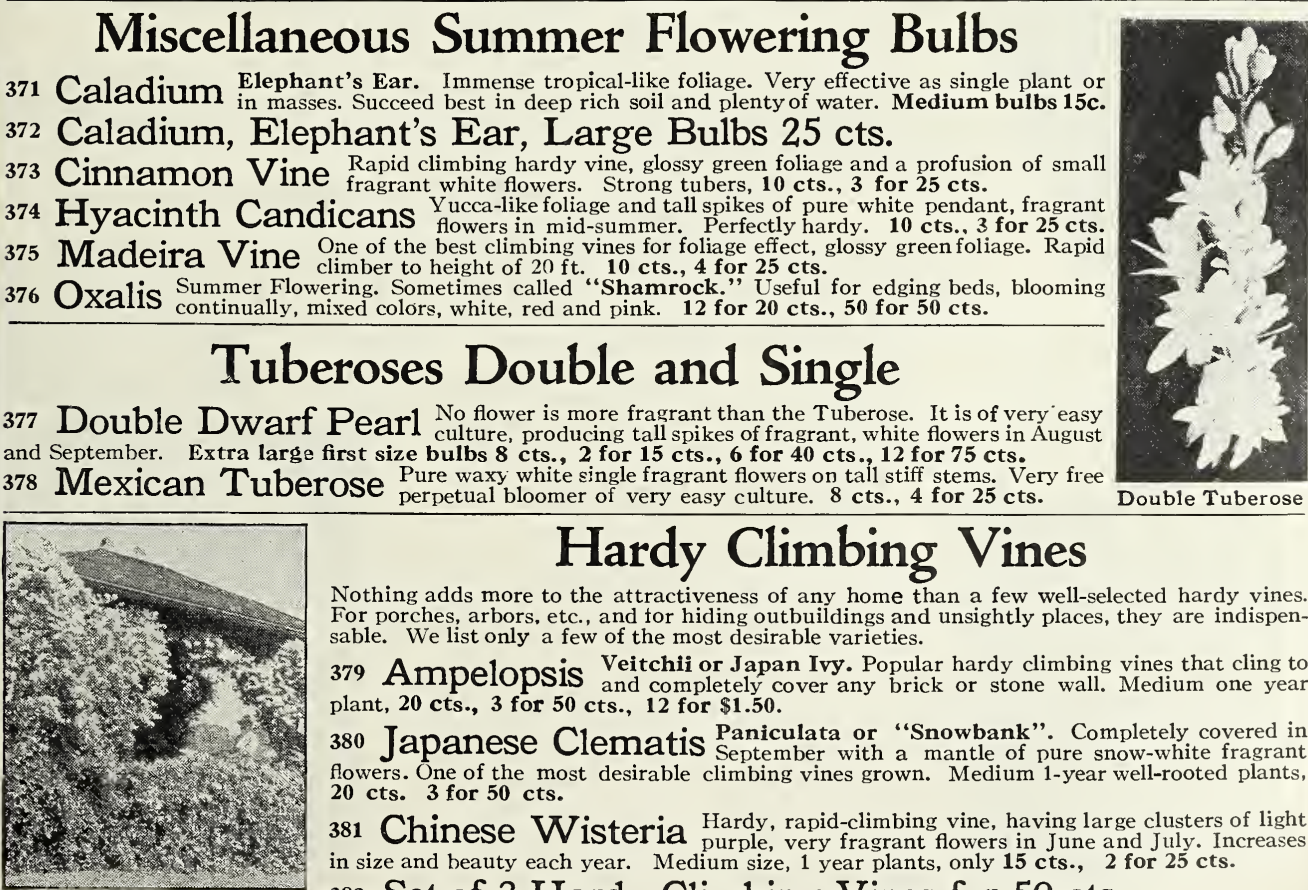

\section{Hardy Climbing Vines}

Nothing adds more to the attractiveness of any home than a few well-selected hardy vines. For porches, arbors, etc., and tor hiding outbuildings and unsightly places, they are indispensable. We list only a few of the most desirable varieties.

379 Ampelopsis Veitchii or Japan Ivy. Popular hardy climbing vines that cling to plant, 20 cts., 3 for 50 cts., 12 for $\$ 1.50$.

380 Tapanese Clematis Paniculata or "Snowbank". Completely covered in flowers. One of the most desirable climbing vines grown. Medium 1-year well-rooted plants, 20 cts. 3 for 50 cts.

381 Chinese Wisteria Hardy, rapid-climbing vine, having large clusters of light in size and beauty each year. Medium size, 1 year plants, only 15 cts., 2 for 25 cts.

Clematis Paniculata 382 Set of 3 Hardy Climbing Vines for $50 \mathrm{cts}$. 


\section{HARDY HERBACEOUS ROOTS}

No home is complete without a well-selected assortment of hardy roots. They require so little attention and increase in size and beauty from year to year. Everything listed on this page is perfectly hardy, and our prices will be found very reasonable when quality is considered.

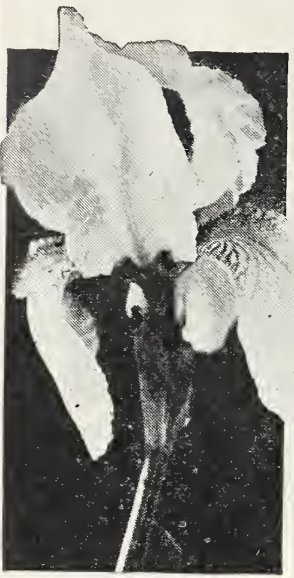

Butterfly Iris
Butterfly or

or "Lily of France"

Very popular, old-fashioned, hardy garden favorites, requiring little attention. Splendid for permanent borders along the driveway or edge of shrubbery. They are so cheap that everybody can afford to grow them. We have selected four of the most distinct and desirable varieties as described below. We know of no plant more easily grown and requiring so little care. 385 Mrs. H. Darwin Llowers. Clear waxy white, lower petals veined violet. Each 10 cts. 386 Honorabilis Standards golden yellow, effective. Each 10 cts. 387 Mme. Chereau Pure white, broadly blue. Very beautiful. Each 10 cts.

388 Othello Falls dark velvety purple. S 389 Set of 4, not labeled, $35 \mathrm{cts}$. JapaneseIris(Kaempferi) across on stiff stems. 3 to 4 feet high. Bloom throughout July.

390 Gold Bond Semi-double, six petals, very large pure snow-white with 390 Gold Bond golden-yellow band and base. 15 cts., 2 for 25 cts.

391 Mahogany other Iris. Very attractive. Price 20 cts.

392 Purple and Gold Immense, semi-double, 6 to 8 inches across, rich 393 The 3 Beautiful Japanese Iris for 45c, postpaid.

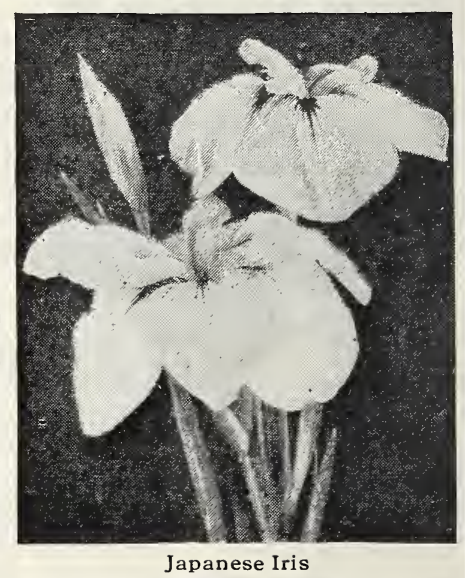

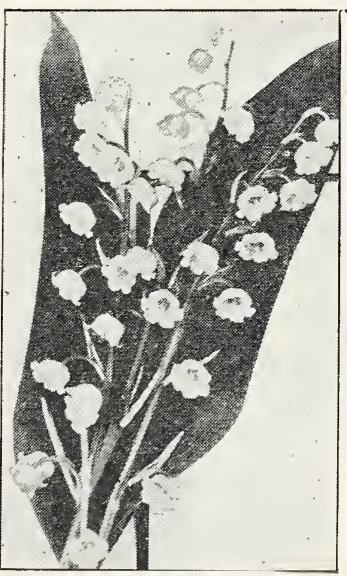

Lily of the Valley

\section{${ }_{394}$ Delphinum Belladonna}

The beautiful Belladonna, Hardy Larkspur, with its large spikes of clear sky-blue flowers is a universal favorite. We have been fortunate in securing a few thousand strong blooming roots of the improved large flowering type, from a specialist who grows them in large quantities. They bloom continually from July to frost. Price only 20 cts., 3 for 50 cts.

\section{${ }_{395}$ Lily of the Valley}

Universally admired for their dainty little pure white bell shaped flowers and exquisite fragrance. Easily grown, perfectly hardy everywhere, preferring a moist shady location. We have 150,000 fine Holland grown plants ready to fill your orders. 3 for 15 cts., 12 for 45 cts., 50 for $\$ 1.50,100$ for $\$ 2.75$.

\section{Meehan's Mallow Marvels}

The most valuable acquisition in hardy Herbaceous plants introduced in recent years. Forms large plants or clumps 5 to 6 feet high and 3 to 4 feet across blooming prof usely from July to late fall. Immense single flowers 6 to 8 inches across in the most beautiful colors, from white through various shades of pink and red to brilliant crimson. From 50 to 60 per cent will produce the brilliant red and crimson flowers. We however cannot supply them in separate colors. (See back cover.)

399 Strong 1-yr. Roots, 20c each, 3 for 50c, 12 for $\$ 1.50$. 400 Extra 2-yr. Roots, ${ }_{3}^{35}$ for $\$ 1.00$.

\section{Three Best Chinese Peonies}

First of all in the list of hardy plants for size and beauty. As hardy as an oak, forming large clumps or bushes. Should be in every garden in the land. A millionaire can have nothing finer, and no flower will succeed better for the common gardener. There are hundreds of named varieties and the list is still growing. It is useless to try to keep up with the procession. We have selected just three of what we consider the very best in the acres that we have seen when in bloom, including red, white and pink as follows: 401 Duchesse de Nemours $\begin{aligned} & \text { Large very double pure white with sulphur } \\ & \text { shadings in the depths. Early. Vigorous, form- }\end{aligned}$ ing large clumps, every stem producing a splendid flower. One of the very best. 40 cts. 402 Edulis Superba Large, loose, double crown. Color bright mauve-pink. grown for cut flowers for Decoration day, than any other variety. Each 40 cts.

403 Felix Crousse Large globular, perfectly double balls. Color intense brilliant bloomer. Generally considered the very best red Peony to date. Each 60 cts.

${ }_{404}$ The Set of Three Beautiful Peonies for only $\$ 1.25$.

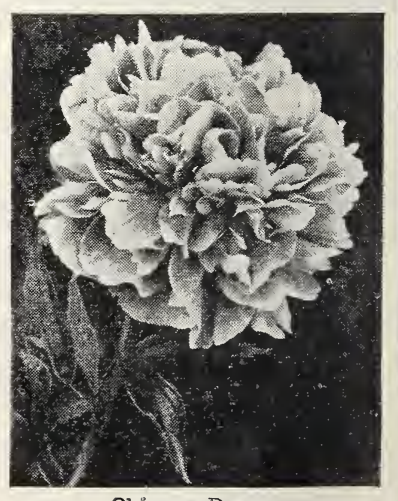




\section{HARDY ROSES AND SHRUBS}

Every home should be surrounded by a carefully selected assortment of hardy Roses and Shrubs. By this means a continual succession of flowers may be had throughout the season. Once established they require little attention, increasing in size and beauty from year to year. The following list has been selected with great care, and contains only varieties of real merit.

\section{Three Best Hybrid Perpetual Roses}

These are the beautiful "June Roses" so universally popular. They are the largest and richest in coloring of all Roses and perfectly hardy everywhere. There are a hundred or more varieties, but we confine our list to the best three as follows:

410 Frau Karl Druschki Everblooming White American Beauty. Extra 411 Gen'1 Jacqueminot The famous red garden rose. Large, double, fragrant, 412 Paul Neyron The largest rose in existence. Mammoth, full, double, fragrant 413 The Three Best Hybrid Perpetual Roses for $\$ 1.60$

\section{Ever Blooming Hardy Garden Rose}

414 Baby Rambler "Baby Doll Rose." Entirely distinct from all other Roses until frost. Pretty, little, Neat, dwarf, compact habit, in bloom continually from June Perfectly hardy, retaining its glossy green foliage all summer. One of the finest ever intro-

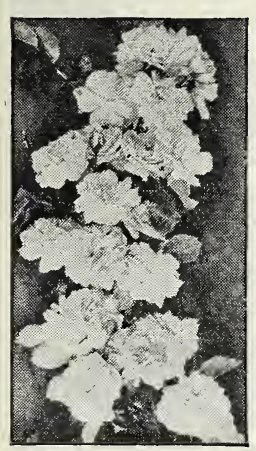

Dorothy Perkins duced. Each 40 cts. Two for 75 cts.

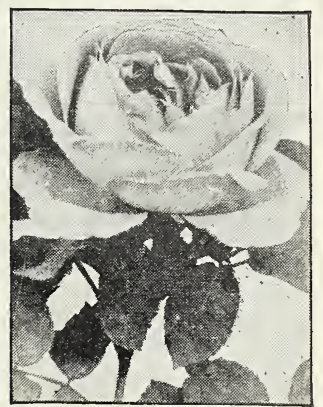

Paul Neyron

\section{The Two Best Hardy Climbing Roses}

415 Dorothy Perkins The original "Perkins" Rose, and the most popular pink climbing clusters of clear shell-pink double flowers. 35 cts.

416 Excelsa Crimson Perkins. Brilliant crimson, double flowers in immense clusters. Better subject to mildew. 35 cts.

417 The Two Best Hardy Climbing Roses for 65 cts.

\section{Hardy Flowering Shrubs}

421 Double Althea Rose of Sharon. Desirable hardy shrubs or small trees, easily grown as flowering hedges. Large, showy, double flowers in abundance from July to October. Extra strong 2 year plants, Double Red, 25 cts. each. 422 Extra strong 2 year plants, Double White, 25 cts. each.

423 Japanese Barberry $\begin{aligned} & \text { Berberis Thunbergii. Decidedly the most desirable and useful } \\ & \text { shrub in cultivation. Of neat, graceful dwarf habit, unequaled }\end{aligned}$ for ornamental hedges, for bordering clumps of larger shrubs, or grown as single specimens. More extensively planted than any other shrub. The fragrant yellow flowers are followed by scarlet berries that remain on the plants all winter. This variety is recommended by the U.S. Government. Wehandle only twoyear, field-grown, well-branched plants, 12 to 18 inches high. Each 15 cts., 12 for $\$ 1.25,100$ for $\$ 8.00$. 424 Calycanthus The old-fashioned fragrant "Shrub" so popular everywhere. Double vel-

425 Deutzia Pride of Rochester. A splendid Japanese shrub. Cluster of blush-white flowers 426 Forsythia Golden Chain. A profusion of golden yellow drooping flowers, before the leaves 426 Forsythia appear in Spring. 25 cts. each.

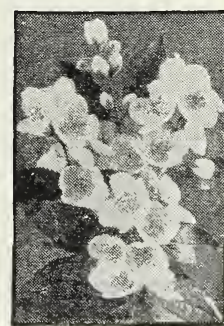

Mock Orange

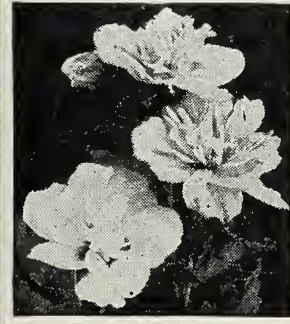

Double Althea

427 Bush Honeysuckle

Lonicera. Neat habit. Glossy green foliage and pretty bright red berries. 25 cts. each.

428 Hydrangea Paniculata Grandiflora. One of the most popular and best known of all the flowering shrubs. Immense panicles of white flowers from July to September, changing to greenish-pink. Grown as single specimen plants, in clumps with other
shrubs, or ornamental hedges, it always gives satisfaction. Height 4 to $5 \mathrm{ft}$. 1 year plants 15c. 429 Two year plants, 25 cts. each.

430 Mock Orange Popular shrubs growing 6 to 8 fragrant white flowers in June. 25 cts. each.

431 Snowberry Symphoricarpos. Neat shrubs of medflowers in June, followed by waxy white berries in Autumn and early Winter. 25 cts. each.

432 Spirea Anthony Waterer. Very desirable perpetual blooming shrubs forming bright rosy crimson flowers from June to to 24 inches high, with large flat corymbs of shrubs, for planting around porches, etc. Bushy 2 year plants, 25 cts., 12 for \$1.75.

433 Bridal Wreath Spirea Van Houttei. One of the most graceful and planting, in clumps or as single specimens. 1 year plants, 20 cts., 12 for $\$ 1.50$.

434 Strong, 2 year well-branched plants, 30 cts. each, 12 for $\$ 2.50$.

435 Weigela Rosea A beautiful shrub, the pretty pink bell-shaped flowers alplants, 30 cts.

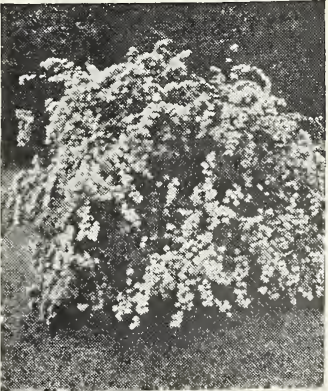

Bridal Wreath 


\section{A PAGE of SELECTED BERRY PLANTS}

We want our patrons to grow the very best varieties of Berries. We are not going to confuse you by offering a long list of varieties. We have therefore consulted a number of experienced growers, and as a result have selected the following varieties which we confidently believe to be the best in their respective classes. You can make no mistake by planting these varieties.

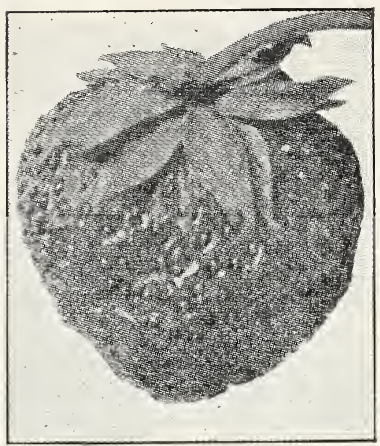

Gibson Strawberry

\section{The Best Strawberry}

440 Gibson In Berrien County, Michigan, the second largest Strawberry County the world, two thirds of all the Strawberries grown are the appearance. Gibson plants out-yield other varieties, and Gibson berries out-sell other berries on the market. This is certainly recommendation enough, but we want to add that it is also an extra nice table or home Strawberry. The plants are extra strong growers. They commence to ripen medium early and continue for a long season, making a heavy yield. Growers reported as high as $\$ 700$ per acre last season. Whether for home use or for market, you will make no mistake by planting Gibson.

Price Postpaid, 12 for 40 cts., 50 for 85 cts., 100 for $\$ 1.50$.

\section{The Best Red Raspberry}

441 Early King This is an extra early red Raspberry. It is a week or ten days very large, bright-red, firm and easily picked. The canes are strong and perfectly hardy. One grower says Early King is the earliest and most beautifu red Raspberry we have ever grown. As a market variety it is a money-maker as you get the early market ahead of the big shipment of other varieties. Price 3 for 25 cts., 12 for 85 cts., 50 for $\$ 2.75,100$ for $\$ 5.00$.

\section{The Best Black Cap Raspberry}

442 Cumberland The "BUSINESS BLACK CAP". Biggest black Raspberry is offered with the assurance that it is the most
profitable and desirable variety for home or market. Cumberland is very hardy everywhere. Extra

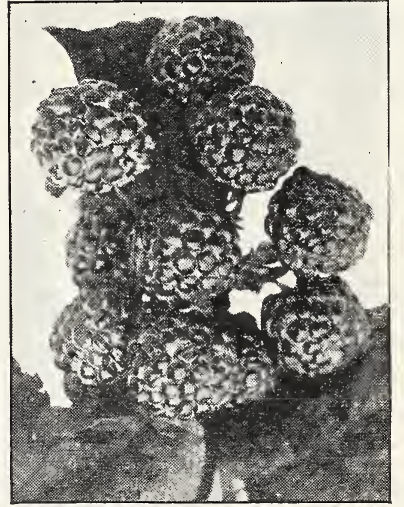

Cumberland Raspberry productive, being the heaviest bearing variety in cultivation. Fruit is extra large, jet black, and of superior quality. Ripens medium early. This is the Standard Black Cap Raspberry, being more extensively grown than any other variety. Price 3 for 25 cts., 12 for 85 cts., 50 for $\$ 2.75$, 100 for $\$ 5.00$.

\section{The Best Blackberry}

443 Snyder This popular hardy Blackberry

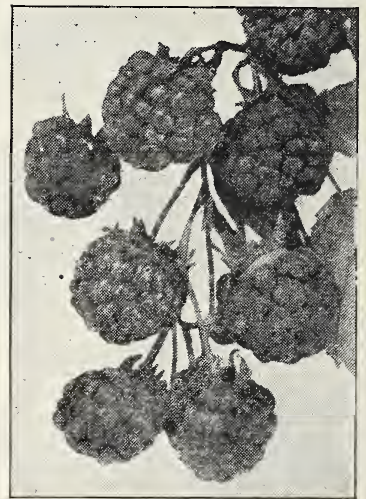

Early King Raspberry

largely grown than any other because of its extreme hardiness and dependability. Where other varieties often fail by winter killing. Snyder can always be depended on for an abundant crop. It is the Blackberry for every fruit grower. It is enormously productive, large, sweet and free from core. Price 2 for 25 cts., 12 for $\$ 1.00$, $\mathbf{5 0}$ for $\$ \mathbf{3 . 5 0}, \mathbf{1 0 0}$ for $\$ \mathbf{6 . 0 0}$.

\section{The Best Dewberry}

444 Lucretia The most largely grown of or market. It is a trailing species of Blackberry. It is earlier than the earliest Blackberry and larger than the largest of them. The trailing canes are hardy everywhere and free from disease. The fruit is superb, large and handsome. Jet black, sweet and melting. If you have never grown Dewberries try the Lucretia. Price 3 for 25 cts., 12

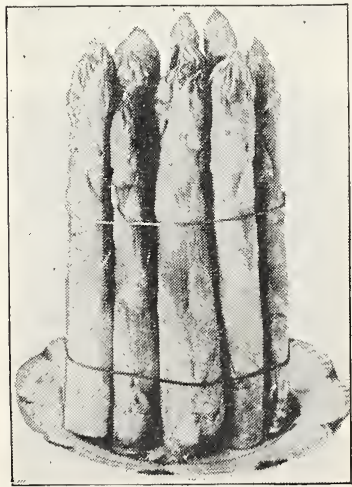
for 85 cts., 50 for $\$ 2.75,100$ for $\$ 5.00$.

\section{Asparagus Roots}

Columbian Mammoth Every home contain an Asparagus bed. Once planted it will require little care, and there is no other vegetable you can plant that will produce a greater quantity of desirable, nourishing food from the same space. An

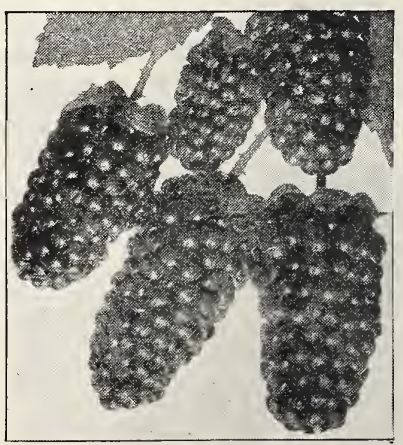

Snyder Blackberry ( 6 by 10 feet, requiring 50 roots to plant, when established will furnish a daily supply for three or four persons for two months or more each season. Plant roots and saveone or two years' time, as compared with planting seed. 44 Strong One - Year Roots 12 for 25 cents, 50 for 75 cents, 100 Tor $\$ 1.25$.

446 Extra Strong Two-Year Roots 12 for 40 cts., 50 for

\section{${ }_{447}$ Rhubarb Roots}




\section{QUATITS SEDDS}

THE TEMPLIN-CROCKETT-BRADLEY CO. 5700 DETROIT AVENUE, CLEVELAND, OHIO

Date

Gentlemen: I am enclosing \$___ for which send me the items herein ordered. Pack carefully and prepay all delivery charges. I understand that all seeds are to be of the highest quality obtainable, and if upon receipt and examination they are not as represented, they may be returned and money paid will be refunded.

NAME

Street No.

R.F.D.

Post Office

State

Read This $\begin{aligned} & \text { Besure to use this order } \\ & \text { blank when you send }\end{aligned}$ table and some flower seedo are offered in All vegetable and some flower seeds are offered in standard packets and in larger quantities. If you wish the garden, order in the left hand column, headed. "En. ter Standard Packets Wanted." If you wish any varieties in larger quantities, use the next column headed, "Enter Larger Quantities Wanted." In every case, be sure to extend the prices into the column headed. "Enter Total Value." Use pen can fill your order quicker and more accurately.
Total Value Vegetable Seeds Ordered from Page $1 \$$

Total Value Vegetable Seeds Ordered from Page $2 \$$

Total Value Flower Seeds Ordered from Page $3 \$$

Total Value Gladioli Bulbs Ordered from Page $3 \$$

Total Value Bulbs and Shrubs Ordered from Page $4 \$$

Money Order Enclosed for Total Amount........\$

\begin{tabular}{|c|c|c|c|}
\hline $\begin{array}{l}\text { Enter } \\
\text { thanderd } \\
\text { Packets } \\
\text { Wanted }\end{array}$ & $\begin{array}{c}\text { Enter } \\
\text { Lararer } \\
\text { Quantities } \\
\text { Wanted }\end{array}$ & QUALITY VEGETABLE SEEDS & $\begin{array}{l}\text { Enter } \\
\text { Tota } \\
\text { Vallue }\end{array}$ \\
\hline & & 1 Asparagus $\begin{array}{l}\text { Mammoth Colimmian } \\
\text { Pkt. } 3 \text { cts. Oz. Pkg } 10 \text { cts. }\end{array}$ & \\
\hline & & 2 Bush Bean Burpec's Stringless. & \\
\hline & & 3 Bush Bean Bountiful. ${ }^{1 / 1}$ Bib. pkt.T2c. & \\
\hline & & 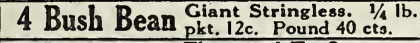 & \\
\hline & & 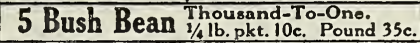 & \\
\hline & & 6 Bush Bean $\begin{array}{l}1 \text { mproved Golden Wax. } \\
1 / 4 \mathrm{lb} \text {. pkt. } 10 \mathrm{c} \text {. Pound } 35 \mathrm{c} \text {. }\end{array}$ & \\
\hline & & 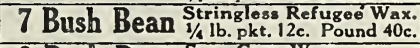 & \\
\hline & & 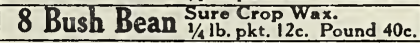 & \\
\hline & & 9 Bush Bean $\begin{array}{l}\text { New Wobber Wax. } \\
1 / 4 \text { lb. pkt. 12c. Pound } 40 \text { c. }\end{array}$ & \\
\hline & & 10 Pole Bean $\begin{array}{c}\text { Kentucky Wonder. } \\
1 / \mathrm{s} 1 \mathrm{~b} \text {. pkt.12c. Pound } 40 \mathrm{c} \text {. }\end{array}$ & \\
\hline & & 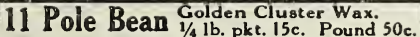 & \\
\hline & & 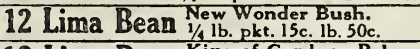 & \\
\hline & & 13 Lima Bean King of Garden. Pole. & \\
\hline & & 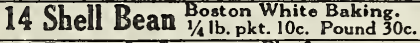 & \\
\hline & & 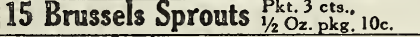 & \\
\hline & & 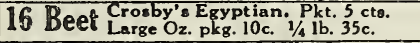 & \\
\hline & & 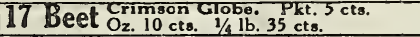 & \\
\hline & & 18 Beet $\begin{array}{l}\text { Detroit Dark Red. Pkt. } 5 \text { cts. } \\
\text { Oz. } 10 \text { cts. } 1 / 4 \mathrm{lb} .35 \mathrm{cts} . \\
\end{array}$ & \\
\hline & & 19 Beet & \\
\hline & & 20 Mangel Wurzel ${ }_{1 / 4 \text { ib. }}^{O_{2} \text { pkt. } 25 \text { c. Lb. } 90 c \text { c, }}$ & \\
\hline & & 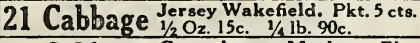 & \\
\hline & & 22 Cabbage Copenhagen Market. Pkt. & \\
\hline & & 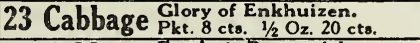 & \\
\hline & & 24 Cabbage Fottler's $\begin{array}{l}\text { Funswick. } \\
\text { Pkt. } 3 \text { cts. } 1 / 2 \text { oz. } 10 \text { cts. }\end{array}$ & \\
\hline & & 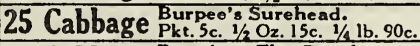 & \\
\hline & & 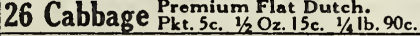 & \\
\hline & & 27 Cabbage $\begin{array}{l}\text { Danish Ballhead. Pkt. 10c. } \\
1 / 2 \text { Oz. } 25 \text { c. } 1 / 6 \text { lb. } \$ 1.25 .\end{array}$ & \\
\hline & & 28 Cabbage Prumhoad Savoy $_{\text {Pkt. } 3 \text { cts. } 1 / 2 \text { Oz. io cto. }}$ & \\
\hline & & $\begin{array}{l}29 \text { Cabbage Red Dutch Pickling. } 10 \text { Pkt. } 5 \text { cts. 1/4 Oz. pkg. } 10 \text { cto. } \\
\end{array}$ & \\
\hline & & 30 Pe-Tsai Pkt. 5 cts. $1 / 4$ Oz. 10 ct. & \\
\hline & & $\leftarrow$ Enter Totals Here $\Rightarrow$ & \\
\hline
\end{tabular}

\begin{tabular}{|c|c|c|c|}
\hline \multicolumn{4}{|c|}{ QUALITY VEGETABLE SEEDS } \\
\hline & & 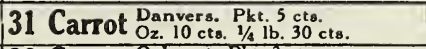 & \\
\hline & & 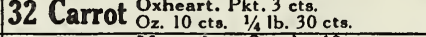 & \\
\hline & & 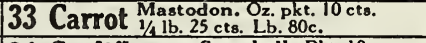 & \\
\hline & & 34 Cauliflower $\begin{array}{c}\text { Snowball. Pkt. 10c. } \\
1 / 8 \mathrm{Oz} .25 \mathrm{c} . \mathrm{Oz} . \$ 1.50 .\end{array}$ & \\
\hline & & $\begin{array}{l}35 \text { Celery Golden Seli Blanching } \\
\text { Pkt. } 8 \text { cto. } 1 / 4 \text { Oz. pkg. } 15 \text { cts. }\end{array}$ & \\
\hline & & 36 Celery $\begin{array}{l}\text { New Easy Blanching. } \\
\text { Pkt. 10 cts. } 1 / 4 \text { Oz. pkg. } 20 \text { cts. }\end{array}$ & \\
\hline & & 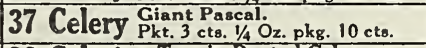 & \\
\hline & & 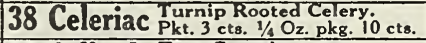 & \\
\hline & & 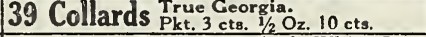 & \\
\hline & & 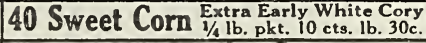 & \\
\hline & & 41 Sweet Corm $\begin{array}{c}\text { Golden Bantam. } \\
1 / 1 \text { b. pkt. } 10 \text { cts. ib. } 35 \text { c. }\end{array}$ & \\
\hline & & $\begin{array}{l}42 \text { Sweet Corn } \\
\text { DeLue's } 8 \text { Golden Giant. } \\
1 / 4 \text { lb. pkt. } 15 \text { cts. lb. } 50 \mathrm{c} \text {. }\end{array}$ & \\
\hline & & 43 Sweet Corn $\begin{array}{l}\text { Black Mexican. } \\
1 / 4 \mathrm{lb} \text {. pkt. } 10 \mathrm{cts} \text {. lb. 35c. }\end{array}$ & \\
\hline & & 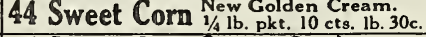 & \\
\hline & & 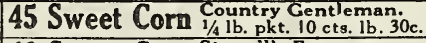 & \\
\hline & & 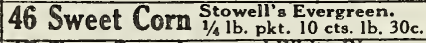 & \\
\hline & & 47 Pop Corn $\begin{array}{l}\text { Improved White Rice. } \\
1 / 4 \mathrm{~b} \text {. pkt. } 10 \mathrm{cts} \text {. Pound } 35 \text {. }\end{array}$ & \\
\hline & & 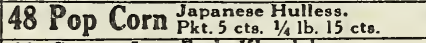 & \\
\hline & & 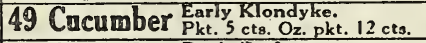 & \\
\hline & & 50 Cucumber Davis Perfect. & \\
\hline & & 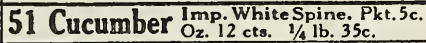 & \\
\hline & & 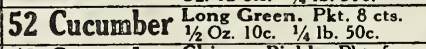 & \\
\hline & & 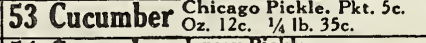 & \\
\hline & & 54 Cucumber $\begin{array}{l}\text { Jersey Pickle. } \\
\text { Pkt. } 3 \text { cts. Oz. pkg. } 10 \text { cts. }\end{array}$ & \\
\hline & & 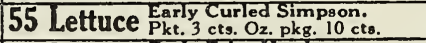 & \\
\hline & & 56 Lettuce $\begin{array}{l}\text { Early Prizo Head. } \\
\text { Pkt. } 5 \text { cts. } 1 / 2 \text { Oz. pkg. } 10 \text { cts. }\end{array}$ & \\
\hline & & 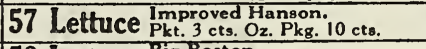 & \\
\hline & & 58 Lettuce $\begin{array}{l}\text { Big Boston. } \\
\text { Pkt. } 5 \text { cts. Oz. pkg. } 15 \text { cts. }\end{array}$ & \\
\hline & & 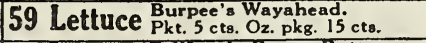 & \\
\hline & & 60 Leftuce Callifornia Cream Butter. & \\
\hline & & $\leftarrow$ Enter Totals Here $\Rightarrow$ & \\
\hline
\end{tabular}

Total Value Vegetable Seeds Ordered From This Page \$ 


\section{QUALITY VEGETABLE SEEDS}

\begin{tabular}{|c|c|c|c|c|c|c|c|}
\hline $\begin{array}{c}\text { Enfer } \\
\text { Standard } \\
\text { Dackets } \\
\text { Wanted }\end{array}$ & $\begin{array}{c}\text { Enter } \\
\text { Larger } \\
\text { Quantities } \\
\text { Wanted }\end{array}$ & NAMES OF VARIETIES & $\begin{array}{l}\text { Enter } \\
\text { Total } \\
\text { Value }\end{array}$ & $\begin{array}{c}\text { Enter } \\
\text { Standard } \\
\text { Packets } \\
\text { Wanted }\end{array}$ & $\begin{array}{c}\text { Enter } \\
\text { Larger } \\
\text { Quantities } \\
\text { Wanted }\end{array}$ & NAMES OF VARIETIES & $\begin{array}{l}\text { Enter } \\
\text { Total } \\
\text { Value }\end{array}$ \\
\hline & & $\begin{array}{l}1 \text { Lettuce New York Cabbage. } \\
\text { Pke. } 8 \text { c. } 1 / 2 \text { oz. pkg. } 15 \text { c. } \\
\end{array}$ & & & & 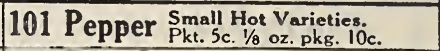 & \\
\hline & & 62 Lettuce Cos, Romaine or Celery. & & & & 102 Pumpkin Sugar Pie. & \\
\hline & & 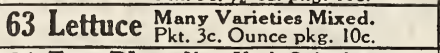 & & & & 103 Pumpkin Tennessee Sweet Potato. & \\
\hline & & 64 Egg Plant New York Spineless. ${ }_{\text {Pkt. 5c. 1/8 oz. 10c. Oz. 50c. }}$ & & & & 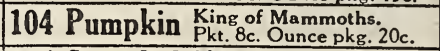 & \\
\hline & & 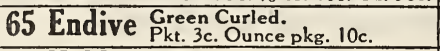 & & & & 105 Squash Golden Custard. & \\
\hline & & 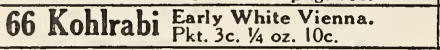 & & & & 106 Squash Early Summer Crookneck. & \\
\hline & & 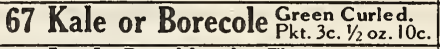 & & & & 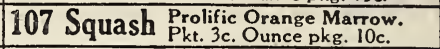 & \\
\hline & & 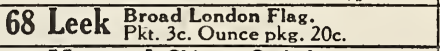 & & & & 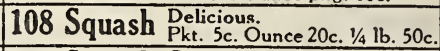 & \\
\hline & & 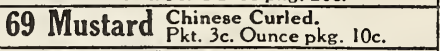 & & & & 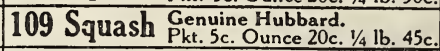 & \\
\hline & & 70 Muskmelon Extra Early Knight. 3 Pkt. 10c. Oz.20c. $1 / 4 \mathrm{lb} .75$ c. & & & & 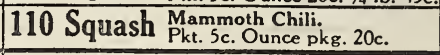 & \\
\hline & & 71 Muskmelon Famous Honey Dew.joc. & & & & 111 Salsify Vegetable Oyster. $15 \mathrm{c}$. & \\
\hline & & 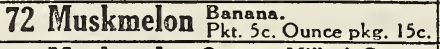 & & & & 112 Radish Earliest Scarlet Globe ${ }_{\text {Pkt. 5c. Oz.pkg.10c.1/4 ib. 35c. }}$ & \\
\hline & & 73 Muskmelon Osage or Miller's Cream. & & & & 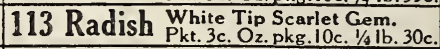 & \\
\hline & & 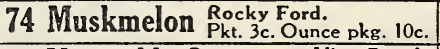 & & & & 114 Radish Crimson Giant. 12 c. 1/4 lb. 40c. & \\
\hline & & 75 Vegetable Orange $\stackrel{\text { or Vine Peach. }}{\text { Pkt. 5c. }}$ & & & & 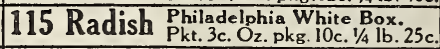 & \\
\hline & & 76 Watermelon Cole's Extra Early. 10 c. & & & & 116 Radish French Breakfast. $1 /$ lb. 35c. & \\
\hline & & 77 Watermelon Golden Honey. ${ }_{\text {Pkt. 5c. Ounce pkg. 10c. }}$ & & & & 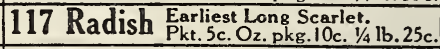 & \\
\hline & & 78 Watermelon $\begin{array}{l}\text { Halbert's Hone y. } \\
\text { Pkt.5c.Oz.10c.1/4 lb.30c. }\end{array}$ & & & & 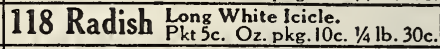 & \\
\hline & & 79 Watermelon Tom Watson. ${ }_{\text {Pkt. 5c. Oz.10c. 1/4 lb. 30c. }}^{\text {To }}$ & & & & 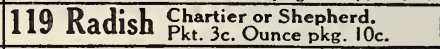 & \\
\hline & & 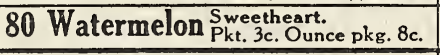 & & & & 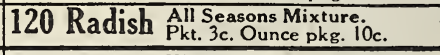 & \\
\hline & & 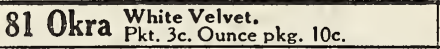 & & & & 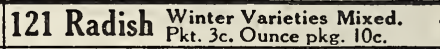 & \\
\hline & & 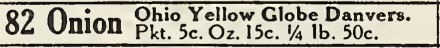 & & & & 122 Radish Japanese Varieties. & \\
\hline & & $\begin{array}{l}3 \text { Onion Large Red Wethersfield. } \\
\text { Pkt. } 5 \text { c. Oz. } 15 \text { c. } 1 / 4 \text { lb. } 50 \text { c. }\end{array}$ & & & & 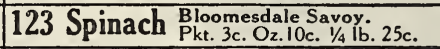 & \\
\hline & & $\begin{array}{l}4 \text { Onion Mammoth Silver King. } \\
\text { Pkt. 8c. Ounce pkg. 20c. }\end{array}$ & & & & 124 Spinach New Zealand. ${ }_{\text {Pkt. 5c. Ounce pkg. 15c. }}$ & \\
\hline & & 85 Onion Prizetaker. 2 Pkt. 5c. Oz. 20c. $1 / 4$ lb. 65 c. & & & & 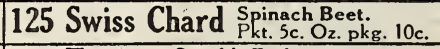 & \\
\hline & & 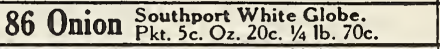 & & & & 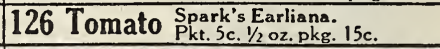 & \\
\hline & & 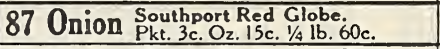 & & & & 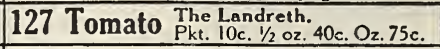 & \\
\hline & & Onion Seed for Growing Sets & & & & 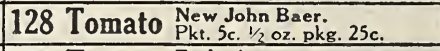 & \\
\hline & & $\begin{array}{l}\text { 87a Yellow Special price, } 1 / 4 \text { lb. } 35 \mathrm{c} . \\
\text { Pound } \$ 1.25 \text {. }\end{array}$ & & & & 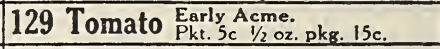 & \\
\hline & & $\begin{array}{l}\text { 87b Red Special price, } 1 / 4 \mathrm{lb} .35 \mathrm{c} . \\
\text { Pound } \$ 1.25 \text {. }\end{array}$ & & & & 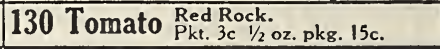 & \\
\hline & & 88 Onion, Pickling Early Silver Bell. & & & & 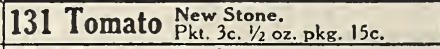 & \\
\hline & & 89 Pea Extra Early Alaska. $1 / 4 \mathrm{lb}$. pkt. 10c. Pound 35c. & & & & 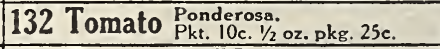 & \\
\hline & & 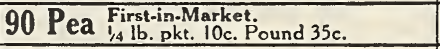 & & & & 133 Tomato Small Preserving. & \\
\hline & & 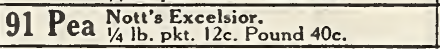 & & & & 134 Turnip Extra Early Milan. $1 / 1$ lb. 40c. & \\
\hline & & $\begin{array}{l}92 \text { Pea Thomas Laxton. } \\
1 / 4 \mathrm{lb} \text {. pkt. } 12 \mathrm{c} \text {. Pound } 40 \mathrm{c} \text {. }\end{array}$ & & & & $\begin{array}{l}135 \text { Turnip Purple Top Strap Leaf. } \\
\text { Pkt.3c. Oz.pkg.10c. 1/4lb. 25c. }\end{array}$ & \\
\hline & & 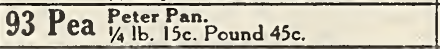 & & & & 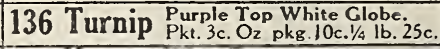 & \\
\hline & & 94 Pea Alderman $1 / 4$ lb. pkt. i2c. Pound 40 c. & & & & 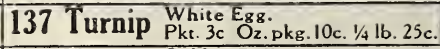 & \\
\hline & & $\begin{array}{l}95 \text { Pea Mammoth Melting Sugar. } \\
1 / 4 \mathrm{lb} \text {. pkt. } 12 \mathrm{c} \text {. Pound } 40 \mathrm{c} \text {. }\end{array}$ & & & & 138 Turnip Golden Ball. ${ }_{\text {Pkt. 3c. Oz.pkg. 10c 1/4 lb. 25c. }}$ & \\
\hline & & 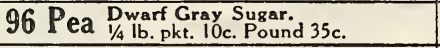 & & & & 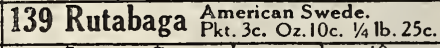 & \\
\hline & & 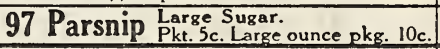 & & & & 140 Lawn Grass Large package $10 c$ Pound 45 c. 5 lb. $\$ 2.00$. & \\
\hline & & 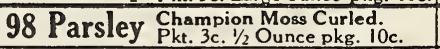 & & & & 141 Pure White Clover Pound $85 \mathrm{c}$. & \\
\hline & & 99 Parsley Hamburg Turnip Rooted. & & & & 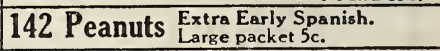 & \\
\hline & & 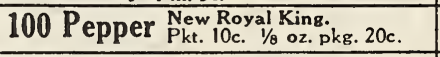 & & & & 143 Sunflower For Poultry Food. ${ }_{\text {Pkt. } 5 c .1 / 4 \text { lb. } 10 \text { c ib. } 30 \text { c. }}$ & \\
\hline & & $\leftarrow$ Enter Totals Here $\Rightarrow$ & & & & $\leftrightarrow$ Enter Totals Here $\Rightarrow$ & \\
\hline
\end{tabular}

Carefully selected for the convenience of busy people. A well balanced assortment for a complete Home Carden. Every variety one of the best in its respective class.

For full information see page 3 of catalog. No changes in varieties can be allowed.

Home Garden Seed Collection-TheseTwenty-six Full Size Packets for $\$ 1.00$ 


\section{QUALITY FLOWER SEEDS}

\begin{tabular}{|c|c|c|}
\hline 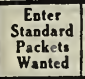 & 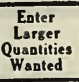 & NAMES OF VARIETIES \\
\hline & & $\begin{array}{l}151 \text { Aster Queen of the Market. } \\
\text { Pkt. } 5 \text { cto. } 1 / 8 \text { ounce, } 15 \text { cts. }\end{array}$ \\
\hline & & 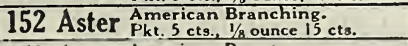 \\
\hline & & $\begin{array}{l}153 \text { Aster American Beauty. } \\
\text { Pkt. } 10 \text { cts. } 1 / 8 \text { ounce, } 25 \text { cts. }\end{array}$ \\
\hline & & $\begin{array}{l}154 \text { Aster Giant Branching Comet. } \\
\text { Pkt. } 10 \text { cts. } 1 / 8 \text { ounce } 25 \text { cts. }\end{array}$ \\
\hline & & $\begin{array}{l}155 \text { Aster New Giant Crego } \\
\text { Pkt. } 10 \text { cts. } 1 / 8 \text { ounce } 20 \text { cts. }\end{array}$ \\
\hline & & 156 Aster $\begin{array}{l}\text { New Kings. } \\
\text { Pkt. } 10 \text { cts., } 1 / 8 \text { ounce } 25 \text { cts. }\end{array}$ \\
\hline & & 157 Aster $\begin{array}{l}\text { Ostrich Plume. } \\
\text { Pkt. } 10 \text { clta. } 1 / 8 \text { ounce } 25 \mathrm{cts} .\end{array}$ \\
\hline & & 158 Aster One packet each of above \\
\hline & & $\begin{array}{l}159 \text { Aster Extra Quality Mixed. } \\
\text { Pkt. } 10 \mathrm{cts} \text {. } 1 / \mathrm{s} \text { ounce } 20 \mathrm{cts} \text {. }\end{array}$ \\
\hline & & 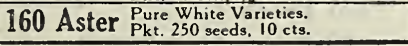 \\
\hline & & 161 Aster $\begin{array}{l}\text { Delicate Flesh Pink. } \\
\text { Pkt. } 250 \text { seeds, } 10 \mathrm{cts} \text {. }\end{array}$ \\
\hline & & $\begin{array}{l}162 \text { Aster } \begin{array}{l}\text { Light Blue and Lavender. } \\
\text { Pkt. } 250 \text { seeds, } 10 \text { cts. }\end{array} \\
\end{array}$ \\
\hline & & 163 Alyssum $\frac{L}{\text { tetle Gem }}$ Cets. $1 / 4$ ounce 10 cts. \\
\hline & & $\begin{array}{l}164 \text { Amaranthus Love Lies B Beeding. } \\
\text { Pkt. } 500 \text { seeds, } 3 \text { cts. }\end{array}$ \\
\hline & & 165 Baby's Breath Cypsophila. 3 Pkt 800 seds, 3 cts. \\
\hline & & $\begin{array}{l}166 \text { Blanket Flower Gaillardia. } \\
\text { Pkt. } 200 \text { seeds. 3c. }\end{array}$ \\
\hline & & 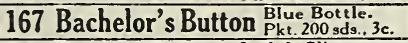 \\
\hline & & 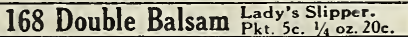 \\
\hline & & $\begin{array}{l}169 \text { Carnation Double Marguerite. } \\
\text { Pkt. } 250 \text { seeds, } 10 \text { cts. }\end{array}$ \\
\hline & & $\begin{array}{l}170 \text { Calendula Scotch Marisold } \\
\text { Pkt. } 100 \text { large seeds, } 3 \text { cts. }\end{array}$ \\
\hline & & 171 Calif. Poppy $\begin{array}{c}\text { Eschscholtzia. } \\
\text { Pkt. } 3 \text { cts. } 1 / 1 / \text { oz. } 15 c .\end{array}$ \\
\hline & & $\begin{array}{l}172 \text { Candytuft All Colors Mixed. } \\
\text { Pkt. } 3 \text { cts.. } 1 / 4 \text { ounce } 10 \mathrm{c} \text {. }\end{array}$ \\
\hline & & 173 Chinese Wool Flower Celosia \\
\hline & & 174 Calliopsis or Coreopsis. $\begin{array}{c}\text { or } \\
\text { Pkt. } 500 \text { seds, } 3 \text { cts. }\end{array}$ \\
\hline & & $\begin{array}{l}175 \text { Ostrich Plume Celosia Magnifica. } \\
\text { Pkt. } 400 \text { seeds. Scts. }\end{array}$ \\
\hline & & 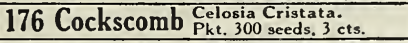 \\
\hline & & $\begin{array}{l}177 \text { China Pinks Dianthus Mixed. } \\
\text { Pkt. } 5 \text { cts.o } 1 / 8 \text { oz } 15 c .\end{array}$ \\
\hline & & 178 Cosmos $\begin{array}{l}\text { Giant Fk. } 5 \text { cts. } .1 / 4 \text { ounce } 15 \text { cts. } \\
\text { Pling }\end{array}$ \\
\hline & & 179 Everlastings Starge packet 10 cto. \\
\hline & & 180 Dahlia New Sing to 75 seeds. 3 cts. \\
\hline & & 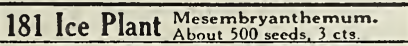 \\
\hline & & 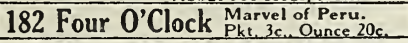 \\
\hline & & 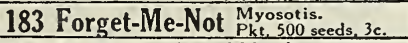 \\
\hline & & 184 Larkspur Annual Mixed Pkt.300 seeds, 5 ctg. \\
\hline & & 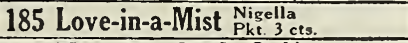 \\
\hline & & 186 Mourning Bride $\begin{array}{c}\text { Scabiosa. } \\
\text { Pkt. } 3 \text { cts. }\end{array}$ \\
\hline & & 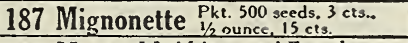 \\
\hline & & $\begin{array}{l}188 \text { Marigold African and French. } \\
\text { Pkt. } 150 \text { seeds, } 3 \text { cts }\end{array}$ \\
\hline & & 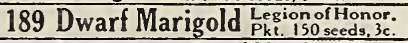 \\
\hline & & 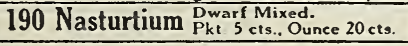 \\
\hline & & $\leftarrow \quad$ Enter Totals Here $\Rightarrow$ \\
\hline
\end{tabular}

\begin{tabular}{|c|c|}
\hline \multicolumn{2}{|c|}{ 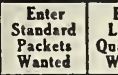 } \\
\hline & \\
\hline & \\
\hline & \\
\hline & \\
\hline & \\
\hline & \\
\hline & \\
\hline & \\
\hline & \\
\hline & \\
\hline & \\
\hline & \\
\hline & \\
\hline & \\
\hline & \\
\hline & \\
\hline & \\
\hline & \\
\hline & \\
\hline & \\
\hline & \\
\hline & \\
\hline 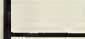 & \\
\hline & \\
\hline & \\
\hline & \\
\hline & \\
\hline & \\
\hline & \\
\hline & \\
\hline & \\
\hline & \\
\hline & \\
\hline & \\
\hline
\end{tabular}

NAMES OF VARIETIES

191 Nasturtium $\begin{gathered}\text { Tall or Climbing } \\ \text { Pkt. } 3 \text { cts., Ounce }\end{gathered}$

192 Nasturtium $\begin{gathered}\text { New Ivy L Leaved. } \\ \mathrm{Pkt} .8 \mathrm{cts} s, 1 / 2 \text { ounce } 15 \mathrm{c} \text {. }\end{gathered}$

193 Nasturtium New Tall Variegated.

194 Nasturtium Lilliput Dwarf.

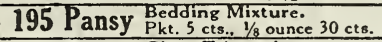

196 Pansy Ciant Trimardeau- 40 cts.

197 Pansy Gkt.15c..2 pkts 25 c...5 pkts. 50 c.

198 Pansy Giant Exhibition.

199 Petunia Hybrida Mixed.

200 Petunia $\begin{aligned} & \text { Rosy Morn } \\ & \text { Pkt. } 250 \text { seds. } 10 \mathrm{cts} .\end{aligned}$

201 Petunia Howard Star. 10 cts.

202 Phlox Drummonondii Mined Codors.

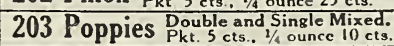

204 Painted Daisy Annual Chrysan-

205 Portulaca Rose Moss Singile Mixed.

206 Portulaca Fint. 500 seeds, 10 cts.

207 Snapdragon Antirrhimum Mixed.

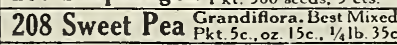

209 Sweet Pea $\begin{gathered}\text { Sencer or Orchid Flow- } \\ \text { ering. Pkt. 8c. } 1 / 2 \text { oz. Isc. }\end{gathered}$

210 Sweet Pea Extra. Quality Spencer.

211 Sweet Pea Pwarf Baby Cupid.

212 Stocks $\begin{aligned} & \text { Ten Wekek. Choice Mixed. } \\ & \text { Pkt. } 5 \text { cts. }\end{aligned}$

213 Sweet William New Annual.

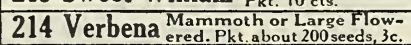

215 Zinnia $\begin{gathered}\text { Ciant Flowering } \\ \text { All colors. Pkt. } 10 \text { cts. }\end{gathered}$

216 Zinnia Elegans. Double Mixed.

\section{CLIMBING VINES}

217 Balloon Vine Love-in-a-Puff. Pk

218 Cardinal Climber Cypress Vine.

219 Cypress Vine Pkt.40 to o 0 semeds 3 sets.

220 Hyacinth Bean Dolichos. Fit. 40

221 Ipomoea Japanese Morning Glory.

222 Morning Glory ${ }_{3 \mathrm{cts} .0 \mathrm{O}_{z} \text {. Pkg. } 12 \mathrm{cts} \text {. }}^{\text {All }}$

HARDY PERENNIALS

223 Canterbury Bell $\begin{gathered}\text { or Campanula. } \\ \text { Rkt. } 500 \text { sds } 3 \mathrm{cts} \text {. }\end{gathered}$

224 Foxglove or Pirt. 500 to 0600 seds. $3 c t s$.

225 Hollyhock Lart.about S0 sceds. 5 cts.

226 Shasta Daisy Pure White.

227 Sweet May Pink Sink. 200 ods.5 scts.

228 Sweet William Many Varieciestixixed.

$\leftarrow$ Enter Totals Here $\rightarrow$

Total Value Flower Seeds Ordered From This Page \$

\section{A Million Gladioli Bulbs at Bargain Prices}

\section{Best Six New Gladioli}

301 Mrs. Frank Pendleton ${ }_{4 \text { for }}^{\text {Eack. }} 30 \mathrm{c}$.

302 Niagara $\begin{gathered}\text { Cream Yellow } \\ \text { Each } 8 \text { cts., } 4 \text { for } 30 \text { cts. }\end{gathered}$

303 Panama Best Lively Pink.

304 Peace Large White Very fine

305 Sche Each 7 cts. 4 lor 25 cets.

306 War Best Larree Blodod Red.

307 Set of 6 Best Gladioli for 40c

Twelve Popular Gladioli

308 America Delicate Peach-Blossom

309 Anna Wigman Canary Yellow

310 Augusta Forly White.

311 Baron Hulot Eark Velvel Blue.

Enter Totals Here
312 Brenchleyensis $\begin{aligned} & \text { Vermilion Scarlet. } \\ & \text { Each } 5 . .06 \text { for } 25 .\end{aligned}$

313 Halley Extra Earty, Salmón Pink.

314 Ida Van Bach Bariant Cards. 5 for 25 c..

315 Independence Rich Begenonia Pink

316 Mrs. Francis King 6 torc 25 ctis.

317 Primulinus Extra Early Yellow.

318 Princepine Scarlet. Whitite Bloctches.

319 Sulphur Queen Caach bc.. Yellow tor 25 e.

320 Set of 12 Popular Varieties Not Labeled, 50 cts.

Superfine Mixed Gladioli

321 1st Size $11 / 2$ tor $11 / 2$ inch ond up in dia

322 2nd Size 18 is tor $11 / 8$ inch diameter.

Total Value Gladioli Bulbs Ordered From This Page \$ 


\section{BULBS, ROSES, SHRUBS, SMALL FRUITS, ETC.}

\begin{tabular}{|c|c|c|c|c|c|}
\hline $\begin{array}{c}\text { Enter } \\
\text { Number } \\
\text { Wanted } \\
\text { ant }\end{array}$ & NAMES OF VARIETIES & $\begin{array}{l}\text { Enter } \\
\text { Total } \\
\text { Value } \\
\end{array}$ & $\begin{array}{c}\text { Enter } \\
\text { Number } \\
\text { Wanted }\end{array}$ & NAMES OF VARIETIES & $\begin{array}{l}\text { Enter } \\
\text { Total } \\
\text { Value }\end{array}$ \\
\hline & QUALITY DAHLIAS & & & 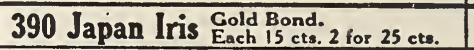 & \\
\hline & 330 Cockatoo Cactus Novelty. & & & 391 Japan Iris Mach 20 cts. & \\
\hline & 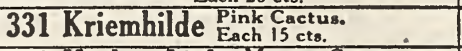 & & & $\begin{array}{l}392 \text { Japan Iris Purple and Gold. } \\
\text { Each } 15 \text { cts. } 2 \text { for } 25 \text { cts. }\end{array}$ & \\
\hline & 332 Harbor Light Mach is cts. & & & 393 Set of 3 Japan Iris for $45 c$. & \\
\hline & 333 Mrs. Cassatt New Pink Decorative. & & & $\begin{array}{l}394 \text { Delphinumm Eelladonna Grandifora } \\
\text { Each } 20 \mathrm{cts}, 3 \text { for } 50 \mathrm{cts} \text {. }\end{array}$ & \\
\hline & 334 Jack Rose Crimson Decorative. & & & $\begin{array}{l}395 \text { Lily of Valley } \\
50 \text { for } \$ 150.150 .100 \$ 2.75 \text { cor. }\end{array}$ & \\
\hline & 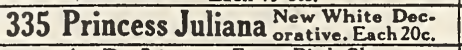 & & & 399 Mallow Marv. 1-Year ${ }_{12}^{20 \mathrm{c} \$ 1.50 \mathrm{c} .}$ & \\
\hline & 336 A. D. Livoni Extra Pink Show. & & & 400 Mallow Marv. 2-Year $\begin{array}{l}\text { Each } 35 \mathrm{~s} \text { c. } \\
3 \text { for } \$ 1.00 .\end{array}$ & \\
\hline & 337 Cuban Giant Mammoth Crimson & & & $\begin{array}{l}401 \text { Peony Duchesse do Nemours. } \\
\text { Each } 40 \text { cts. }\end{array}$ & \\
\hline & 338 White Swan Pure White Show. & & & 402 Peony Edulis Superba. & \\
\hline & 339 Bride Pure White Pompon. & & & 403 Peony Felix Crousse. & \\
\hline & 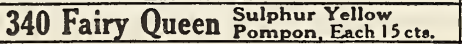 & & & 404 Set of 3 Best Peonies $\$ 1.25$. & \\
\hline & 341 Prince Charming Each 20 cts. & & & $\begin{array}{l}\text { HARDY ROSES } \\
\end{array}$ & \\
\hline & 342 Mrs. Keeling New Peony Dahlia. & & & 410 Frau K. Druschki ${ }_{\text {Each } 60 \text { cts. }}^{\text {Double }}$ & \\
\hline & 343 Set 13 Named Dahlias \$1.75. & & & 411 Gen'l Jacqueminot Double Red. & \\
\hline & 344 Choice Mixed Dahlias 6 i2 for $50 \mathrm{coc}$ 90. & & & 412 Paul Neyron Giant Double Pink. & \\
\hline & HARDY CHRYSANTHEMUMS & & & 413 Set of 3 H. P. Roses $\$ 1.60$. & \\
\hline & 345 Glory of 70 aks Everblooming. & & & 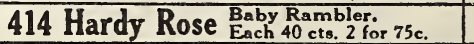 & \\
\hline & 34e Golden Climax Golden Yellow. & & & 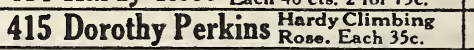 & \\
\hline & 347 Indian Chief Coppery Crimson. & & & 416 Excelsa Hardy Crimson Climber. & \\
\hline & 348 Old Homestead Rase-Pinks. & & & 417 Two Best Climbing Roses $65 c$. & \\
\hline & 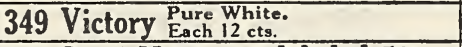 & & & HARDY SHRUBS & \\
\hline & 350 Set 5 Mums not labeled $50 c$. & & & 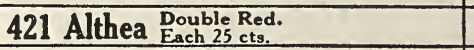 & \\
\hline & CANNA ROOTS & & & 422 Althea Doubble Whito. & \\
\hline & 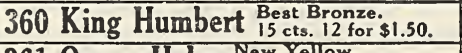 & & & 423 Barberry 150 for $\$ 8.00 .11 .25$. & \\
\hline & 361 Queen Helen $\begin{array}{c}\text { New Yellow. } \\
\text { cts. } 12 \text { for } \$ 1.50 .\end{array}$ & & & 424 Calycanthus Sweet Shrub. & \\
\hline & 362 Two Best Cannas for $25 \mathrm{cts}$. & & & 425 Deutzia $\begin{array}{l}\text { Pride of Rochester. } \\
\text { Each } 20 \text { cts. }\end{array}$ & \\
\hline & 363 Buttercup $12 \mathrm{cest}$ Pure Yellow. 5 for $5 \mathrm{coc}$. 1 for $\$ 1.25$. & & & 426 Forsythia Colden Chain. & \\
\hline & 364 Crimson Bedder $\begin{array}{l}\text { Best Red } \\
5 \text { for } 50 \text { c. } 12 \$ 1.25 .\end{array}$ & & & 427 Bush Honeysuckle ${ }_{2}^{\text {Lonicera }}$ r. Each $25 \mathrm{c}$. & \\
\hline & 365 Gladiator Yellow Spotted Red $\begin{array}{l}\text { Yed } \\
12 \mathrm{c} .5 \text { for } 50 \mathrm{c} \text {. } 12 \text { for } \$ 1.25 .\end{array}$ & & & 428 Hydrangea P. G. 15 year & \\
\hline & $\begin{array}{l}366 \text { Madam Crozy } \text { Gilt Edge Canna }_{12 \text { cts. } 12 \text { for } \$ 1.25 .} \\
\end{array}$ & & & 429 Hydrangea P. G. $\frac{2}{25}$ year & \\
\hline & 367 Venus $\begin{array}{l}\text { Rosy-P } \\
12 \text { cts. } 5 \text { for } \\
\end{array}$ & & & 430 Mock Orange 2 Each 25 cts. & \\
\hline & 368 Austria $\begin{array}{l}\text { Giant Orchid Canna } \\
12 c .5 \text { for } 50 \mathrm{cts} .12 \text { for } \$ 1.25 .\end{array}$ & & & $\begin{array}{l}431 \text { Snowberry } \\
\text { Symphoricarpos. } \\
2 \text { year each } 25 \text { cts. }\end{array}$ & \\
\hline & 3696 Bedding Cannas Labeled, 65 c. & & & 432 Spirea Anthony Water Waterer. 25 cts. 12 for $\$ 1.75$. & \\
\hline & 370 Set of 6 Cannas $\begin{array}{l}\text { Not Labeled, } \\
120 \mathrm{cor} 90 \mathrm{cts} .\end{array}$ & & & 433 Spirea Van Houttei 20 cts. 12 for $\$ 1.50$. & \\
\hline & MISCELLANEOUS BULBS & & & 434 Spirea 2 yecar plants. 30 cts. 12 for $\$ 2.50$. & \\
\hline & 371 Caladium $\begin{array}{c}\text { Elephant's Ear. } \\
\text { Medium bulb } 15 \text { cts. }\end{array}$ & & & 435 Weigela Rosea ${ }_{30}^{2}$ cts. & \\
\hline & 372 Caladium $\begin{array}{c}\text { Elephant's } \\
\text { Large bulb } 25 \text { Ear. }\end{array}$ & & & SMALL FRUITS & \\
\hline & 373 Cinnamon Vine $\begin{array}{c}\text { Climbing Vine. } \\
10 \mathrm{cts} .3 \text { for } 25 \mathrm{cts} .\end{array}$ & & & $\begin{array}{l}440 \text { Strawberry Gibson. } 12 \text { for } 40 \text { cts. } \\
50 \text { for } 85 \text { c. } 100 \text { for } \$ 1.50 \text {. }\end{array}$ & \\
\hline & 374 Hyacinth Candicans ${ }_{3}^{10}$ for 25 cts. & & & 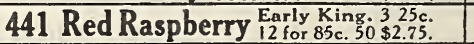 & \\
\hline & 375 Madeira Vine $\begin{array}{l}\text { Rapid Climber. } \\
10 \mathrm{css} .4 \text { for } 25 \mathrm{cts} .\end{array}$ & & & 442 Black Raspb'y Cumberland.325 $\begin{array}{l}\text { Cumb } \\
1285 \mathrm{c} .50 \text { for } \$ 2.75 .\end{array}$ & \\
\hline & 376 Oxalis $\begin{array}{l}\text { For Summer Borders. } \\
12 \text { for } 20 \mathrm{cts} .50 \text { for } 50 \mathrm{cts} .\end{array}$ & & & 443 Blackberry $\begin{array}{l}\text { Snyder } \$ 1.00 .50 \text { for } \$ 3.50 .12 \\
\text { for } \$ 2.12\end{array}$ & \\
\hline & 377 Dbl.Pearl Tuberose ${ }_{6}^{8 \mathrm{c}}$ for $40 \mathrm{cts} 15 \mathrm{c}$. & & & $\begin{array}{l}444 \text { Dewberry Lucretia. } 3 \text { for } 25 \mathrm{scts} \\
12 \text { for } 85 \mathrm{cts} .50 \text { for } \$ 2.75 \text {. }\end{array}$ & \\
\hline & 378 Mexican Tuberose 8 cts. 25 cts. & & & $\begin{array}{l}445 \text { Asparagus } 1 \text { vear. } 12 \text { for } 25 \text { corts } \\
50 \text { for } 75 \text {. } 100 \text { for } \$ 1.25 . \\
\end{array}$ & \\
\hline & 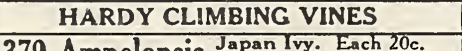 & & & $\begin{array}{l}446 \text { Asparagus } 2 \text { year. } 12 \text { for } 40 \text { cts. } \\
50 \text { for } \$ 1.00 \text {. } 100 \text { for } \$ 1.75\end{array}$ & \\
\hline & 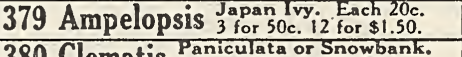 & & & 447 Rhubarb $\begin{array}{l}\text { year old roots } \\
4 \text { for } 25 \mathrm{cts} .12 \text { for } 65 \text { cts. }\end{array}$ & \\
\hline & $\begin{array}{l}380 \text { Clematis Panculata or Snowbank. } \\
\text { I year. } 20 \text { cts. } 3 \text { for } 50 \text { cts. }\end{array}$ & & & HARDY GRAPE VINES & \\
\hline & 381 Chinese Wisteria 15 Year Medium. & & & 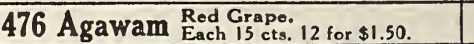 & \\
\hline & $\begin{array}{c}382 \text { Set of } 3 \text { Hardy Vines for } 50 c . \\
\text { HERBACEOUS ROOTS }\end{array}$ & & & 477 Concord 12 for $\$ 1.25 .100$ for $\$ 10.00$. & \\
\hline & 385 Iris Mrsar. M. Darwin, White. & & & 478 Moore's Early Back Grape $\begin{array}{c}\text { Black } 12 \text { for } \$ 1.50 \\
\end{array}$ & \\
\hline & 386 Iris Honorabbilis, Yellow. & & & 479 Niagara White Grape $\begin{array}{l}\text { Wach } 15 \text { cts. } 12 \text { for } \$ 1.50 \text {. } \\
\end{array}$ & \\
\hline & 387 Iris Mme Chereau Light blue: & & & 4804 Named Grape Vines 50c. & \\
\hline & $\begin{array}{l}388 \text { Iris Othello, Purple. } \\
\text { Each } 10 \text { cts. }\end{array}$ & & & 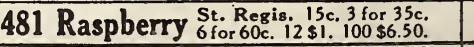 & \\
\hline & 389 Set of 4 lris Not Named 35c. & & & 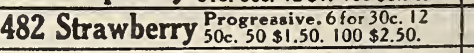 & \\
\hline & $\leftrightarrow$ Enter Totals Here $\quad \Rightarrow$ & & & $\leftarrow$ Enter Totals Here $\quad \rightarrow$ & \\
\hline
\end{tabular}


Name

P. 0 . State.

\title{
THE TEMPLIN-CROCKETT-BRADLEY CO.
}

\author{
5700 DETROIT AVENUE
}

CLEVELAND, OHIO' 



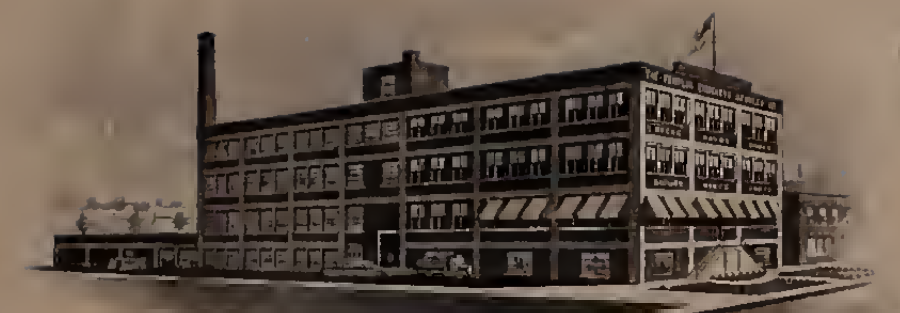

B L TEMPLIN, PAGGIDENT

G F BRADLEY, SECAETARY

\section{THETEMPUN:EROGKETTBRADLEY[0}

IMPORTERS GROWERS AND DEALERS

SEEDS, BULB S, ROOTS, SMALL FRUITS

\section{CleVELAND,OHIO:}

Season of 1921.

A Letter of Introduction

To Gardeners Everywhere:-

This will introduce to you our new catalog. In a year like this is starting out to be, a good seed catalog can help out your family income. It will show you what to plant so that your garden will be most productive. The seeds we offer have been named "QUALITY SEEDS'" for a definite reason, for quality is the foundation upon which our business has been built.

Have you noticed how easy it is to find what you want in this catalog? That is because everything is arranged in alphabetical order which is the natural order. And the order blank is made up so that it is not necessary for you to write out the names of the varieties which you wish to order. Just fill in your name and address and the quantity and price columns. This not only makes ordering easy for you but increases our speed and accuracy in filling orders.

At the bottom of page 9 reference has been made to the number of packets of seeds in that group which were sold by us last year. Similar notes are scattered through the catalog. This is pretty good evidence that our customers like our plan of listing only the leading varieties and also like our service and the quality of our seeds. We know that you too will be well pleased with your gardening efforts if you use our seeds.

Our custom is to ship seeds as soon as the order arrives and if bulbs and shrubs are ordered too, to hold up that part of the order until danger of freezing has passed. The stock will then reach you in first-class condition. Will you make up your order now, while it is fresh in your mind?

GFB.B.

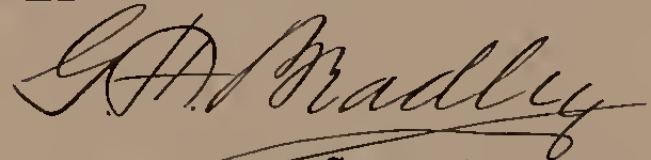
Secretary. P.S. If you wish us to make a seed selection for you, place an $X$ opposite this paragraph, wrap a dollar up in this letter, mail it back to us and we will send our big DOLLAR HOME GARDEN SEED COLLECTION. B. 


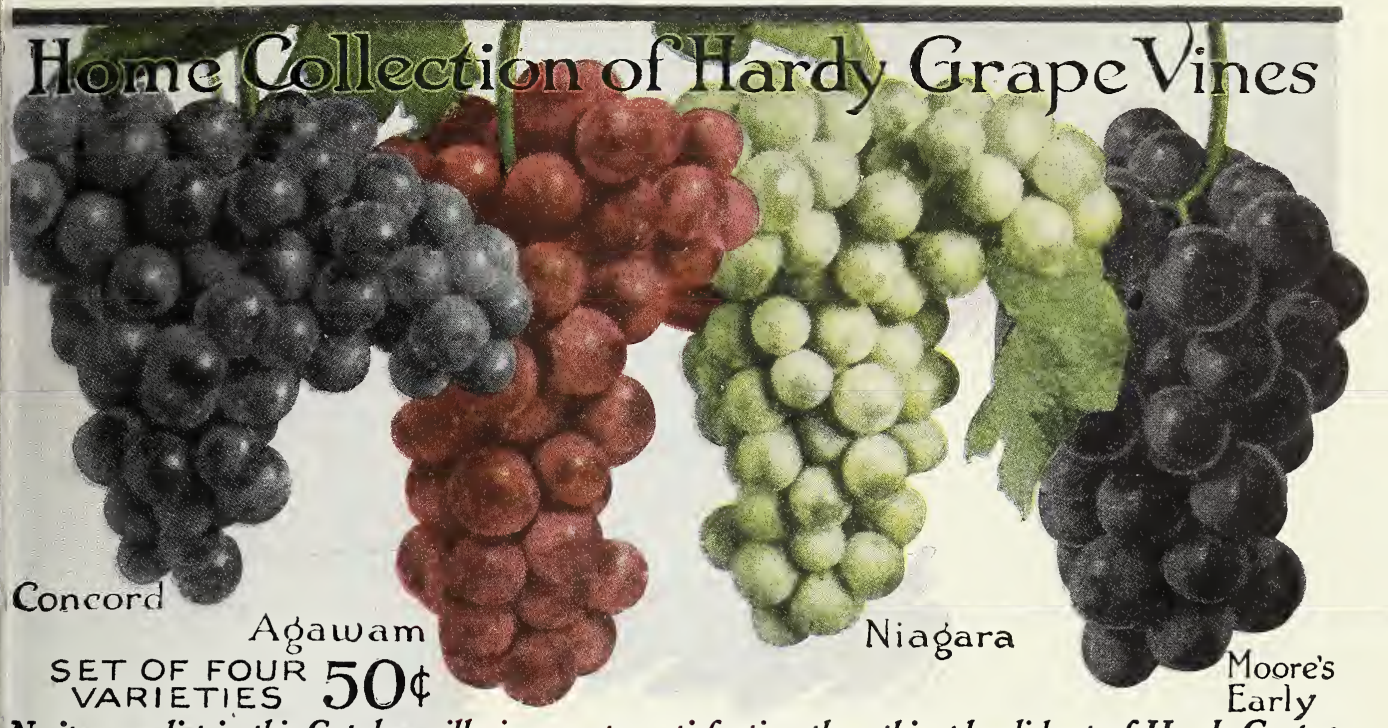

No item we list in this Catalog will give greater satisfaction than this splendid set of Hardy Grapes. Every home, if only on a city lot, can find room to plant them.

476 Agawam Berries large, on large compact bunches. Eyerybody should grow this variety. $15 \mathrm{cts} ., 12$ for $\$ 1.50$.

477 Concord The best-known grape. Success everywhere.

478 Moore's Early Large black berries, medium quality. Always dependable. 15 cts., 12 for $\$ 1.50$.

480 Strong, well-rooted, one-year-old wines, the set of 4 for 50 cts., postpaid and guaranteed.

\section{New Everbearing Raspberry}

1481 St. Regis A splendid new berry that is well worthy a place in every garden. A genuine, practical, profitable, productive, perpetual bearing variety. It produces an abundant main crop like the common varieties.

The old canes continue to produce fruit until middle of August, when they should be removed to make room for the young canes, which are already beginning to ripen fruit, continuing in increasing quantities until last of October. The berries are bright crimson, of good size and excellent quality. Strong, well-rooted plants. Price 15 cts., 3 for 35 cts., 6 for 60 cts., 12 for $\$ 1.00,100$ for $\$ 6.50$.

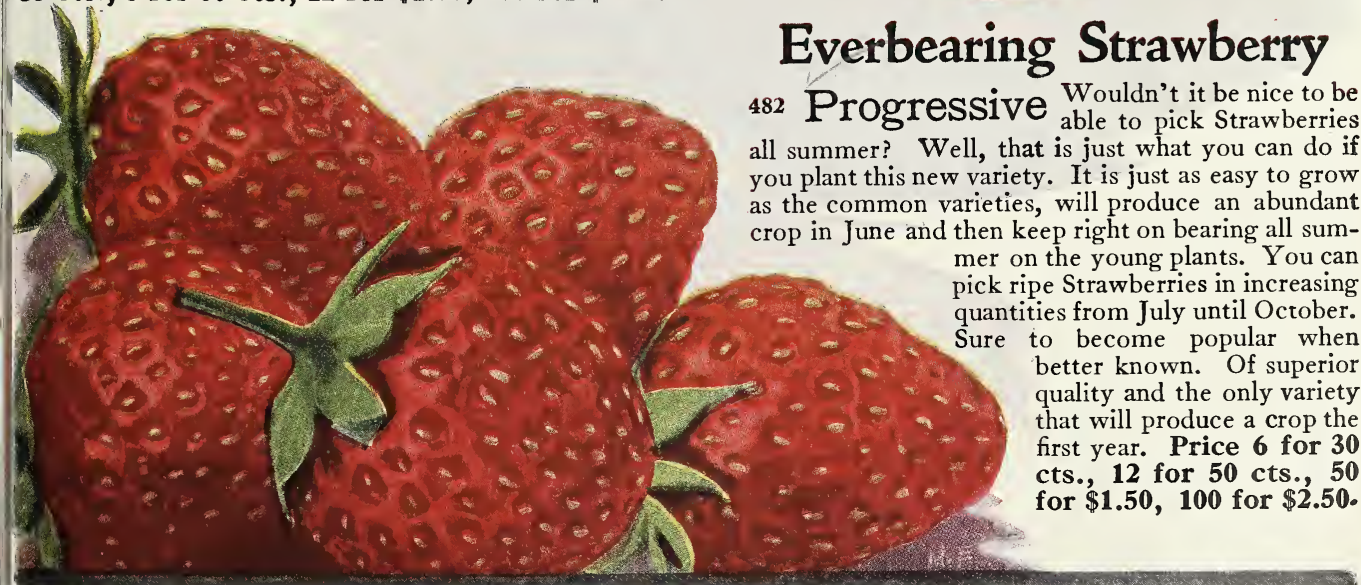




\section{Butbs,Roots, Smatu frutts}

MEHAN'S
AILOOW
ARVELS

(HARDY HIGISCUS)
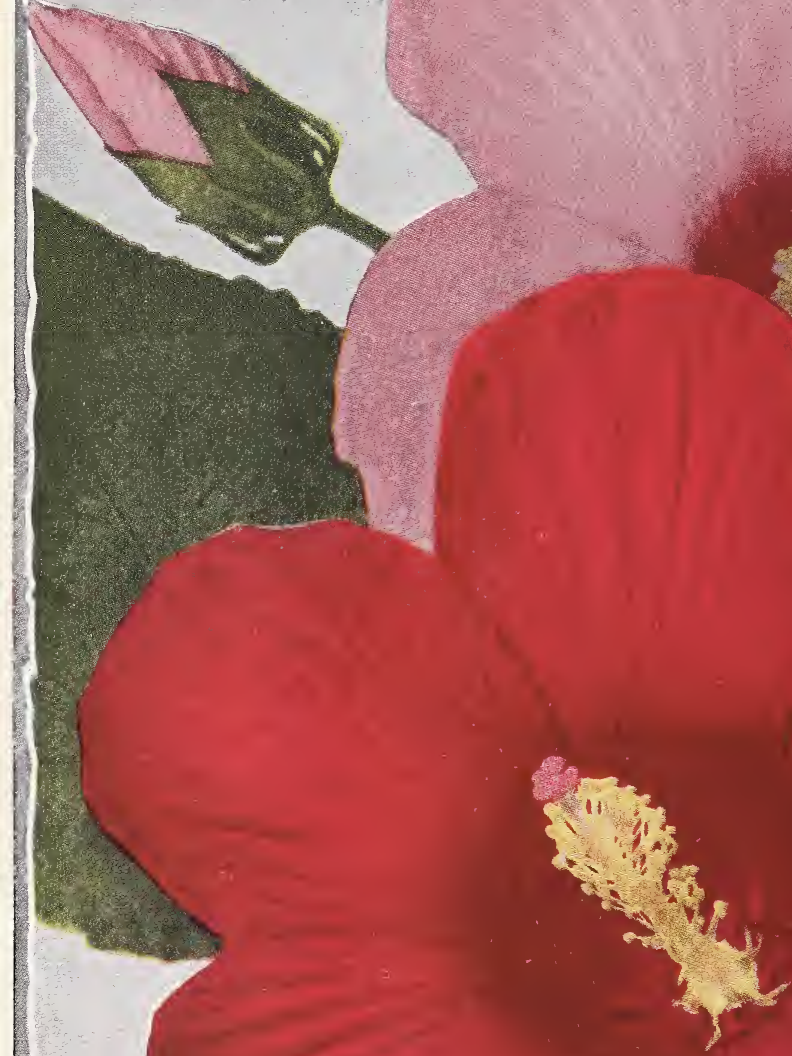

PRICE

One-year-old dormant Roots, guaranteed to bloom this year.

20 cts., 3 for 50 cts. 12 for $\$ 1.50$

Extra-strong two-year Roots. 35 cts., 3 for $\$ 1$

FOR DESCRIPTION SEE PAGE 22

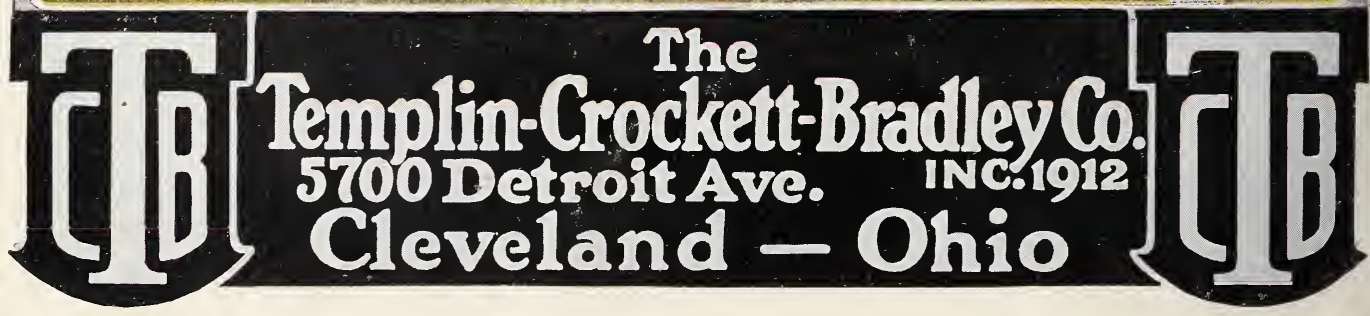

